MONOGRAPHS IN THE ECONOMICS OF DEVELOPMENT

No. 14

\title{
Social Characteristics of \\ The People of Karachi
}

IMTIAZUDDIN HUSAIN

MOHAMMAD AFZAL

SYED AMJAD ALI BAHADUR RIZVI

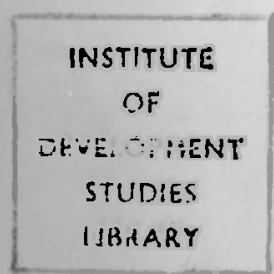

October 1965

PAKISTAN INSTITUTE OF DEVELOPMENT ECONOMICS

Old Sind Assen:bly Building

Bunder Ro :d, Karachi

(Pakistan) 


\title{
PAKISTAN INSTITUTE OF DEVELOPMENT ECONOMICS
}

\author{
Old Sind Assembly Building \\ Bunder Road, Karachi-1 \\ (Pakistan)
}

The Institute carries out basic research studies on the economic problems of development in Pakistan and other Asian countries. It also provides training in economic analysis and research methodology for the professional members of its staff and for members of other organizations concerned with development problems.

\section{Executive Board}

Mr. Said Hasan H.Q.A.

(Chairman)

Mr. S.A.F.M.A. Sobhan (Member)

Mr. M.L. Qureshi s.Q.A. (Member-Treasurer)

Mr. A. Rashid Ibrahim (Member)

Professor A.F.A. Hussain (Member)
Mr. G.S. Kehar s.Q.A.

(Member)

Mr. M. Raschid T.PK., S.Q.A.

(Member)

Mr. S.M. Sulaiman

(Member)

Dr. Mahbubul Haq T.PK.

(Member)

Mian Nazir Ahmad T.Q.A.

(Secretary)

Director: PROFESSOR NURUL ISLAM

Senior Research Adviser: DR. BRUCE GLASSBURNER

Research Advisers: DR. RONALD SOLIGO; DR. W. ERIC GUSTAFSON;

DR. WARREN C. ROBINSON; MR. WILLIAM SELTZER;

MR. KEITH B. GRIFFIN

Senior Fellows: $\quad$ DR. S.A. ABBAS; DR. M. BAQAI; DR. MAHBUBUL HAQ; PROFESSOR T. HAQ; PROFESSOR A.F.A. HUSSAIN;

DR. R.H. KHANDKAR; DR. TAUFIQUE KHAN; PRO-

FESSOR M. RASHID; DR. M. AKHLAQUR RAHMAN;

MR. RAHMAN SOBHAN

Foreign Advisory Board

PROFESSOR HOLLIS B. CHENERY, Harvard University

MR. JUST FAALAND, Christien Michelsen Institute, Norway

PROFESSOR LLOYD REYNOLDS, Yale University

PROFESSOR E.A.G. ROBINSON, Cambridge University

PROFESSOR JAN TINBERGEN, Netherlands Economics Institute 
MONOGRAPHS IN THE ECONOMICS OF DEVELOPMENT

No. 14

Social Characteristics of

The People of Karachi

IMTIAZUDDIN HLSAIN

MOHAMMAD AFZAL

SYED AMJAD ALI BAHADUR RIZVI

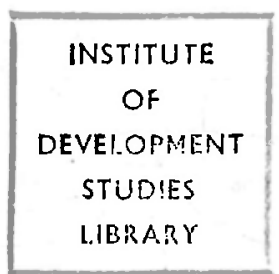

October 1965

PAKISTAN INSTITUTE OF DEVELOPMENT ECONOMICS

Old Sind Assembly Building

Bunder Road, Karachi

(Pakistan) 


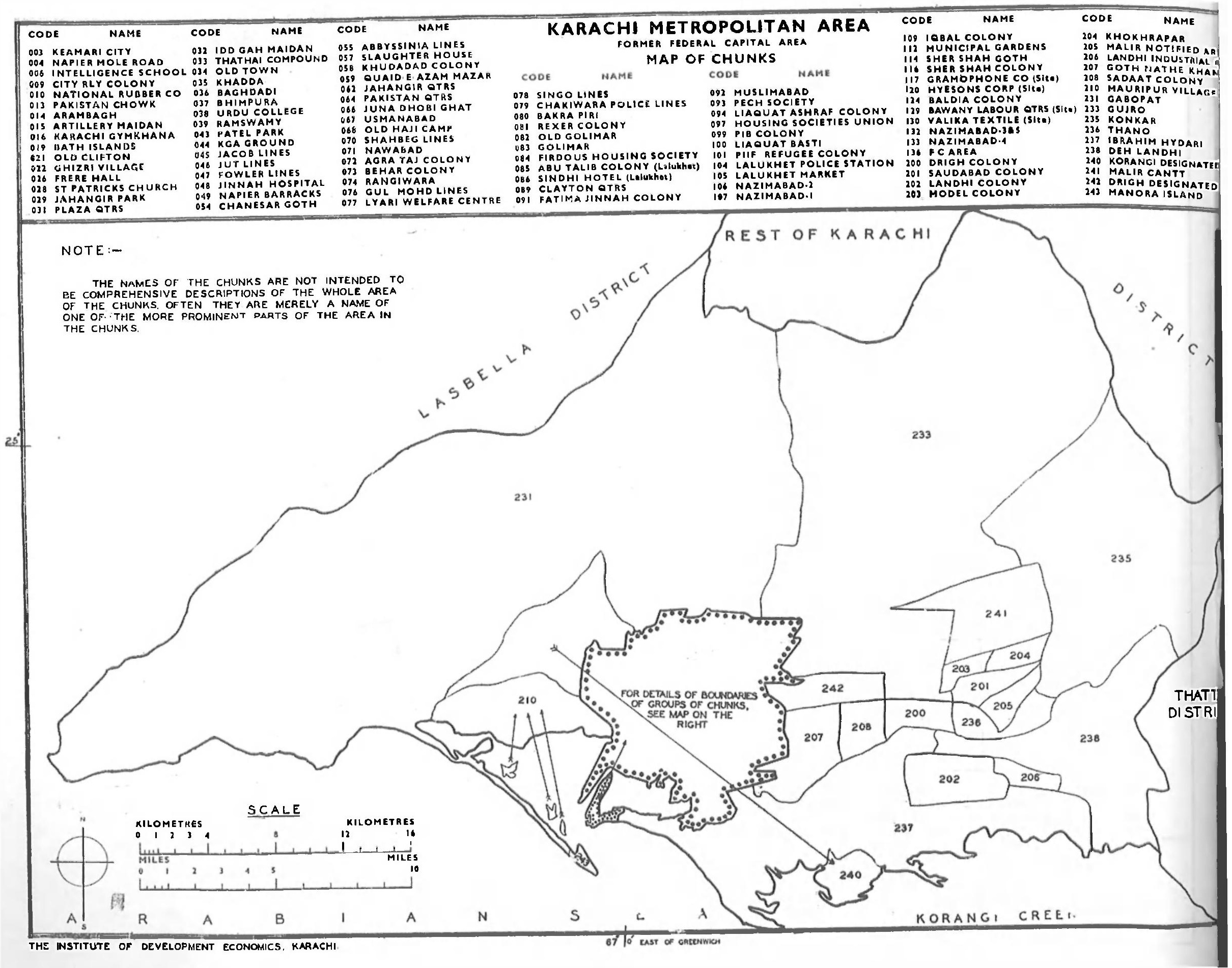




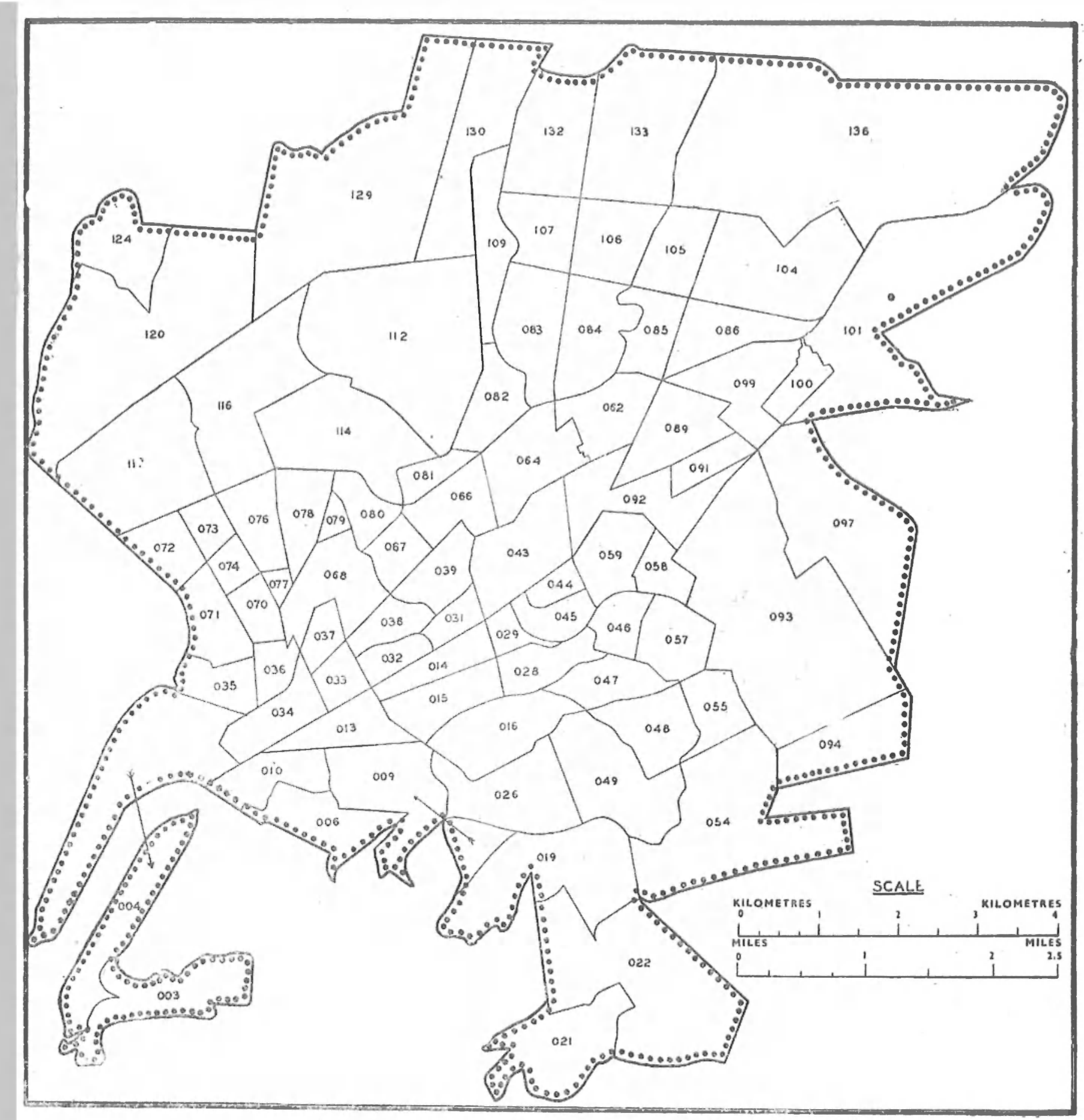


Husain, Imtiaz!ddin et al.

Monographs in the Economics of Development

No. 14: Social Characteristics of the People of Karachi

For other books in the same series

plias? see backcover.

Published by

The Pakistan Institute of Development Economics Karachi

Printed in Pakistan

At the Inor Services Press Ltd., 17, near Napier Barracks P.O. Karachi-4 OCTOBER 1965 


\section{PREFACE}

This monograph on social characteristics of the people of Karachi is the second of three monographs on the people of Karachi by the staff of the Demographic Section. These monographs are based on the results of the sample survey of the population of Karachi, conducted in 1959. The basic data from the survey were presented in this Institute's previous publication, Statistical Papers: No. 2, while an earlier monograph presented an analysis of the data relating to the demographic aspect. The present one is an attempt to analyse the data on social characteristics. A study on economic characteristics will follow shortly.

The authors owe sincere thanks to Dr. Karol J. Krotki, Dr. Warren C. Robinson and Dr. Bruce Glassburner for their useful comments on the earlier drafts. They are particularly indebted to Dr. Sultan S. Hashmi who not only helped them with his useful advice at all stages, but also was kind enough to write the introduction of this monograph.

M. Zaman, Publication Officer of the Institute, was responsible for technical processing to bring the monograph in the present printed shape. The authors appreciate his efforts.

IMTIAZUDDIN HUSAIN

Mohammad AfZaL

S. A. A. B. RIZVI

Karachi,

October 10, 1965 


\section{CONTENTS}

\begin{tabular}{llllll} 
& & & & & \multicolumn{2}{r}{ Page } \\
Map & $\ldots$ & $\ldots$ & $\ldots$ & $\ldots$ & $\ldots$ (ii) \\
Preface & $\ldots$ & $\ldots$ & $\ldots$ & $\ldots$ & $\ldots$ (v) \\
Introduction & $\ldots$ & $\ldots$ & $\ldots$ & $\ldots$
\end{tabular}

Chapter 1

Enrolment Status of School-Age Population of the People of Karachi... $\quad$.. 5

Chapter 2

Migrant Status of the People

$\begin{array}{llll}\text { of Karachi } \quad \ldots & \ldots & 37\end{array}$

Chapter 3

Family Composition of the People of

Karachi

Chapter 4

Housing and Living Conditions of the

People of Karachi $\quad \ldots \quad$... 99

$\begin{array}{lllllll}\text { Glossary } & \ldots & \ldots & \ldots & \ldots & \ldots & 151\end{array}$

(vii) 


\title{
INTRODUCTION
}

\author{
Dr. Sultan S. Hashmi
}

This monograph presents analysis of the social characteristics of the people of Karachi based on the sample survey data obtained in 1959. The survey data consisted of information on demographic, social and economic variables and were published separately in a Statistical Paper [2]. Analysis of the demographic data has already been published [1] and a monograph dealing with the economic characteristics is now under publication.

The sample survey on the average, covered about $3 \frac{3}{4}$ th per cent of the population of Karachi or the former Federal Capital Area comprising an area of 2,102 square kilometers. In other words, the area covered is Greater Karachi and is not the same as Karachi designated in the 1961 Census nor is it in agreement with the present district of Karachi. The area covered is smaller than the district of Karachi and is shown on the map on pages (ii) and (iii). For simplicity of presentation the word Karachi is used throughout in this monograph to denote the area covered in the survey. For more details, see [2, pp. 1-20;1, pp. 1-10]. The survey was essentially a survey of regular households and had excluded population living in institutions and open plans.

Karachi has the largest urban population agglomeration and is also the largest commercial and industrial centre of Pakistan. According to the 1941 Census, Karachi had a population of 436 thousands and the 1951 Census revealed a figure of 1.126 million. From the survey data it is estimated that as of April 1959, Karachi had a population of 1.840 million and as of February 1, 1961 (census date), it had increased to 2.032 million [1, pp. 18-19]. Karachi experienced an unprecedented increase of 158.4 per cent during the decade $1941-51$. The annual geometric rate of growth during this decade was 10.0 per cent, In a period of twenty years (1941-1961) the population of Karachi increased almost five folds. 
Partition of the Indo-Pakistan subcontinent in 1947 is the main factor attributed to the rapid growth of the population of Karachi. According to the survey more than four-fifths of its population were migrants (or first generation progeny of migrants) from various parts of India and Pakistan. A major proportion or about four-fifths of the migrants came from India as a result of the partition of Indo-Pakistan subcontinent. Karachi is still growing rapidly and in-migration (migration from other parts of Pakistan) is an important factor in its growth. What happened to the agrarian and semi-urban population who moved into the highly urbanized, commercial and industrial area of Karachi? In the city life social problems emerge from awareness of better living standard, unfulfilled aspirations for achieving better living standard and from cultural conflicnt. An effective solution of such problems requires a knowledge of the social characteristics of the population. What are the social conditions presently existing in Karachi and how are these conditions interrelated to each other? This monograph, based on the available data, attempts to answer these questions at least partly if not fully.

\section{Purpose}

The object of this monograph is limited in scope because, firstly it was not feasible to exhaust all the data on social characteristics published in the Statistical Paper [2] and secondly it cannot deal thoroughly with each social characteristic which involves complex questions and need supporting data. The survey which has provided data for this study is a one-time multi-subject survey covering general demographic, social and economic characteristics of the people. This monograph is intended to provide a broad picture of the social conditions in Karachi to its reader in general and to the city planners in particular. The analysis present will hopefully permit comparison of the social conditions in Karachi with the social conditions prevailing in other metropolitan areas of Pakistan or of other countries.

The monograph had an additional objective of giving on-the-job training to the members of the Demographic Section in research and analysis of the survey data.

\section{Contents of the monograph}

The monograph besides this introduction and the glossary at the end is divided into four chapters. The detailed contents and list of tables of each chapter are given in a uniform way at the beginning and the references are set forth at the end of each chapter.

Following the introduction the enrolment status of school-age population is dealt with in Chapter 1. Enrolment status of school-age population is studied by social, economic and geographic characteristics. In this chapter it is pointed out that only about one-third of the school-age population was attending school in 1959. In addition, it is shown that there is a high drop-out rate after primary grades. This provides a challenge to the educationists to increase their efforts in providing more educational facilities to the children in Karachi.

In Chapter 2 migrant status of the population is analysed in terms of geographic, demographic, economic and social characteristics. In this chapter, it is shown that two-thirds of the immigrants who came to Karachi from India belonged to Northern Indian area which was adversely affected by the 1947 Partition riots. Most of the in-migrants in Karachi hail from former Panjab and former North-West Frontier Provinces and only a few migrated to Karachi from the former Sind province in which Karachi is situated. Immigrants from India are better off in respect of occupation, income, housing conditions and their share in school-age persons going to school, than in-migrants or natives.

In Chapter 3 analysis is made of the family composition in Karachi in terms of demographic, economic and social factors. The analysis shows that nuclear family is the most prevalent form of family in Karachi. The nuclear families have higher birth rate than the extended or joint families. Unemployment is highest in joint families. The incidence of polygyny in Karachi is insignificant.

In Chapter 4 picture has been presented about the housing conditions in Karachi. The basic conditions of the housing are household size, type and tenure of habitation and facilities in the habitation. The housing conditions have been studied in terms of geographic social and economic factors. The anlyasis shows that in 1959 one-fourth of the population of Karachi was living in substandard houses called juggies. 


\section{REFERENCES}

1. Hashmi, Sultan S., The People of Karachi, Denographic Characteristics. (Karachi: Pakistan Institute of Development Economics, 1965).

2. Hashmi, Sultan S; Masihur Rahman Khan and Karol J. Krotki, The People of Karachi; Date from a Survey. (Karachi: Pakistan Institute of Development Economics, 1964). 
Social Characteristics of The People of Karachi

\author{
CHAPTER 1 \\ Enrolment Status of School-Age \\ Population
}

MOHAMMAD AFZAL 


\section{CONTENTS}

\section{Chapter 1}

ENROLMENT STATUS OF SCHOOL-AGE POPULATION

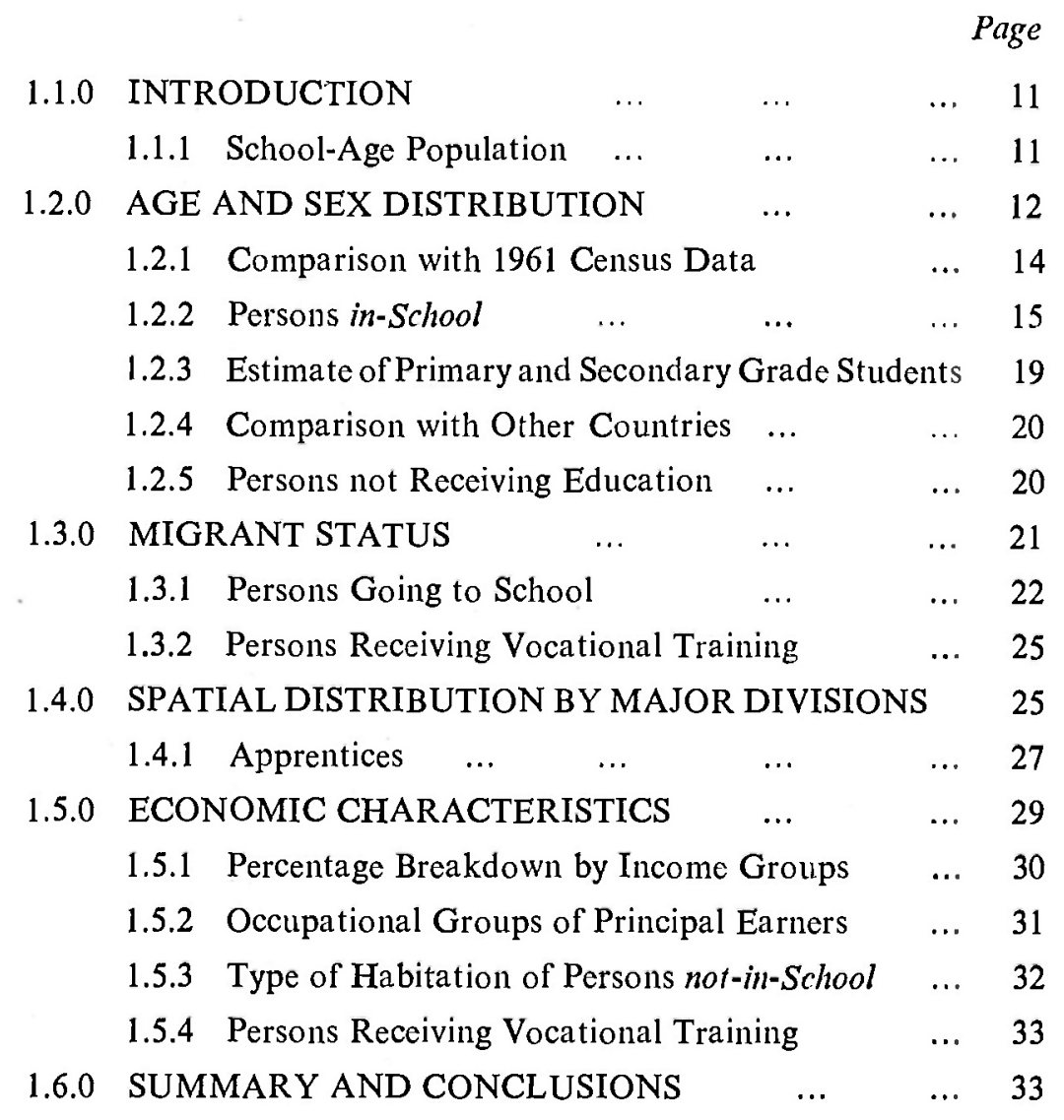




\section{LIST OF TABLES}

Table 1.1 Percentage Distribution of School-Going Persons of Age 5-19 Years in Primary, High and College Grades

... $\quad$..

...

Table 1.2 Percentage of Persons Going to School Out of the Total School-Age Population in Each Age and Sex Group

Table 1.3 Comparative Proportions of Persons in Selected Age Groups, 1961

Table 1.4 School.Going Population of Karachi

Table 1.5 Comparison with Other Countries

Table 1.6 Comparative Percentage Distribution of SchoolAge Persons and Total Population by Migrant Status

Table 1.7 Proportions in-School of the School-Age Persons by Migrant Status and Age ...

Table 1.8 Percentage Breakdown of Total in-School Population in each Age Group by Migrant Status..

Table 1.9 Percentage Distribution of in-School Persons and Not in-School and Ratio of in-School to School-Age Population By Major Divisions ...

Table 1.10 Age and Sex Specific Percentages of in-School Persons by Income $\quad . . \quad$...

Table 1.11 Percentage Breakdown of the $i n-S c h o o l$ Persons by Income Group $\quad \ldots \quad \ldots \quad \ldots$

Table 1.12 Percentage Distribution of in-School Persons By Occupational Groups of Principal Earners... 


\section{CHAPTER 1}

ENROLMENT STATUS OF SCHOOL-AGE POPULATION

\subsubsection{INTRODUCTION}

In order to provide an adequate number of schools, the educational authorities need an adequate understanding of the prevelent enrolment status and the socio-economic conditions of the school-age population. To fulfill this need, an analysis of Karachi's educational data as contained in the last chapter of the statistical publication, The People of Karachi [4, pp. 321-43] has been undertaken in this chapter.

This chapter is an attempt $i$ ) to investigate what proportion of the school-age population in Karachi is actually receiving and what proportion is not receiving education; ii) to explore the related factors such as spatial distribution, migrant status and socio-economic condition of the family, which help or hinder the way of a school-age child to go to school.

1.1.1 School-Age Population: The operational definition of the schoolage group adopted in this chapter is: the persons from the age of five years to twenty years.

All over Pakistan as well as in Karachi, a child is admitted to a primary school when he is at least five years old [5, p. 117]. But normally, a child spends a year in kindergarten [1, p. 441] before he enters the first grade in school. Hence, a child entering a school at the age of five years should ideally finish his primary school (five years of school after kindergarten) at the age of eleven years, his high school (five years after primary school) at the age of sixteen years and take his Bachelor's degree (four years of college after high school) at the age of twenty years.

To find the actual proportion of school-age persons in high school grades and above, recourse was made to the 1961 Census [6, pp. IV-3839] of Pakistan as the statistical paper [4] does not give data on school enrolment by grades. 
TABLE 1.1

PERCENTAGE DISTRIBUTION OF SCHOOL GOING PERSONS OF AGE 5-19 YEARS IN PRIMARY, HIGH, AND COLLEGE GRADES

\begin{tabular}{lcccccc}
\hline Grades & & & \multicolumn{2}{c}{ Selected age groups } & \\
\cline { 3 - 6 } & & & & $5-9$ & $10-14$ & $15-19$ \\
\hline All & $\ldots$ & $\ldots$ & $\ldots$ & 100.0 & 100.0 & 100.0 \\
Primary & $\ldots$ & $\ldots$ & $\ldots$ & 100.0 & 70.8 & 8.3 \\
High & $\ldots$ & $\ldots$ & $\ldots$ & 0.0 & 29.2 & 84.9 \\
College, elc. & $\ldots$ & $\ldots$ & 0.0 & 0.0 & 6.8 \\
\hline & & & & & Source: [6, pp. IV. 38-39]
\end{tabular}

It is clear from Table 1.1 that almost all the persons in age group 5-19 years of the school-going population attend primary and high schools while the percentage of those attending colleges among them is very small. Thus, in selecting age group 5-20 as school age group, our investigations are more concerned with the education upto or about high school level rather than college level.

The question then arises, why we are more concerned with primary and secondary (i.e., high school) education? One reply to this question is that "primary education is the right of every citizen and it is the primary duty of the State to provide facilities for free primary education" [9, p. 27]. Primary education is necessary to develop all aspects of a child's personality and "to awaken in the child a sense of citizenship and civic responsibilities as well as a feeling of love for his country and willingness to contribute to its development" [5, p. 173].

After the primary education, which is of supreme importance for every body in the country, secondary education is "universally recognized to be the critical one ... It is the stage where most of the skilled manpower of a nation will be determined, where character building and qualities of future leadership can best be developed" [5, p. 111]. It is, in any case, clear that higher education (colleges and universities) will for a long time affect on a relatively small part of the total population.

\subsubsection{AGE AND SEX DISTRIBUTION}

The total estimated population of Karachi according to the survey [4] is $18,03,175$ persons, of which $9,99,250$ (55.4 per cent) are males 
and 8,03,925 (44.6. per cent) are females. The survey, however, excluded some 37. thousand persons who were living either in institutional households or had no place to live.

The school-age population (i.e., 5-20 age group) is 89.3 per-cent (or $7,08,000$ persons) of the total population; the percentage of male and female school-age population to total male and total female population respectively is 37.7 (or $3,76,925$ persons) and 41.20 (or $3,31,075$ persons). The age groups 5-9 years, 10-14 years and $15-20$ years are 14.5 per cent, 11.4 per cent and 13.4 per cent respectively of the total population. Or, $36.8,29.1$ and 34.1 per cent of the school-age population.

The survey further reveals that of $2,41,975$ school-going persons, $1,47,450$ are males and 94,525 females.

We observe that the percentage of females out of the total persons in-school is 39.1 ; which is about 10 percentage points less than the corresponding percentages for the developed countries like Sweden, the United Kingdom, and the United States of America [11, pp. 334-337].

TABLE 1.2

\section{PERCENTAGE OF PERSONS GOING TO SCHOOL OUT OF THE TOTAL} SCHOOL-AGE POPULATION IN EACH AGE AND SEX GROUP

\begin{tabular}{lllllll}
\hline Age group & & & & \\
& & & & \\
& & & & \\
\hline $5-20$ & $\ldots$ & $\ldots$ & $\ldots$ & 34.2 & 39.1 & 28.6 \\
$5-9$ & $\ldots$ & $\ldots$ & $\ldots$ & 35.6 & 39.1 & 31.9 \\
$10-14$ & $\ldots$ & $\ldots$ & $\ldots$ & 51.3 & 58.4 & 43.1 \\
$15-20$ & $\ldots$ & $\ldots$ & $\ldots$ & 18.0 & 22.1 & 11.9 \\
\hline
\end{tabular}

Table 1.2 shows that the highest parcentage (51.3) of school-going population comes from the age group 10-14 years. This age group on the other hand has the lowest proportion (29.1) in the school-age population. This high parcentage of school-going population from the age groups 5-9 years and 10-14 years is due to the fact that most of the persons in this age group attend primary schools or just above and 
later on there are big drop-outs. Many of those who attend primary schools have no opportunity for further education [10, p. 11]. This is not only true for Karachi but even on the world scale.

Looking at the percentages of males and females separately we observe that for the age group 5-9 years the differences in percentages between males and females is not as much as it is in the higher age groups, indicating almost equal opportunities for males and females in the earlier primary grades and a more rapid drop out rate for females than for males in the higher grades.

1.2.1 Comparison with 1961 Census Data: Comparing our estimates with school enrolment data from the 1961 Census of population, we have to select 15-19 years as the third age grcup because the census does not provide population figures for the age group 15-20 years, nor does it give the population distribution in single years of age so that the population for the age 20 years could be added to that of the age group 15-19 years to get the tolal population in the age grol'p 15-20 years.

Table 1.3 shows that comparative proporticns of the persons in the selected groups out of the total population of Karachi as given by the survey with those of 1961 Census for Karachi, Lahore, Rawalpindi, and Dacca.

TABLE 1.3

COMPARATIVE PROPORTIONS OF PERSONS IN SELECTED AGE GROUPS, 1961

\begin{tabular}{|c|c|c|c|c|c|c|}
\hline \multirow{2}{*}{$\begin{array}{l}\text { Selected } \\
\text { age } \\
\text { group }\end{array}$} & \multicolumn{6}{|c|}{$\begin{array}{l}\text { Percentage of persons in selected age-group } \\
\text { out of Census } 1961 \text { Population }\end{array}$} \\
\hline & $\begin{array}{l}\text { Surve } \\
\text { pop } \\
\text { of } K\end{array}$ & & $\underset{\text { city }}{\text { Karachi }}$ & $\begin{array}{l}\text { Lahore } \\
\text { city }\end{array}$ & $\begin{array}{c}\text { Rawal- } \\
\text { pindi } \\
\text { city }\end{array}$ & $\begin{array}{c}\text { Dacca } \\
\text { city }\end{array}$ \\
\hline $5-19$ & $\ldots$ & 34.9 & 35.2 & 36.8 & 35.8 & 35.1 \\
\hline 5- 9 & $\ldots$ & 14.5 & 14.5 & 15.3 & 14.4 & 15.1 \\
\hline 10.14 & $\ldots$ & 11.4 & 11.0 & 11.2 & 11.1 & 10.9 \\
\hline $15-19$ & $\ldots$ & 9.0 & 9.7 & 10.3 & 10.3 & 9.1 \\
\hline
\end{tabular}


The table shows that there is not much variation in the proportions of persons in the selected age groups when the survey data are compared with the census data not only of Karachi city but also of the other important cities like Lahore, Rawalpindi and Dacca. This indicates that the proportion of the school-age persons given by the survey is comparable with the census data and is internally consistent.

1.2.2 Persons in-School: Table 1.4 shows the comparison of schoolgoing persons in Karachi according to The People of Karachi: Data from a Survey [4, Table 8.06] and the 1961 Census [6, pp. IV-46-47]. (For sake of comparison, the percentage for the age group 15-19 years is also calculated).

We observe from the table that the population distribution which the survey [4] gives is comparable with that of the 1961 Census population of Karachi [6] for each age and sex group. Also the population in each age and sex group is higher in 1961 Census than that given by the 1959 survey. However, when we compare the percentages of persons attending school in each age group, a striking difference is observed. The highest of these differences is in the age group 5-9 years, where the percentage attending school as given by the survey is more than double the percentage given by the 1961 Census (in fact, the census should give higher figures because it was taken two years later than the survey].

The question then arises, why is there so much difference in the proportions of persons attending school revealed by the census data and the survey data? Is it due to the difference in the definition of school-going persons? Do the areas covered by the two differ so much as to make such a big difference? Or, is it due to underenumeration in the census and overestimation in the survey. We shall discuss these questions one by one.

As regards the first question we do not feel that the difference in the phraseology of the questions asked in the survey and the census would make much difference. In the survey occupation was asked of all the persons irrespective of age. Those reported as students were classified as school-going persons. This may very well include persons receiving education in maktabs (mosques or religious institutions). Some persons who had finished schooling and were lcoking for jobs 


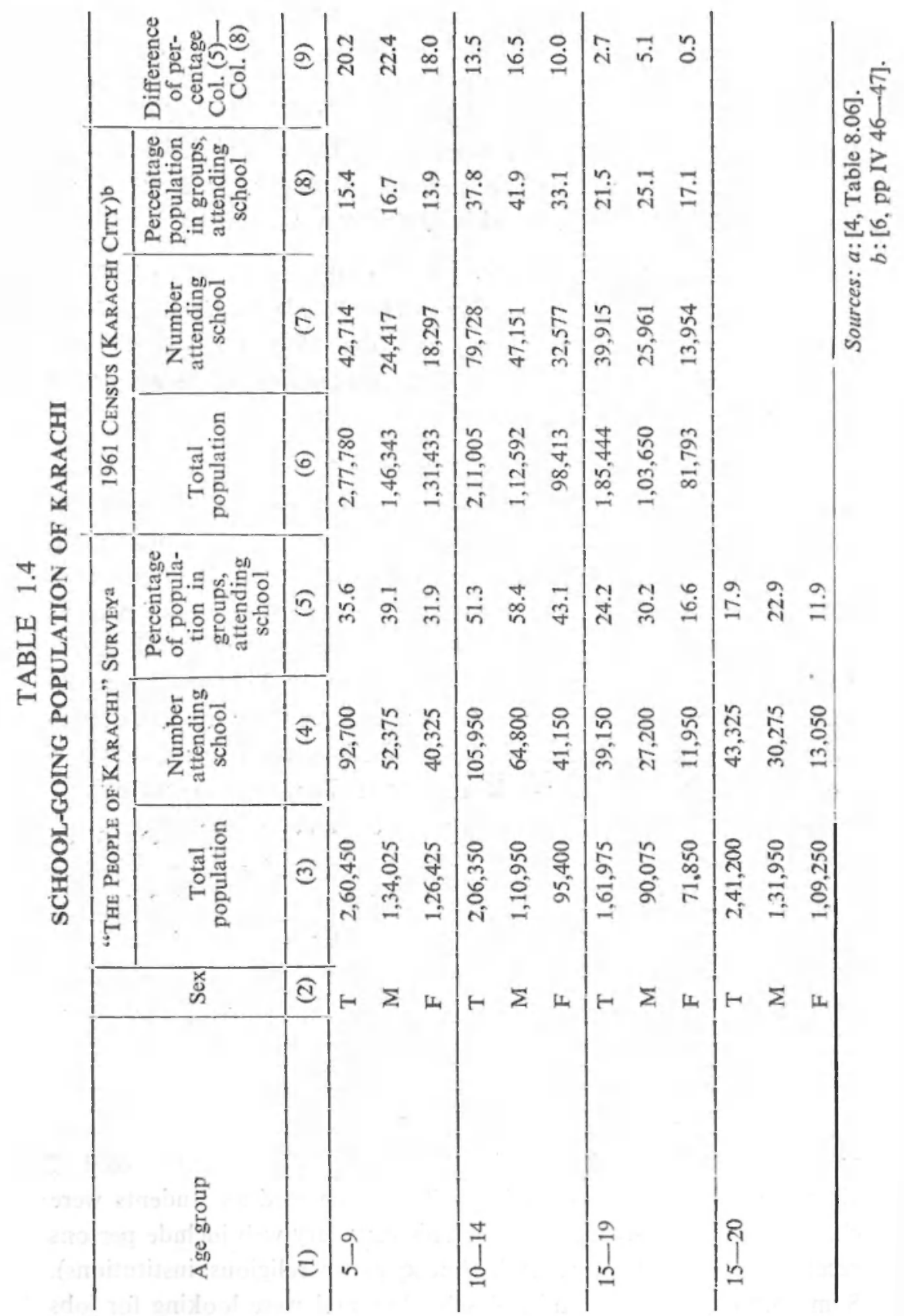


might also have reported themselves as students [4, p. 321]. Therefore, the school-going persons given by the survey include persons receiving education in all types of educational institutions (except those who were working as apprentices) whether recognised or not recognised and also maktabs.

In the census, the question about school attendence was asked in this way: "Are you attending a school or college or an institute of education?" [8, p. IV]. It seems obvious that the school-going persons according to the census, also include those attending maktabs and other private institutions. Thus, the difference in the two definitions is not likely to make a major difference.

According to the census, Karachi city includes all areas of Karachi District except the rural talukas. On the other hand, "the a rea covered in the survey is the present Karachi District minus the 37 villages" $[4$, p. 2]. Hence, we find a difference in the areas covered by the census and the survey. But this difference is only of a rural area which in fact if included into the city reduces the percentage of school-going persons. For example, the persons attending school in the age group 5-9 years is 14.7 for the Karachi District (which includes all the 94 villages of rural talukas). This is smaller than the percentage for the Karachi city which is 15.4 per cent. Similarly, for the age group 10-14 years the percentage is 36.8 as compared with 37.8 for Karachi city. Hence, we find that the inclusion of rural areas actually reduces the percentage of the school-going persons. Therefore, the inclusion of a part of the rural talukas in the survey makes little difference as far as percentages of school-going persons are concerned.

There is, however, a very real possibility of over-reporting of students in the survey because of the form of the questionnaire employed. The enumerators were asking a question on occupation of the members of the households interviewed. Normally, occupation would imply some labour force connection, whether the work be for pay or not. Also normally, one might not think of a child as having an occupation. Thus, the tendency for most respondents would initially be to return all young children as having no occupation. Such an answer would probably be resisted by the enumerator who might prompt the respondent with a 
question such as "but, he is a student is he not?" to which the respondent might very well reply in the affirmative whether or not the child was actually enrolled in an institution. Or, even without arguing the point with the respondent the enumerator might well have decided that the respondent was wrong and then have entered the occupation of the children involved as "student" on his own judgement.

This interpretation is borne out by the fact that the discrepancies between the census and survey school populations are greatest at the lowest age group ( 5 to 9 , where the difference is nearly 50,000 or 100 per cent of the census figure), moderates with age increases (10 to 14 shows a difference of about 25,000 or one-third of the census figure) and disappears by the upper teens (age group 15 to 19 shows the census total slightly higher than the survey total as one would expect because of the difference in the dates of the two enumerations). In other words, the "occupation" question asked in the survey was probably badly applied to the lower age groups for which the concept of "occupation" is rather vague, was less troublesome in the age groups in which labour force participation does begin to occur and then vanished as the occupational status of young adolescents (student or otherwise) became a quite clear-out thing.

The Directorate of Education, Karachi [2, pp. 18-19] gives actual enrolment in primary and secondary schools for the year 1960-61 as $1,75,403$, while the 1961 Census gives as $1,59,621$ persons attending primary and high school grades (of course for the same year). Considering the fact that the enrolment figure relates only to students in the schools recognized by the Education Department and does not include students from a vast number of unrecognised schools and maktabs whereas the census figure does include them, one would expect this figure to be lower than either the survey or census figures on school population.

To explain this apparent anomaly it is sometime argued that the enrolement figures are exaggerated to a certain extent, because the school authorities want to show more and more number of students on their rolls so as to get more grant from the government. However, there is sufficient reason to believe that such a motive would not arise in a 
city like Karachi, where the existing number of recognised schools are inadequate to fulfill the existing demands. In fact, many schools have to run more than one shift.

Another objection to the enrolment figures is that they pertain to enrolment of the students at the beginning of the year whereas many of them drop out during the course of the year. These figures, therefore, do not account for the drop-out of students which occurs during the year, particularly in the primary grades. Hence, it is difficult to compare the enrolment figures with those of the census which was held in the month of January or the survey held in April (i.c., in the last quarter of the academic year when most of the drop-out had already taken place).

1.2.3 Estimate of Primary and Secondary Grades Students: As discussed earlier, the estimate of the number of person in-school in 1959, according to the survey, is much higher than the number given for the year 1961 by the census. An estimate of primary and secondary grades students separately will be helpful to those interested in knowing how many school-going persons are receiving education outside properly recognised and standardised schools. Assuming that the proportion of those persons who were attending primary and secondary (high) school out of the total persons enrolled were the same in 1959 as given by the 1961 Census, we estimate that all the 92,700 persons in the age group 5-9 years, 75,055 persons in the age group $10-14$ years and 350 of persons in the age groups $15-20$ years are in primary grades. Thus, the total estimated number of persons in the primary grades is $1,71,264$.

Similarly, we estimate that there are 66,815 persons of age $10-20$ years in the high sch ool grades in Karachi. The rest of the 3,896 persons out of the total of 2,41,975 parsons going to school, are aitending colleges, etc.

The estimates of the number of male and fomale persons attending primary and high school grades are made similarly by applying the parcentages of school-going population, attending primary and high school grades in Karachi according to 1961 District Census Report [6]. 
Thus, the number of male attending primary and high school grades come out to be 1,00,600 and 43,826 respectively. The number of female attending primary and high school grades are 70,664 and 22,987 respectively. The rest of the 3,022 male and 874 female out of the male and female persons going to school, in the school age, are attending college, etc.

1.2.4 Comparison with Other Countries: Table 1.5 gives the per cent of population aged 15-19 years, enrolled in primary and secondary levels of education for Karachi (survey estimate and Directorate of Education enrolment figures), Pakistan, India, Ceylon, Sweden, the United Kingdom and the United States of America.

TABLE 1.5 COMPARISON WITH OTHER COUNTRIES

\begin{tabular}{|c|c|c|c|}
\hline Place & & Year & Percentage \\
\hline \multicolumn{4}{|l|}{ 1) Karachi } \\
\hline i) Survey & $\ldots$ & (1959) & 37.8 \\
\hline ii) School enrolment & $n .$. & $(1960)$ & 26.0 \\
\hline 2) Pakistan & $\ldots$ & $(1960)$ & 20.0 \\
\hline 3) India & $\ldots$ & $(1959)$ & 29.0 \\
\hline 4) Ceylon & $\cdots$ & $(1959)$ & 60.0 \\
\hline 5) Sweden & $\ldots$ & $(1959)$ & 71.0 \\
\hline 6) United Kingdom & $\cdots$ & $(1959)$ & 81.0 \\
\hline 7) United States of America & $\ldots$ & $(1960)$ & 81.0 \\
\hline
\end{tabular}

We observe that so far as education is concerned, Pakistan and India lag far behind not only the other developed countries of the world but also their close neighbour, Ceylon.

Even in the case of the survey figures for Karachi which take into account all students whether in recognised or unrecognised schools the percentage is much smaller than the percentage enrolment for the other countries.

This indicates how much effort is needed in the field of education to bring Pakistan in level with other advanced countries of the world.

1.2.5 Persons Not Receiving Education: Out of the total of 7,08,000 persons in the school age, there are $4,66,025$ persons ( 65.8 per cent), $-2,29,475$ (60.8 per cent) males and 2,36,550 (71.4 per cent) femaleswho are not receiving education. 
Vocational trainees (apprentices): We have seen [4, Table 8.06] that only 1.30 par cent of the persons not receiving education are apprentices (or receiving vocational training). Their percentage out of the total school-age population is 0.85 . It seems reasonable, therefore, that the discussion regarding persons who are working as apprentices should be taken beyond the school-age limit to cover all ages. However, it will not be out of place to mention that 84 per cent of persons who are apprentices are in the school age and the rest of them are of beyond this age.

Working: The percentage of those in the school-age who are not receiving education and are working is 21.2 . Almost all of them are of the age 10-20 years.

Not working: The percentage of population, not receiving education and also not working is 77.5. The number of females is almost double that of males.

It is interesting to note that 46.30 per cent of the persons who are neither receiving education nor working, are of the age 5-9 years. There are more females than males in this age group, but the difference is not much.

The age group 10-14 years forms 24.5 per cent of the persons not receiving education. The reasons for this group being smaller are that i) the proportion of the population in this age group is smaller, and $i i)$ this group is the biggest contributor of the school-going population. The proportion of the females, not recsiving education, in this group is almost $1 \frac{1}{2}$ times the proportion of males.

The next higher age group 15-20 years contributes 29.2 per cent of the persons not receiving education. We note here that the percentage of this age group is relatively higher than that of the previous one. The reason for this is that the proportion of the female is almost 9 times the proportion of the male in this group. We observe here that the number of males not receiving education goes on decreasing when we go along from the lower age group to the high. On the other hand, the number of females increases.

\subsubsection{MIGRANT STATUS}

Out of 7,08,000 persons of school age in Karachi 1,19,975 (16.94 per cent) are native and 5,84,050 (82.49 per cent) migrants; $1,09,800$ (15.51 
per cent) in-migrants and 4,74,250 (66.9 per cent) immigrants. There is no information about 3,975 (5.61 per cent) persons.

TABLE 1.6

COMPARATIVE PERCENTAGE DISTRIBUTION OF SCHOOL-AGE PERSONS AND TOTAL POPULATION BY MIGRANT STATUS

\begin{tabular}{|c|c|c|c|c|}
\hline \multirow{2}{*}{ Migrant status } & & & \multicolumn{2}{|c|}{ Percentage distribution } \\
\hline & & & School-age persons & Total population \\
\hline All & $\ldots$ & $\ldots$ & 100 & 100 \\
\hline Natives & $\ldots$ & $\ldots$ & 16.9 & 16.6 \\
\hline Migrants $\quad .$. & $\ldots$ & $\ldots$ & 82.5 & 82.6 \\
\hline In-migrants & $\ldots$ & $\ldots$ & 15.5 & 17.5 \\
\hline Immigrants & $\ldots$ & $\ldots$ & 66.9 & 65.1 \\
\hline No information & $\ldots$ & $\ldots$ & 5.6 & 2.8 \\
\hline
\end{tabular}

Source: $[4$, Tables 8.01 and 1.20$]$.

It is observed from Table 1.6 that the percentage distributions of school-age persons and total population by migrant status are comparable, except that the immigrants when they are compared with inmigrants, have a higher proportions of school-age persons than in the total population. Also, when the native, in-migrant and immigrant populations are taken separately, the respective proportions of school-age persons in them are 39.2, 40.4 and 34.7. In other words, there is a higher proportion of school-age persons in immigrants than in inmigrants this may be due to the fact that many of the in-migrants come to Karachi because of more job opportunities in this big metropolis of Pakistan and they do not bring their families along with them. On the other hand, the immigrants come once for all to settle here and have their children along with them.

1.3.1 Persons Going to School: Out of all the persons in the school age 34.17 per cent are going and the rest are not gcing to school. The percentage of in-school out of the natives and the migrants, in-migrants and immigrants in the school age are 21.9 and 36.9, 22.29 and 40.28 respectively.

We observe here that the percentages for the natives and the inmigrants are not much different, but in the case of the immigrants it is almost double than that of either the natives or the in-migrants. This 


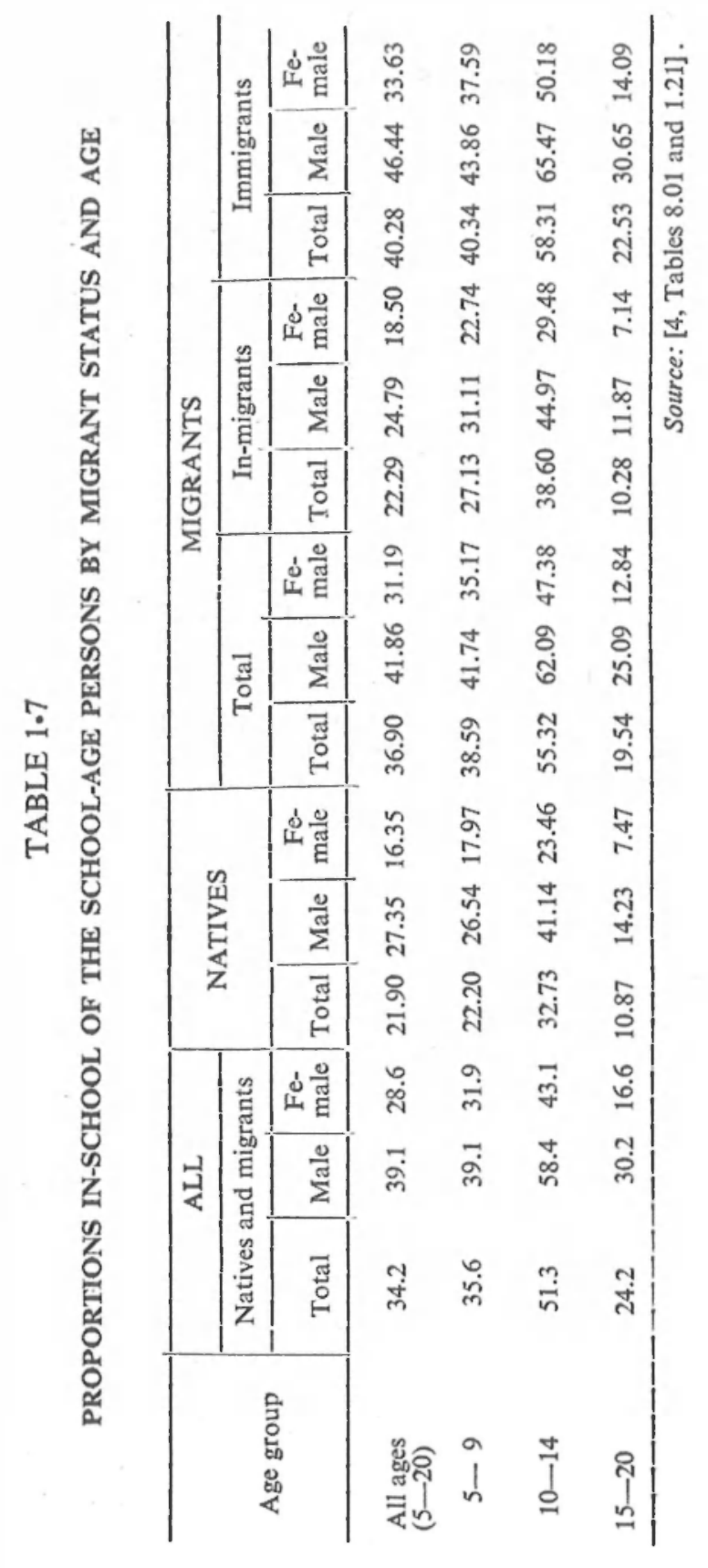


indicates that the immigrants have a higher tendency of sending their children to school than the in-migrants or the natives.

Selected age groups: It is noted from Table 1.7 that the immigrants have the highest overall percentage ( 40.28 per cent) of their school-age persons and also in each individual age group, i.e., 40.84 per cent in 5-9 years, 58.31 per cent in 10-14 years and 22.53 per cent in the age 15-20 years, as in-school. We also observe that irrespective of the migrant status, the proportion of the persons in the age group, 15-20 years inschool, is much smaller as compared to the percentages of the other two age groups. This is another indication that a sharp drop-out of student enrolment occurs when going up from primary to secondary grades.

Comparing males with females, we find that the percentage of inschool males is always higher than the percentage of in-school females.

TABTE 1.8

\begin{tabular}{|c|c|c|c|c|c|c|c|}
\hline \multirow{3}{*}{\multicolumn{2}{|c|}{$\begin{array}{l}\text { Selected } \\
\text { age } \\
\text { groups }\end{array}$}} & \multirow{3}{*}{ Total } & \multicolumn{4}{|c|}{ Migrant status } & \multirow{3}{*}{$\begin{array}{c}\text { No } \\
\text { infor- } \\
\text { mation }\end{array}$} \\
\hline & & & \multirow[b]{2}{*}{ Natives } & \multicolumn{3}{|c|}{ Migrants } & \\
\hline & & & & Total & $\begin{array}{c}\text { In- } \\
\text { migrants }\end{array}$ & $\begin{array}{l}\text { Immi- } \\
\text { grants }\end{array}$ & \\
\hline $\begin{array}{l}\text { All ages } \\
5-20\end{array}$ & $\cdots$ & 100.00 & 10.86 & 89.00 & 10.11 & 78.75 & .04 \\
\hline 5- 9 & $\ldots$ & 100.00 & 11.43 & 88.48 & 10.22 & 78.26 & .08 \\
\hline $10-14$ & $\ldots$ & 100.00 & 11.06 & 88.06 & 9.39 & 79.47 & .07 \\
\hline $15-20$ & $\ldots$ & 100.00 & 9.12 & 90.82 & 11.66 & 79.17 & .06 \\
\hline
\end{tabular}

Source: $[4$, Table 8,01$]$.

From the above table, we observe that in all the age groups, the percentage of the immigrants is much higher as compared to the percentages of the natives and the in-migrants. The percentage of the natives, however, is higher than percentage of the in-migrants except in the age group 15-20 years where the case is reverse. The proportion of immigrants is higher because the immigrants form the major part of the school-age persons as well as the total population. Similarly, the 
high proportion of natives as compared to in-migrants of the in-school persons also seems to be the result of a comparatively higher proportion of natives in the school-age population. The low proportion of natives as compared to in-migrants in the age group 15-20 years is not indicative of lesser tendency of the natives to send their children to high school (secondary grades); in fact, we have seen in Table 1.7 that the in-school proportion of the school-age persons of natives is higher than for in-migrants in this age group.

1.3.2 Persons Receiving Vocational Training (Apprentices): Out of the total of 6,525 persons in Karachi who are receiving vocational training, 6,075 or 93 per cent are migrants: 5,550 persons or 85 per cent immigrants from India, 525 or 9 per cent are in-migrants and 450 or 7 per cent are natives. Thus, the proportions of immigrants, inmigrants and natives in the persons receiving vocational training are not much different to their proportions in the school-age persons and the total population.

\subsubsection{SPATIAL DISTRIBUTION BY MAJOR DIVISIONS}

As described in [4, Appendix F] the whole area of Karachi is divided into 8 major divisions for the survey purpose. It may be mentioned here that the "survey was not specifically designed to study the spatial distribution of the demographic, economic and social traits of the people of Karachi" [4, p. 9].

Table 1.9 shows the percentage distribution of the in-school persons and those not in school according to the major divisions, as well as the percentage in-school out of the school-age persons in each division.

TABLE 1.9

PERCENTAGE DISTRIBUTION OF IN-SCHOOL FERSONS AND NOT-IN-SCHOOL AND RATIO OF IN-SCHOOL TO SCHOOL-AGE POPULATION BY MAJOR DIVISION

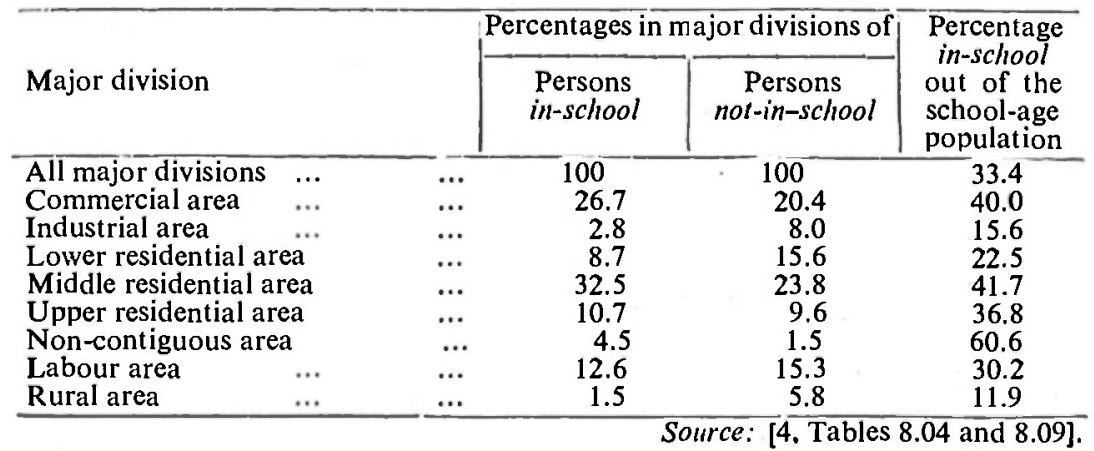


Middle-residentialand commercial areas: From the above table we observe that 59.2 per cent of the in-school persons and 44.2 per cent of the persons not in-school are from the mid-residential and commercial areas. These two areas have, therefore, the highest proporticn in the school-going persons. This may be so because they have the highest proportion of total population as well; also over 40 per cent of their school-age population goes to school.

We observe that these two areas have the highest percentage of persons in each income group [4, Table 4.40]. It is, therefore, difficult to associate the high percentage of persons in-school and out of school in these two areas with the income distribution. Nevertheless, compared to other areas they have the highest percentage of their population with family income more than rupees five hundred per month.

Labour and lower residential areas: The percentage of in-school and not-in-school persons from labour and lower residential areas are 21.3 and 30.9 respectively. We notice here that a very high percentage of school-age persons (second only to rural and industrial areas) is not going to school. Also these two areas have a very high percentage of persons with a family income less than rupees 500 per month. This indicates that the high percentage of persons not going to school in these areas may be due to the fact that there is a higher percentage of persons in the lower income group as compared to others (except the rural areas).

Non-contiguous area: The percentage of in-school and not-inschool persons from the non-contiguous area are 4.5 and 1.5 respectively. We also observe that the non-contiguous area has over 60 par cənt of its population in school age, actually going to school. This may be due to the fact that over 11 per cent of its population has their family income more than rupees 500 per month (highest among all the areas).

Upper residential area: This area which has over 10 per cent of its population with a family income more than five hundred rupees per month (second highest) does not have a high percentage of in-school persons out of its own school-age population. This means that the 
high pərcentage of high income people in this area has not much effect on its proportion of school age persons in-school. But, as we shall see in the Section 1.5 (Economic Characteristics) the higher income families have a higher parcentage of their school-age population in-school, why then this area does not have a high percentage of its school age population in-school? The reason may be that the upper residential area does not consist only of the high class localities such as Old Clifton, the Housing Societies and Bath Island, it also includes such localities of lower middle and lower income level as Napier Barracks, or Slaughter House areas. Moreover, even in the high class localities mentioned above the inhabitants are not exclusively high income people, In fact, these areas have a large number of lower income people living in them.

Hence, a very large numbsr of lower income people in this area cancels out the effect of a relatively larger proportion of high income people, to influence the proportion of school going persons in it.

Industrial and rural areas:These two areas have the lowest propurtion in the school-going persons. Over 85 per cent of their schoolage population is not in-school. This is so because most of the people in these areas are from such low income occupational groups as farmers, fishermen and-all types of labourers.

1.4.1 Apprentices:The highest percentage of apprentices is from the middle residential area [4, Table 8.22]. This area contributes about 39 per cent of the total apprentices. This is because of the highest proportion of the school-age population in this area.

The areas which contribute the next highest percentages of apprentices are the "labour area" (26.8 per cent), and "commercial area" (15.9 per cent).

The other areas which contribute appreciable percentage of apprentices are "lower residential area", "upper residential area" with their percentages as 8.9 and 6.6 respectively.

"Non-contiguous area", "Industrial area", and "rural area" contribute very small proportions i.e., 1.8 per cent, 0.8 per cent and 0.4 per cent respectively. 


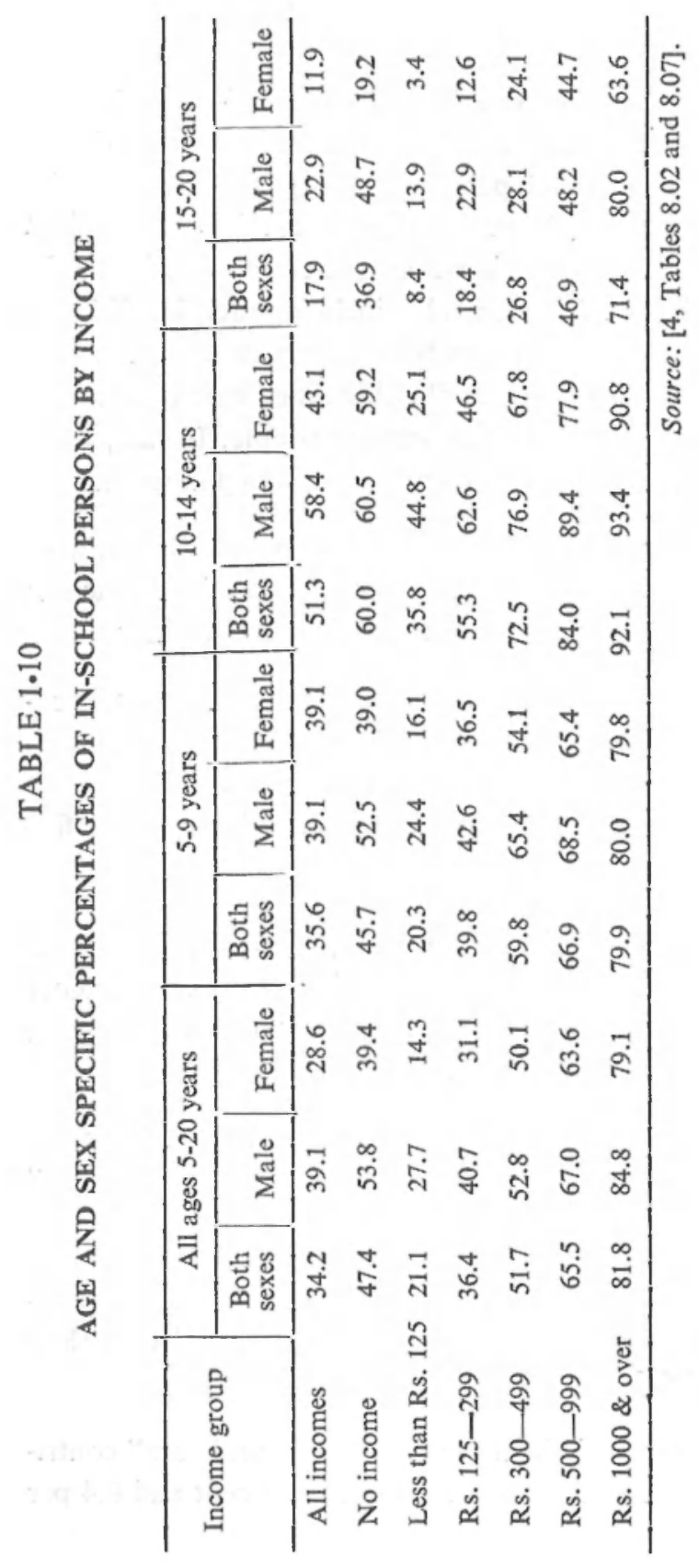




\subsubsection{ECONOMIC CHARACTERISTICS}

"Of all the driving forces of change in the present day, among the strongest are those that show up in economic form, those that bear upon the amount of money and of other resources that is made available for the educational system .... But the particular form that the education takes, the number of pupils who receive it, the number and nature of schools they attend ...-all these things are influenced by economic conditions" [3, p. 22].

The survey data also show that the age and sex specific percentages of in-school persons are positively related with the income groups, i.e., the higher the family income the higher its in-school percentage tends to be and vice versa (see, Table 1,10).

The high percentage in the no-income group is perhaps due to misreporting of the income, probably many of these might be landlords and belong to higher income groups.

It is worth noting that even families in income group Rs. 300-499 are unable to send about half of their children to school. Also in each income group the percentage of in-school persons is higher in the age groups 5-9 years and 10-14 years as compared to the age group 15-20 years, i.e., they have higher percentages in primary school grades as compared to the secondary school grades.

Another interesting point to note in the Table 1.10 is that in the lower income groups the difference in the percentages of males and females attending school is much greater than in the higher income groups. Which means that the daughters of the rich enjoy almost an equal opportunity to go to school as do the sons. The poor, on the other hand, still give more importance to the education of their sons than their daughters. This may ba so because the sons of the poor are considered to be an economic asset for the family as they contribute to the family income when the grow up. On the other hand, the girls are thought to be an economic burden by the poor families because after marriage they no longer live with their parents and so the parents do not get a reward of their investment on the girl's education. This descriminatory tendency, however, is weakening day by day as there is more and more demand for the emancipation of women. 
1.5.1 Percentage Breakdown by Income Groups: We observe that the highest percentage of in-school persons comes from the families with their income in the range of Rs. 125-299 per month (see, Table 1.11)

TABLE 1.11

PERCENTAGE BREAKDOWN OF THE IN-SCHOOL PERSONS BY INCOME GROUP

\begin{tabular}{|c|c|c|c|c|c|c|c|c|c|}
\hline $\begin{array}{l}\text { Selected } \\
\text { age } \\
\text { group }\end{array}$ & Sex & $\begin{array}{c}\text { All } \\
\text { in- } \\
\text { comes }\end{array}$ & $\begin{array}{c}\text { No } \\
\text { in- } \\
\text { come }\end{array}$ & $\begin{array}{l}\text { Less } \\
\text { than } \\
\text { Rs. } 125\end{array}$ & $\begin{array}{c}\text { Rs. } \\
125-299\end{array}$ & $\begin{array}{c}\text { Rs. } \\
300-499\end{array}$ & $\begin{array}{c}\text { Rs. } \\
500-999\end{array}$ & $\begin{array}{l}\text { Rs. } \\
1000 \& \\
\text { over }\end{array}$ & $\begin{array}{l}\text { No } \\
\text { infor- } \\
\text { mation }\end{array}$ \\
\hline $\begin{array}{l}\text { All ages } \\
(5-20)\end{array}$ & $\begin{array}{l}T \\
M \\
F\end{array}$ & $\begin{array}{l}100 \\
100 \\
100\end{array}$ & $\begin{array}{l}1.03 \\
1.07 \\
0.98\end{array}$ & $\begin{array}{l}25.69 \\
28.19 \\
21.68\end{array}$ & $\begin{array}{l}41.04 \\
41.18 \\
40.83\end{array}$ & $\begin{array}{l}16.43 \\
15.44 \\
17.95\end{array}$ & $\begin{array}{r}8.83 \\
8.04 \\
10.08\end{array}$ & $\begin{array}{l}5.19 \\
4.34 \\
6.50\end{array}$ & $\begin{array}{l}1.82 \\
1.74 \\
1.98\end{array}$ \\
\hline $5 \cdot 9$ & $\begin{array}{l}\mathrm{T} \\
\mathbf{M} \\
\mathbf{F}\end{array}$ & $\begin{array}{l}100 \\
100 \\
100\end{array}$ & $\begin{array}{l}1.00 \\
1.00 \\
0.99\end{array}$ & $\begin{array}{l}24.95 \\
27.06 \\
22.19\end{array}$ & $\begin{array}{l}41.40 \\
41.33 \\
41.48\end{array}$ & $\begin{array}{l}18.04 \\
17.61 \\
18.60\end{array}$ & $\begin{array}{l}8.06 \\
6.97 \\
9.48\end{array}$ & $\begin{array}{l}4.93 \\
4.39 \\
5.64\end{array}$ & $\begin{array}{l}1.62 \\
1.64 \\
2.42\end{array}$ \\
\hline $10-15$ & $\begin{array}{l}\mathrm{T} \\
\mathbf{M} \\
\mathbf{F}\end{array}$ & $\begin{array}{l}100 \\
100 \\
100\end{array}$ & $\begin{array}{l}0.92 \\
0.89 \\
0.97\end{array}$ & $\begin{array}{l}29.38 \\
32.72 \\
24.12\end{array}$ & $\begin{array}{l}40.23 \\
40.35 \\
40.03\end{array}$ & $\begin{array}{l}14.84 \\
13.12 \\
17.56\end{array}$ & $\begin{array}{l}8.19 \\
7.52 \\
9.23\end{array}$ & $\begin{array}{l}4.70 \\
3.86 \\
6.01\end{array}$ & $\begin{array}{l}1.74 \\
4.54 \\
2.18\end{array}$ \\
\hline $15-20$ & $\begin{array}{l}\mathbf{T} \\
\mathbf{M} \\
\mathbf{F}\end{array}$ & $\begin{array}{l}100 \\
100 \\
100\end{array}$ & $\begin{array}{l}1.38 \\
1.57 \\
0.96\end{array}$ & $\begin{array}{ll}18.06 \\
20.48 \\
6 & 12.45\end{array}$ & $\begin{array}{l}42.30 \\
42.69 \\
41.37\end{array}$ & $\begin{array}{l}16.85 \\
16.68 \\
17.24\end{array}$ & $\begin{array}{l}12.06 \\
10.98 \\
14.56\end{array}$ & $\begin{array}{r}6.92 \\
5.28 \\
10.73\end{array}$ & $\begin{array}{l}2.43 \\
2.32 \\
2.69\end{array}$ \\
\hline
\end{tabular}

From the above table, we observe that in each age group, the percentage of persons attending school coming from different income groups gozs on decreasing with the increase in income range beyond rupees 300 per month. However, we have already observed from Table 1.10 that the percentage of persons attending school from each income group goes on increasing with the increasing income.

Looking again at the Table 1.10, we find that the percentage of in-school persons out of the males is higher than the in-school percentage out of the females. This is true for the school-age population as a whole and for each individual age group. However, if we look at Table 1.11 given above, which gives the percentage distribution of the male and female in-school population, according to the income groups, we find that the percentage for the male is higher than the percentage for the female for the income groups less than Rs. 300 per month. 
But for the income groups higher than Rs. 300 the proportion of the females in the total females in-school population is higher than the proportion of males in the total male in-school population.

This observation is consistent with the one made earlier from Table 1.10 that, as the income increases the percentages of in-school males and females become closer and closer. Thus, it seems that the higher percentage of school-age females of higher income families increases the overall proportion of in-school females as compared to males in the total male in-school population.

1.5.2 Occupational Groups of Principal Earners:The highest percentage (28.86) of the school-going persons have the occupation of their principal earners under the group "servant and related". The next big contributors (19.6 per cent) are "administrators and managers". The group third in the rank is of "drivers, postmen and related". Their share is 13.2 per cent of the school-gcing population. "clerical workers" contribute 9.9 per cent of the school-going population and their rank order is fourth.

TABLE $1 \cdot 12$

PERCENTAGE DISTRIBUTION OF IN-SCHOOL PERSONIS BY OCCUPATIONAL GROUPS OF PRINCIPAL EARNERS

\begin{tabular}{llllr}
\hline Occupational groups & & & & \multicolumn{2}{c}{ Percentage } \\
\hline All groups & $\ldots$ & $\ldots$ & $\ldots$ & 100 \\
Professional and technicians $\ldots$ & $\ldots$ & $\ldots$ & 4.8 \\
Administrators and managers... & $\ldots$ & $\ldots$ & 19.6 \\
Clerical workers $\ldots$ & $\ldots$ & $\ldots$ & $\ldots$ & 9.9 \\
Sales workers $\ldots \ldots$ & $\ldots$ & $\ldots$ & $\ldots$ & 1.4 \\
Farmers and fishermen & $\ldots$ & $\ldots$ & $\ldots$ & 4.2 \\
Drivers, postmen and related $\ldots$ & $\ldots$ & $\ldots$ & 13.2 \\
Skilled labourers ... & $\ldots$ & $\ldots$ & $\ldots$ & 5.6 \\
Semi-skilled and unskilled labourers & $\ldots$ & $\ldots$ & 5.8 \\
Servants and related & $\ldots$ & $\ldots$ & $\ldots$ & 28.8 \\
Workers not classifiable & $\ldots$ & $\ldots$ & $\ldots$ & 4.6 \\
Unemployed $\ldots$ & $\ldots$ & $\ldots$ & $\ldots$ & 2.0 \\
Persons not in labour forre & $\ldots$ & $\ldots$ & $\ldots$ & 0.1 \\
\hline
\end{tabular}

Source: [4, Table 8.03]. 
"Professionals and technicians", "farmers and fishermen", "skilled labourers", "semi-skilled and unskilled labourers" and "workers not classifiable" each of them contributes a percentage of school-going population within the range of 4 to 6 per cent.

The minimum contribution of 2 per cent or less each are from the groups "sales workers", "unemployed" and "persons not in labour force".

Now if we look in the chapter on income [4, Table 4.02], we observe that more than 80 per cent of the persons in the occupational groups "sales workers", "farmers and fishermen", "semi-skilled labourers" and "unskilled labourers" and "servants and related" have their income less than rupees 125 per month.

Alsc, "clerical workers", "drivers and postmen", and "skilled labourers" have more than 90 per cent of them getting a monthly income of less than rupees 300 per month.

Apart from the fact that high percentages of "professionals and technicians", "administrators and managers", "clerical workers", and "workers not classifiable" are in the income groups of less than rupees 300 per month, these are the groups whose appreciable percentages are in the income groups Rs. 300-499 and rupees 500-and-above per month, rather, these are the groups which possess the majority of persons in the income groups Rs. 300-499 and Rs. 500-and-above.

1.5.3 Type of Habitation of Persons Not-in-School: About 33.6 per cent of the persons not in-school live in "pucca houses", 22.5 per cent live in "semi-pucca" houses and 43.9 per cent in "juggies and others" [4, Table 8.08].

Looking into the chapter on housing and living conditions [4, Table 7.11], we observe that over 90 per cent of the persons living in "juggies and others" earn less than rupees 300 per month. This means that almost all of the 43.09 per cent not receiving education and living in juggies are from the families with monthly income less than rupees 400 per month. 
Similarly, we observe from the same table that 87 per cent of the persons living in semi-pucca houses have their family income less than rupees 300 per month. This shows that most of the persons not receiving education and living in semi-pucca houses have their family income less than rupees 300 per month. Another 10 per cent of the persons living in semi-pucca houses come from the families with income ranging between rupees 300 and 499 per month. Pucca houses in which more than 33 per cent of the "persons not receiving education" live, possess almost all the persons with their family income more than rupees 1000 . In addition 65 per cent of the persons living in pucca houses are from the income group of "less than Rs. 300" and 16 per cent of the persons have their family income Rs. 300-499. The rest of the 8 per cent are from the income group "Rs. 500 to 999 ".

1.5.4 Persons Receiving Vocational Training (Apprentices): More than 84 per cent of the apprentices are from the families with their family income less than Rs. 300 per month [4, Table 8.21]. About 9 per cent are from the income group Rs. 300-499. This indicates that almost all the apprentices are from the lower income groups.

\subsubsection{SUMMARY AND CONCLUSIONS}

The survey reveals that 34.2 per cent of the school-age population in Karachi is in-school. This percentage is much higher than that given by the 1961 Census (about 22 per cent). In the light of the discussion made in this chapter, it is concluded that the smaller percentage given by the census data seems to be more due to under enumeration than due to any other reason.

When compared with the enrolment percentages of other advanced countries, even the comparatively higher percentage given by the survey is conspicuously smaller, indicating how big an effort is still needed to bring up the educational levels in this country in line with the other advanced countries of the world.

A big drop-out of school-going persons after primary grades is a very serious problem and needs an immediate attention of the authorities, so that at least those persons who are already in school must complete their education upto a reasonable standard. 
Compared to males the percentage of in-school females is lower. The difference, however, is less in the lower age groups (i.e., 5-9 years and 10-14 years) indicating almost equal opportunities for males and females in the primary grades. However, the big difference in the age group 15-20 indicates a rapid drop-out of females after primary grades. This discrimination in education exists on the worldwide scale also, but there is a growing tendency for girls to make up a larger percentage of enrolments [12, p. 70].

When the in-school proportions of school-age persons are compared by migrant status it is observed that immigrants have the highest overall percentage as compared to in-migrants and the natives. Similarly, the in-migrants have a slightly higher proportion than the natives.

As was expected, we do not find any clearcut differences among major divisions in regard to school-age persons going to school. In fact major divisions are highly overlapping as regard the socio-economic status of the people living in them. However, in the localities where the proportion of higher income people is greater, there are indications of their having comparatively higher proportions of school-age persons in -school. A positive and direct relationship between income and school enrolment is observed in the Section 1.5: (Economic Characteristics) where we have seen that higher the family income the higher its proportion of school-age persons tends to be in-school. 


\section{REFERENCES}

1. Akhtar, Jamila, "Literacy and Education: Fifth Release from the 1961 Census of Pakistan", Pakistan Development Review, Vol. III, No. 3, Autumu 1963.

2. Directorate of Education, March of Education in Karachi, 1962. (Karachi: Directorate of Education, 1962).

3. Halsey, A.H., Flound Jean and C.A. Anderson, (eds), Education, Economy and Society. (New York: The Free Press of Glencoe, Inc., 1961).

4. Hashmi, Sultan S., M. R. Khan and Karol J. Krotki, The People of Karachi: Data from a Survey. Statistical Papers No. 2. (Karachi: Pakistan Institute of Development Economics, June 1964).

5. Pakistan, Ministry of Education, Report of the Commission on National Education. (Karachi: Manager of Publications, 1959).

6. Pakistan, Office of the Census Commissioner, 1961 District Census Report: Karachi. (Karachi: Office of the Census Commissioner).

7. Pakistan, Office of the Census Commissioner, Population Census of Pakistan, 1961. Census Bulletin No. 3. (Karachi: Office of the Census Commissioner, 1962).

8. Pakistan, Office of the Census Commissioner, Population Census of Pakistan, 1961. Census Bulletin No. 4. (Karachi: Manager of Publications, 1962).

9. Shaikh, A.A., Primary Education: March of Education in Karachi. (Karachi: Directorate of Education, 1962).

10. UNESCO, World Survey of Education. III; Secondary Education. (Paris: United Nations Educational Scientific and Cultural Organization, 1961).

11. United Nations, Compendium of Social Statistics, 1963. Statistical Papers Series K No. 2. (New York: United Nations, 1963).

12. United Nations, 1963 Report on the World Social Situation. (New York: United Nations, 1963). 
Social Characteristics of The People of Karachi

CHAPTER 2

Migrant Status

IMTIAZUDDIN HUSAIN 


\section{CONTENTS}

\section{Chapter 2}

MIGRANT STATUS

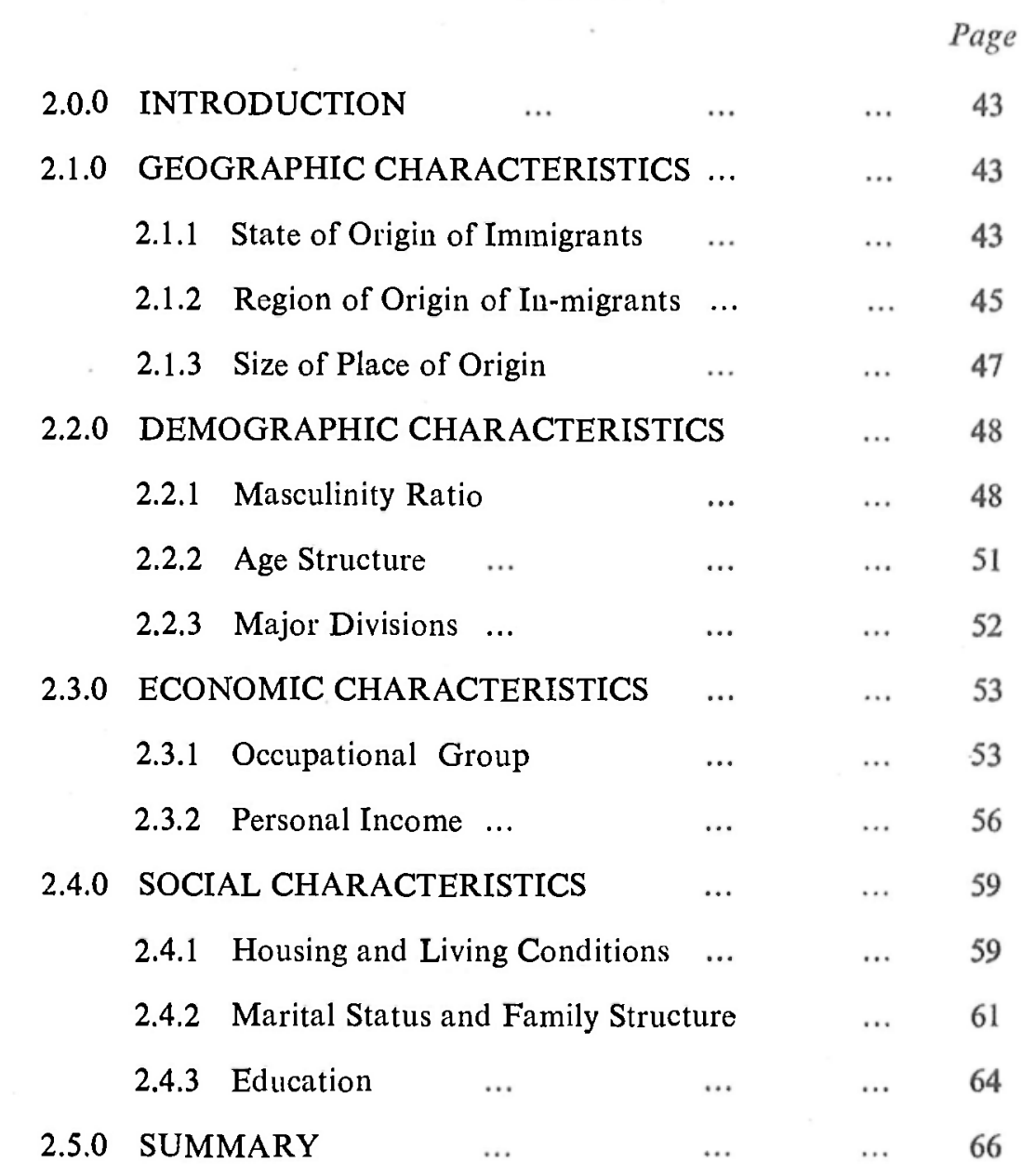




\section{LIST OF TABLES}

Table 2.1 State of Origin of Immigrants $\quad \ldots \quad$.. 44

Table 2.2 Region of Origin of In-migrants $\quad \ldots \quad \ldots \quad \ldots 45$

Table 2.3 Change in Religious Composition Due to Migration: Karachi Corporation and Canton$\begin{array}{llllll}\text { ments } \quad \ldots & \ldots & \ldots & \ldots & 47\end{array}$

Table 2.4 Migrant Status and Size of Locality of Origin 48

Table 2.5 Masculinity Ratios of In-migrants by District of $\begin{array}{lllllll}\text { Origin } & \ldots & \ldots & \ldots & \ldots & 49\end{array}$

Table 2.6 Immigrants: Masculinity Ratios by Year of $\begin{array}{lllllll}\text { Arrival } & \ldots & \ldots & \ldots & \ldots & 50\end{array}$

Table 2.7 In-migrants: Masculinity Ratios by Year of $\begin{array}{llllll}\text { Arrival } & \ldots & \ldots & \ldots & \ldots & 51\end{array}$

Table 2.8 Percentage Distribution of Natives and Migrants $\begin{array}{llllll}\text { by Age } & \ldots & \ldots & \ldots & \ldots & 52\end{array}$

Table 2.9 Percentage Distribution of Natives and Migrants

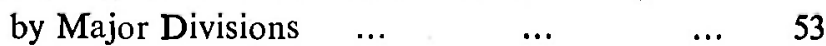

Table 2.10 Percentage Distribution of Occupational Groups $\begin{array}{llllll}\text { by Migrant Status } & \ldots & \ldots & \ldots & 54\end{array}$

Table 2.11 Place of Work/Place of Residence Relation of $\begin{array}{llll}\text { Natives and Migrants ... } & \ldots & \ldots & 55\end{array}$

Table 2.12 Percentage of Unemployed $\quad \ldots \quad$... 56

Table 2.13 Broad Age Groups for Males $\quad \ldots \quad$... 57

Table 2.14 Personal Income of Male Natives, In-migrants $\begin{array}{lllll}\text { and Immigrants } \quad \ldots & \ldots & \ldots & 57\end{array}$

Table 2.15 Occupational Groups of Male Natives, In-migrants $\begin{array}{lllll}\text { and Immigrants } & \ldots & \ldots & \ldots & 58\end{array}$

Table 2.16 Personal Income of Female Natives, In-migrants and Immigrants $\quad \ldots \quad \ldots \quad \ldots \quad \ldots \quad 59$

Table 2.17 Average size of the Household by Migrant Status 59

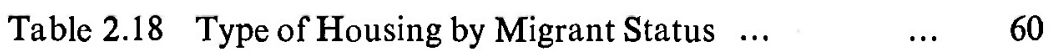

Table 2.19 Migrant Status and House Tenure $\quad \ldots \quad \ldots \quad \ldots \quad 60$

Table 2.20 Migrant Status: Facilities Available in Households 61 
Table 2.21 Marital Status of Males and Migrant Status ... 61

Table 2.22 Marital Status of Females and Migrant Status ... 62

Table 2.23 Migrant Status and Type of Marital Union ... 63

Table 2.24 Migrant Status and Family Classification $\quad \ldots 64$

Table 2.25 School-Age Persons by Migrant Status _.. 64

Table 2.26 School-going Persons by Migrant Status $\quad \ldots 65$

Table 2.27 Percentage of All Persons Aged 5-20 in School by Age Group and Migrant Status $\quad$.. 65 


\section{CHAPTER 2}

\section{MIGRANT STATUS}

\subsubsection{INTRODUCTION}

Study of population by migrant status in relation to place of origin, demographic, economic, and social characteristics has important implications for providing bases for city plannig and improving the economic and social conditions of the people. While interpreting the results, it should be noted that information on migrant status was obtained in the survey [8] for the entire household rather than for an individual. The children of migrants who were born in Karachi and natives who moved into migrant families by marriages were also considered migrants.

The migrants, thus defined, were divided into two categoriesi) in-migrants, whose original place of residence was in Pakistan (excluding Karachi) and ii) immigrants, whose original place of residence was outside Pakistan. As a very large proportion, i.e., 99 per cent of the total immigrants, came from various states of India, analysis in respect of immigrants from countries other than India who form a very small fraction of about one per cent has not been presented separately.

According to our data, as of 1959 immigrants numbered 11,74,000; in-migrants $3,16,400$ and natives $3,00,125$. Immigrants are 65 per cent of the total population, in-migrants 18 per cent of the total population and natives 17 per cent.

The sudden inflow of migrants after the partition of Indo-Pakistan caused problems such as shortage of housing, water supply, transport and other facilities. Many of these problems are being tackled but in order to solve them more effectively, one must know something of the ethnic composition of the population, its background and needs. This chapter is an attempt in this direction.

\subsubsection{GEOGRAPHIC CHARACTERISTICS}

2.1.1 State of Origin of Immigrants: Of the 1,174 thousand immigrants living in Karachi in 1959, 729 thousand or 62 per cent hail from North- 
ern India and 300 thousand or 26 per cent from Western India (see Table 2.1)

TABLE 2.1

STATE OF ORIGIN OF IMMIGRANTS

$\begin{array}{lrrrr}\text { State } & & \text { Number } & \text { Percentage } & \text { Masculinity ratio } \\ \text { All states } & \ldots & 11,74,000 & 100 & 115 \\ \text { Northern }^{\mathrm{a}} & \ldots & 729,075 & 62 & 115 \\ \text { Western }^{\mathrm{b}} & \ldots & 300,625 & 26 & 110 \\ \text { Central }^{\mathrm{c}} & \ldots & 91,200 & 8 & 117 \\ \text { Eastern }^{\mathrm{d}} & \ldots & 22,875 & 2 & 133 \\ \text { Southern }^{\mathrm{e}} & \ldots & 17,175 & 1 & 150 \\ \text { Rest of India } & \ldots & 75 & - & - \\ \text { Other countries }^{\mathrm{f}} & \ldots & 13,175 & 1 & 130\end{array}$

Notes : a) Indian occupied Kashmir, Punjab, Delhi and Uttar Pradesh.

b) Rajasthan, Junagadh, Manavadar and Bombay.

c) Madhya Pradesh and Andhra Pradesh.

d) Bihar, West Bengal and Assam.

e) Mysore, Madras and Kerala.

f) Mainly Iran, Burma, Afghanistan and Ceylon.

Eighty-eight per cent of the immigrants are from Northern and Western India. Karachi has received comparatively few immigrants from Eastern and Southern India. People seem to have migrated in the largest numbers from areas which were most affected by the 1946-47 communal riots. The pressure of these riots was the greatest in Northern and Western India followed by Eastern India. Immigrants to Karachi from Eastern India are very few in number because most of them migrated to East Pakistan. According to the 1951 Pakistan Census figures, 671 thousand out of 701 thousand migrants from Eastern India went over to East Pakistan [15, statement 2-E and p.31]. South India was comparatively peaceful and that is why Karachi received only 17 thousand migrants from that region. A proof supporting the 
above statement can be advanced: Immigrants from Southern India have the highest masculinity ratio (see, Table 2.1), showing that males left behind female members of their families to find better jobs in Karachi.

Other possible factors which might have worked against the South Indians' migration tc Pakistan are:

i) South India is geographically a distant place from Karachi (distance: 1400-1500 miles);

ii) the South Indians are probably less mobile as compared to the groups.

The South Indians who did migrate went to other parts of Pakistan also. By 1951, 18 thousand of these had migrated to all parts of Pakistan. Eleven thousand coming to Karachi, one thousand to East Pakistan and six thousand to West Pakistan [14, p. 29]. But, by 1951 at least, a sizeable majority (61 per cent) of South Indians had come to Karachi.

There are 13,100 immigrants from countries other than India. We have ignored these in the discussions that follow because they constitute only one per cent of all the immigrants. This percentage is too small to make any significant diflerence in the results.

2.1.2 Region of Origin of In-migrants: According to the survey There are 3,16,400 in-migrants in Karachi; of these, 1,24,150 or about 39 par cent are from former N.W.F.P. (see, table below).

TABLE 2.2

REGION OF ORIGIN OF IN-MIGRANTS

\begin{tabular}{|c|c|c|c|c|}
\hline Region & & & Number & Percentage \\
\hline All regions & $\ldots$ & $\ldots$ & $3,16,400$ & 100 \\
\hline Former Sind & $\ldots$ & $\ldots$ & 8,675 & 3 \\
\hline Former Baluchistan & $\ldots$ & $\ldots$ & 13,525 & 4 \\
\hline Former Punjab & $\ldots$ & $\ldots$ & $1,33,875$ & 43 \\
\hline Former N-W.F.P. & $\ldots$ & $\ldots$ & $1,24,150$ & 39 \\
\hline Azad Kashmir & $\ldots$ & $\ldots$ & 6,925 & 2 \\
\hline East Pakistan & $\ldots$ & $\ldots$ & 26,850 & 8 \\
\hline No information & $\ldots$ & $\ldots$ & 2,400 & 1 \\
\hline
\end{tabular}

Source: [8, Table 5.4]]. 
Why don't in-migrants go to nearer industrial/commercial places like Multan, Lyallpur, Lahore or Rawalpindi instead of coming to Karachi? A possible answer is that the wages and other working conditions may be better in Karachi than in other places mentioned above; perhaps that is why in-migrants from far north think it worth taking the added cost (of time and money) in coming to Karachi. Of course, inmigrants may have many other reasons for coming down to Karachi as: Karachi has been a new and faster growing commercial and industrial centre than other cities of Pakistan; with better opportunities of work; Karachi was (upto recently) the Federal Capital of Pakistan.

Only about 22 thousand or 7 per cent of all in-migrants are from former Sind and Baluchistan provinces, the two areas adjacent to Karachi. This situation is quite unlike Bombay where in-migrants from Maharashtra, Mysore and Gujrat (all adjacent provinces) comprise 65 per cent of all in-migrants to Bombay [17, p. 1].

There are 26,850 in-migrants from East Pakistan. Although East Pakistan and former N.W.F.P. are both almost equally distant, i.e., 1000-1200 miles away, it is much easier for a man from former N.W.F.P. to come down to Karachi because it is cheaper and less time-consuming for him than it is for an East Pakistani. Train fares from Rawalpindi or Peshawar to Karachi are about Rs. 30-35; and the journey is over in less than two days. An East Pakistani can reach Karachi by plane or by ship; a plane journey is too costly (tourist fare Rs. 200.00) and a ship journey from East Pakistan, although cheaper, (deck fare Rs. 90.00) takes 8-10 days to reach Karachi.

Mention should be made here of the migration of Caste Hindus, Sikhs and other non-Muslims from Karachi between the year 1947 and 1949. Caste Hindus numbered about 1,74,000 in Karachi in 1941 (see, Table 2.3). These would have increased to about 2,20,000 by 1951 (assuming a birth rate of 40 per 1000 per annum and death rate of 15 per 1000, i.e., a natural increase of 25 per 1000 per annum). But the 1951 Census actually showed only 4,400 Caste Hindus. From the above statements we can conclude that at least 2,15,000 Caste Hindus left Karachi mostly during 1947-49 troubles. Similarly, in 1941 (Table 2.3) there were 12,600 Sikhs, Jains, and persons of other cults (except 
Parsis and Christians). These would have increased to 15,000 by 1951 (assuming the same growth rate as in the previous case), but the 1951 Census actually showed their number as one thousand which means that around 14 thousand Sikhs, Jains and others left Karachi between 1947-49. Thus, in all 2,29,000 non-Muslims (excluding Parsis and Christians) left Karachi as a result of the partition of Indo-Pakistan subcontinent in 1947

TABLE 2.3

CHANGE IN RELIGIOUS COMPOSITION DUE TO MIGRATION KARACHI CORPORATION AND CANTONMENTS

\begin{tabular}{|c|c|c|c|c|}
\hline \multirow{2}{*}{ Community } & & & \multicolumn{2}{|c|}{ Persons } \\
\hline & & & 1941 & 1951 \\
\hline All communitics & $\ldots$ & $\ldots$ & \multicolumn{2}{|c|}{ (in '000') } \\
\hline Muslims & $\ldots$ & $\ldots$ & 153.3 & 967.5 \\
\hline Caste Hindus & $\ldots$ & $\ldots$ & 173.9 & 4.4 \\
\hline Parsis & $\ldots$ & $\ldots$ & 3.7 & 5.0 \\
\hline Sikhs & $\cdots$ & $\ldots$ & 12.6 & 1.0 \\
\hline Christians & $\ldots$ & $\cdots$ & 10.0 & 16.7 \\
\hline Scheduled Castes & $\ldots$ & $\ldots$ & 11.9 & 11.8 \\
\hline
\end{tabular}

Source: [14, Statement 5-B, p. 84].

It seems that (comparing 1941 and 1951 Census figure) Parsis and Christians did not migrate from Karachi; their population has shown normal increase over the decade.

2.1.3 Size of Place of Origin: At the outset names shall be given according to the size of the locality. All localities which have a population of less than 10,000 will be called villages; those with a population ranging from 10,000 to $1,00,000$ will be called towns; and localities with a population of over $1,00,000$ will be termed cities.

Referring to Table 2.4 below we find that 11 per cent of the inmigrants and 38 per cent of the in-migrants are from villages. Similarly, when we look at localities of $1,00,000$ or more, we find that 56 per cent of the immigrants and only 20 per cent of the inmigrants are from such localities. Immigrants were mainly city dwellers and in-migrant village (or town) dwellers before coming to Karachi. 
TABLE 2.4

\section{MIGRANT STATUS AND SIZE OF LOCALITY OF ORIGIN}

\begin{tabular}{lrccc}
\hline Size of locality & \multicolumn{1}{c}{ Immigrants } & \multicolumn{2}{c}{ In-migrants } \\
\hline All sizes & $11,74,100$ & 100 & $3,16,400$ & 100 \\
Less than 10,000 & $1,33,675$ & 11 & $1,20,025$ & 38 \\
Between 10,000 and 50,000 & $1,87,325$ & 16 & 55,600 & 18 \\
Between 50,000 and $1,00,000$ & $1,25,175$ & 11 & 18,300 & 6 \\
Between 100,000 and above & $6,57,700$ & 56 & 64,050 & 20 \\
No information & 70,225 & 6 & 58,245 & 18 \\
\hline
\end{tabular}

Source: For immigrants [8, Table 5.64]. for in-migrants [8, Table 5.60].

But a large majority of immigrants who settled in other parts of Pakistan did not hail from cities. At least 75 per cent of the immigrants to this country came from rural areas of India [10, p. 115].

\subsubsection{DEMOGRAPHIC CHARACTERISTICS}

2.2.1 Masculinity Ratio: Males in Karachi number 9,99,250 and females $8,03,925$. The masculinity ratio comes to 124 . But if we take into account the 37 thousand non-household population which was not covered in the survey, the masculinity ratio would be different from what we have shown. The ratio of different migrant groups is as follows:

$\begin{array}{lll}\text { Immigrants } & \ldots & 115 \\ \text { In-migrants } & \ldots & 187 \\ \text { Natives } & \ldots & 104\end{array}$

The high masculinity ratio of in-migrants is noteworthy. It is also interesting to note that the ratio of in-migrants shows a general decline as the distance between their home district and Karachi decreases (Table 2.5) : 
TABLE 2.5

MASCULINITY RATIOS OF IN-MIGRANTS BY DISTRICTS OF ORIGIN

\begin{tabular}{lc} 
District & $\begin{array}{c}\text { Masculinity } \\
\text { ratio }\end{array}$ \\
Hazara & 236 \\
Rawalpindi & 192 \\
Jhelum & 185 \\
Gujranwala & 118 \\
Lyallpur & 189 \\
Multan and Bahawalpur & 178 \\
Sukkur and Larkana & 93 \\
Hyderabad and Nawabshah & 132 \\
Lasbela & 127 \\
\hline
\end{tabular}

Source: $[8$, Table 5.41$]$.

This tendency is also found among immigrants. Immigrants from nearby areas have lower masculinity ratio and those from the farthest have the highest (Table 2.1). This phenomenon is also observed in most country-to-city migrations in the United States [15, p. 304].

The all Pakistan masculinity ratio is $111[9$, p. 33] and that of West Pakistan is 116 [9, p. 35]. The ratio of immigrants is almost exactly equal to that of West Pakistan. But the ratio of natives is lower than even the all Pakistan figure. This might be due to $i$ ) native male outmigration, ii) greater survival of native females in Karachi.

According to our calculations, Karachi's overall masculinity ratio is 124 but the 1961 Census shows the ratio to be 132. The difference may be due to different universes of Karachi's population and areas. Karachi's ratio is lower than that of Bombay (151) [10], Calcutta (163) [10, p. 44], or Delhi (129) [10, p. 146]. The high masculinity ratio of Indian cities is probably because of in-migration from other parts of India which is a predominately male affair. It may also be due to the higher death rates of female babies and young mothers since there is 
no generally accepted evidence that the $s \in \mathrm{x}$ ratio at birth (105-106) is different in India from other European countries [4, p. 91]. The factors affecting sex ratio of Indian cities are also operative in Karachi.

In the United States, Washington D.C. has higher percentage of women than men. Also, in most cities of Southern United States females greatly outnumber males $[7$, p. 240] bzcause of male migration towards the North, large scale female country-to-city migration, and female longevity.

Sex ratio has an important bearing on many socio-economic conditions prevailing in a metropolis. A scarcity of women at the young adult age, for example, will affect marriage rate and thus the crude birth rates. In addition, school attendance, female employment, amount of prostitution, status of women in the community and many other social conditions are more or less directly related to the sex ratio of a metropolis.

The masculinity ratio of immigrants as well as in-migrants has shown an upward trend as the years have passed. This trend is sharper in the case of in-migrants (Table 2.7). In the case of immigrants (Table 2.6) the ratio was 118 upto 1941 ; then rose a bit during war years (1941-1946). This was perhaps due to the fact that Karachi being the nearest port to Europe served as a good landing and take-off base during the war. Men came here to serve in the army or take up other jobs leaving female family members back home. During 1947-49 the ratio declined due mainly to the migration of a large number of people with their families following partition of the subcontinent. From 1949 onwards, the ratio has been increasing slowly which means more and more immigrant males are leaving behind females in India.

TABLE 2.6

IMMIGRANTS: MASCULINITY RA'TIOS BY YEAR OF ARRIVAL

\begin{tabular}{lrrr}
\hline Year of arrival & Males & Females & $\begin{array}{c}\text { Masculinity } \\
\text { ratio }\end{array}$ \\
\hline Before 1941 & 6,000 & 5,100 & 118 \\
$1941-46$ & 5,600 & 4,650 & 120 \\
1947 & $2,67,325$ & $2,35,350$ & 114 \\
1948 & $1,01,950$ & 88,300 & 115 \\
1949 & 53,900 & 48,750 & 111 \\
1950 & 70,775 & 62,225 & 114 \\
$1951-52$ & 55,350 & 48,000 & 115 \\
$1953-54$ & 32,225 & 25,750 & 125 \\
$1955-56$ & 16,850 & 13,475 & 125 \\
$1957-59$ & 15,375 & 11,450 & 134 \\
\hline
\end{tabular}


The masculinity ratio of in-migrants (Table 2.7 ) has registered a steeper rise, touching 122 in 1947, it rose to 272 by 1959 . The inference which can be drawn is that in-migrant males come here for jobs leaving behind females in large numbers. The masculinity ratio of in-migrants who came here during 1941-46 is also quite high (144). The explanation is the same as cited above in the case of immigrants who came in the same period.

TABLE 2.7

IN-MIGRANTS: MASCULINITY RATIOS BY YEAR OF ARRIVAL

\begin{tabular}{lccc} 
Year of arrival & Males & Females & $\begin{array}{c}\text { Masculinity } \\
\text { ratio }\end{array}$ \\
\hline Before 1941 & 16,975 & 13,825 & 123 \\
$1941-46$ & 11,600 & 8,050 & 144 \\
1947 & 15,900 & 13,075 & 122 \\
1948 & 9,600 & 6,875 & 140 \\
1949 & 10,025 & 6,800 & 147 \\
1950 & 15,475 & 8,650 & 179 \\
$1951-52$ & 23,325 & 12,000 & 194 \\
$153-54$ & 29,350 & 12,500 & 235 \\
$1955-56$ & 31,450 & 12,725 & 247 \\
$1957-59$ & 39,775 & 14,625 & 272 \\
\hline$-\cdots-30$ & & Source: $[8$, Table 5.20$]$.
\end{tabular}

2.2.2 Age Structure: The age structure of the three groups shows some distinct patterns: It seems that Karachi's population has a narrower base compared to East or West Pakistan as children between 0-4 account for about 14 per cent of the total population. The corresponding percentage for East Pakistan is 18 and that for West Pakistan is $16[8$, p. 30]. The difference between the percentages of Karachi and West Pakistan are quite narrow and give rise to the conclusion that Karachi as a whole has fertility no different from rural areas of West Pakistan [13].

Over 50 par cent of natives and over 52 per cent of immigrants are aged 19 years or less (Table 2.8). It can, thus, safely be said that the 
CBR of both these groups is quite high as we have a fairly large percentage of the population in lower brackets. In-migrants have about 42 per cent among their group under 19 age bracket. The in-migrants seem to be more age selective than others. This statement gains weight as we look at the $20-59$ brackets: 50 per cent of the in-migrants being concentrated here; as a comparison about 43 per cent natives and 43 per cent immigrants are found in these brackets.

TABLE 2.8

\section{PERCENTAGE DISTRIBUTION OF NATIVES AND MIGRANTS BY AGE}

\begin{tabular}{l|ccc}
\hline Age group & \multicolumn{3}{c}{ Migrant status } \\
\hline All ages & Natives & In-migrants & Immigrants \\
\hline $0-4$ & 100.0 & 100.0 & 100.0 \\
$5-19$ & 15.0 & 13.6 & 15.6 \\
$20-39$ & 35.6 & 28.3 & 36.7 \\
$40-59$ & 28.9 & 45.9 & 30.8 \\
60 and over & 14.6 & 10.2 & 12.5 \\
\hline-2.9 & & 2.0 & 4.3 \\
\hline
\end{tabular}

Natives have the largest proportion of older people (those over 60 ) and in-migrants the smallest. In-migrants mostly ccnsist of people in the working age group. Of all the groups, the inmigrants have the largest proportion of potential man power.

2.2.3 Major Divisions: When we refer to Table 2.9, we find that natives, in-migrants and immigrants are more or less evenly distributed in commercial area and labour area. But natives predominate in rural and lower residential areas. They have been living in these areas for decades mainly bacause they were not better off than the Hindus prior to Partition of 1947. They were pushed to these areas by economic forces. It is interesting to note that very few immigrants or in-migrants settled in rural areas of Karachi. 
In-migrants dominate the non-contiguous area. They are also found in fairly large numbers in industrial area-most probably working as labourers in nearby factories.

A larger percentage of natives as well as of in-migrants is living in upper residential area compared with middle residential area. Two possible reasons can be given for this phenomenon: $i$ ) upper residential area includes a large number of jiggi-dwellers also who were counted as upper class residents, ii) among natives and in-migrants only small proportions, i.e., 5 per cent and 12 per cent respectively, live in middle residential area.

Immigrants dominate the middle residential areas. These areas are the new societies and colonies constructed after Partition. Immigrants are almost totally absent from non-contiguous and rural areas.

TABLE 2.9

PERCENTAGE DISTRIBUTION OF NATIVES AND MIGRANTS BY MAJOR DIVISIONS

\begin{tabular}{|c|c|c|c|c|c|c|}
\hline \multirow{2}{*}{ Major divisions } & \multicolumn{2}{|l|}{ Natives } & \multicolumn{2}{|c|}{ In-migrants } & \multicolumn{2}{|c|}{ Immigrants } \\
\hline & Number & $\%$ & Number & $\%$ & Number & $\%$ \\
\hline All divisions & $3,00,125$ & 100 & $3,16,400$ & 100 & $11,74,100$ & 100 \\
\hline Commercial area & 63,000 & 21 & 67,652 & 21 & $2,60,741$ & 22 \\
\hline Industrial area & 9,995 & 3 & 45,292 & 14 & 59,642 & 5 \\
\hline Lower residential & 84,252 & 29 & 36,213 & 11 & $1,23,552$ & 11 \\
\hline Middle residential & 15,293 & 5 & 38,329 & 12 & $4,14,186$ & 35 \\
\hline Upper residential & 23,400 & 8 & 54,389 & 17 & $1,13,766$ & 10 \\
\hline Non-contiguous area & {$[2,146$} & 1 & 26,905 & 8 & $\{20,218$ & 2 \\
\hline Labour area & 40,157 & 13 & 42,973 & 14 & $1,70,993$ & 15 \\
\hline Rural area & 62,406 & 20 & 8,480 & 3 & 6,763 & - \\
\hline
\end{tabular}

\subsubsection{ECONOMIC CHARACTERISTICS}

2.3.1 Occupational Groups: We have classified all the occupations into three major heads: 
1) Professional and managerial: These include all jobs which involve administration or research. These jobs have high esteem because they involve a lot of training and also because income in these jobs are the highest.

2) Clerical and skilled workers include clerks and other workers like tailors, plumbers, carpenters, etc. These jobs require a good deal of training but do not carry much prestige or esteem, so come next in rank to professionals and managers.

3) Others: This category includes all unskilled and semiskilled workers as well as servants, farmers, fishermen, hawkers, peons, etc. These jobs require some training and carry the lowest prestige.

It is hard to attach a status tag but one can get a fair idea of one's status in Karachi by the occupations held, the income earned, education acquired, and housing. A relatively large share of the better occupations (type 1) goes to immigrants, (see, Table 2.10). Next come in-migrants and then natives. Natives are not found in large proportions in clerical field only 10 per cent of natives have such jobs, as compared to 19 per cent of the in-migrants. But natives are found in larger proportion (79 per cent) in the lowest pay/esteem jobs.

TABLE 2.10

PERCENTAGE DISTRIBUTION OF OCCUPATIONAL GROUPS BY MIGRANT STATUS

\begin{tabular}{|c|c|c|c|c|}
\hline Type & Occupational group & Natives & In-migrant & Immigrants \\
\hline - & All occupations & 100 & 100 & 100 \\
\hline 1 & $\begin{array}{l}\text { Professional and } \\
\text { managers }\end{array}$ & 11 & 6 & 14 \\
\hline II & $\begin{array}{l}\text { Clerical, skilled } \\
\text { workers }\end{array}$ & 10 & 19 & 22 \\
\hline III & Others & 79 & 75 & 64 \\
\hline
\end{tabular}

Source: $[8$, Table 5.01$]$ 
Some idea of the work-place and place of residence relationship will be got from the fact that 45 per cent of the immigrants, 27 per cent of the in-migrants and 24 per cent of the natives live in a chunk which is not contiguous to their place of work (see, Table 2.11). In other words, immigrants go the farthest for their jobs in comparison with the other two groups. This may be one of the (many) reasons why immigrants have better jobs.

TABLE 2.11

\section{PLACE OF WORK/PLACE OF RESIDENCE RELATION OF} NATIVES AND MIGRANTS

\begin{tabular}{|c|c|c|c|}
\hline $\begin{array}{l}\text { Work-place and residence } \\
\text { relation }\end{array}$ & Na tives & In-migrants & Immigrants \\
\hline All relations & 100 & 100 & 100 \\
\hline Work in own household & 1 & 2 & 3 \\
\hline Work in same chunk & 29 & 38 & 18 \\
\hline Work in adjacent chunk & 7 & 16 & 7 \\
\hline Work in non-contiguous chunk & 24 & 27 & $\ldots 45 \ldots$ \\
\hline No fixed place of work & 37 & 16 & 24 \\
\hline No information & 2 & 1 & 3 \\
\hline
\end{tabular}

Source: [8, Table 5.16].

Natives and in-migrants perhaps do not get many good jobs because they choose their place of work close to their place of residence. The percantage of the in-migrants who have their place of work in chunks adjacent to the ones in which they live is 16 . These percentages among natives and immigrants are 7 and 7 respectively.

Turning to unemployment we find that it is the highest among natives, being 3.8 per cent of the total number of natives in ages 15-64 (Table 2.12). 
Two reasons can be tentatively put forward to explain the high unemployment among natives. One is that in-migrants are displacing natives from their jobs by accepting lower wages. Another one is that the industrial and commercial establishments in and around Karachi demand complex skills which are not being supplied by the natives, a majority of whom has an agricultural background and a fairly large parcentage of whom (27 par cent) actually lives in the rural chunks namely Gabopat, Gujro, Konkar, Thano, and Ibrahim Hydri 1 .

But in-migrants also show a fairly high unemployment figure ( 3 per cent), though not much different from the immigrants. This percentage of reported unemployment (we are ignoring undeclared unemployment) raises a question: did the in-migrants pour into Karachi without much knowledge of the working conditions here or without much assessment of their own abilities? An indication of a positive answer can be found when we note that in-migrant males have the lowest personal income compared with immigrants and natives (see, next sub-section)2.

TABLE 2.12

PERCENTAGE OF UNEMPLOYED

\begin{tabular}{lrcc}
\hline Migrant status & $\begin{array}{c}\text { Working age } \\
15-64\end{array}$ & Unemployed & Percentage \\
\hline Natives & 84,825 & 3,250 & 3.8 \\
In-migrants & $1,49,150$ & 4,550 & 3.1 \\
Immigrants & $3,53,950$ & 10,750 & 3.0 \\
\hline & & \multicolumn{2}{r}{ Source: [8, Table 5.01]. }
\end{tabular}

2.3.2 Personal Income: Forty-nine per cent of the total population of natives, 33 per cent of the in-migrants and 50 per cent of the immigrants are in the "no income group". This group consists mainly of and above 64 age groups, the percentage of in-migrants in the $0-14$ persons in the $0-14$ and above 64 age groups is low mainly because

1. Percentage calculated from [8, Table 5.14]

2. The hypothesis that in-migrants are under-cutting wages of natives gains weight in the light of this statement. The in-migrants are lowest paid perhaps because they accept low wages. Of course, there must be other reasons for their being the lowest paid. 
in-migrants fall in the 15-64 age brackets. In-migration is apparently more age selective than immigration. Seventy-two per cent of inmigrants are in the 15-64 age brackets, while only 44 per cent of the native and only 45 per cent of the immigrants are in the 15-64 age brackets (Table 2.13).In other words, among the in-migrants a larger percentage is of working age as compared to natives or immigrants. Also, a larger percentage is gainfully employed compared to natives or immigrants.

TABLE 2.13 BROAD AGE GROUPS FOR MALES

\begin{tabular}{l|r|r|r|r|r|r}
\hline \multirow{2}{*}{ Age group } & \multicolumn{2}{|c|}{ Natives } & \multicolumn{2}{c|}{ In-migrants } & \multicolumn{2}{c}{ Immigrants } \\
\cline { 2 - 7 } & Number & $\%$ & Number & $\%$ & Number & $\%$ \\
\hline All ages & $1,53,025$ & 100 & $2,06,150$ & 100 & $6,28,400$ & 100 \\
$0-14$ & 63,925 & 42 & 55,600 & 27 & $2,61,300$ & 42 \\
$15-64$ & 84,825 & 55 & $1,49,150$ & 72 & $3,53,950$ & 56 \\
65 and over & 4,275 & 3 & 1,400 & 1 & 13,150 & 2 \\
\hline
\end{tabular}

Of the total number of earners 58 per cent among natives, 47 per cent among immigrants and 60 per cent among in-migrants are in the three lowest income groups (Rs. 1-49; Rs. 50-75; Rs. 75-99]. Of the people earning less than Rs. 100 per month, the percentage of inmigrants is the highest. Natives are not very much better off than inmigrants but immigrants have a significantly lower percentage of earners with less than Rs. 100 per month.

TABLE 2.14

PERSONAL INCOME OF MALE NATIVES, IN-MIGRANTS AND IMMIGRANTS

\begin{tabular}{l|rr|rrrrr}
\hline \multirow{2}{*}{ Income group } & \multicolumn{2}{c}{ Natives } & \multicolumn{2}{c|}{ In-migrants } & \multicolumn{2}{c}{ Immigrants } \\
\cline { 2 - 7 } & Number & $\%$ & Number & $\%$ & Number & $\%$ \\
\hline All groups & $1,53,025$ & 100 & $2,06,150$ & 100 & $6,28,400$ & 100 \\
Non-earners & 75,175 & 49 & 68,125 & 33 & $3,16,550$ & 50 \\
Earners & 77,850 & 51 & $1,38,025$ & 67 & $3,11,850$ & 50 \\
\hline Earners & 77,850 & 100 & $1,38,025$ & 100 & $3,11,850$ & 100 \\
Rs. 1-49 & 7,875 & 10 & 6,150 & 4 & 18,025 & 6 \\
Rs. 50-74 & 23,755 & 30 & 43,825 & 32 & 74,100 & 24 \\
Rs. 75-99 & 14,300 & 18 & 33,725 & 24 & 53,850 & 17 \\
Rs. 100-124 & 12,775 & 17 & 24,650 & 18 & 58,850 & 19 \\
Rs. 125-149 & 2,125 & 3 & 5,250 & 4 & 18,650 & 6 \\
Rs. 150-199 & 6,300 & 8 & 9,525 & 7 & 34,550 & 11 \\
Rs. 200-299 & 4,325 & 6 & 7,725 & 6 & 23,625 & 8 \\
Rs. 300-499 & 3,100 & 4 & 3,650 & 3 & 16,375 & 5 \\
Rs. 500-999 & 1,800 & 2 & 1,725 & 1 & 6,325 & 2 \\
Rs. 1000 and over & 300 & 0.4 & 950 & 0.6 & 3,925 & 1 \\
No information & 1,375 & 1.6 & 850 & 0.4 & 3,975 & 1 \\
\hline
\end{tabular}


In-migrants fair badly in the two highest income groups also (Rs. 500-999; Rs. 1000-and-above). About 1.6 per cent of in-migrants have incomes of Rs. 500-and-over while the corresponding percentage for natives is 2.4 and for immigrants 3.0 .

Compared to immigrants and natives, the in-migrants have the largest percentage of workers but earn the least, because a majority of them are in low paid jobs. In-migrants' percentage in low paid jobs (like semi-skilled, unskilled and servants)is prominent (Table 2.15). Among the in-migrants of working age (15-64) 50 per cent are classified as semi-skilled, unskilled and in servant category. The corresponding percentage among immigrants is 23 .

TABLE 2.15

OCCUPATIONAL GROUPS OF MALE NATIVES, IN-MIGRANTS AND IMMIGRANTS

\begin{tabular}{l|rrrrrr}
$\begin{array}{l}\text { Occupational } \\
\text { groups }\end{array}$ & Number & $\%$ & Number & $\%$ & Number & $\%$ \\
\hline All occupations & 81,175 & 100 & $1,42,575$ & 100 & $3,17,650$ & 100 \\
$\begin{array}{l}\text { Semi-skilled and } \\
\text { unskillled }\end{array}$ & 17,475 & 21.5 & 45,200 & 31.7 & 44,100 & 13.9 \\
\begin{tabular}{l} 
Servants, etc. \\
\hline
\end{tabular} & 5,900 & 7.3 & 26,475 & 18.6 & 28,875 & 9.1 \\
\hline
\end{tabular}

From Table 2.14 we have calculated that all male earners, natives, in-migrants and immigrants, number about 5,28,000. Those who earn less than Rs. 200 par month comprise 85 per cent of all earners. Fazalbhoy's estimate for Karachi puts the percentage for such earners at more than $66[6]$.

When we look at female earners (Table 2.16) we find that female earners comprise 4.7 per cent of all earners in Karachi. Native females predominate in the number and percentage of high earners (those earnings Rs. 500 and more). In-migrant female earners are worst off with regard to income. 
TABLE 2.16

PERSONAL INCOME OF FEMALE NATIVES, IN-MIGRANTS AND IMMIGRANTS

\begin{tabular}{|c|c|c|c|c|c|c|}
\hline \multirow{2}{*}{ Income group } & \multicolumn{2}{|c|}{ Natives } & \multicolumn{2}{|c|}{ In-migrants } & \multicolumn{2}{|c|}{ Immigrants } \\
\hline & Number & $\%$ & Number & $\%$ & Number & $\%$ \\
\hline All earners & 6,975 & 100 & 3,725 & 100 & 15,675 & 100 \\
\hline Rs. $1-199$ & 5,650 & 81.0 & 3,350 & 90.0 & 13,625 & 86.6 \\
\hline Rs. $200-499$ & 850 & 12.0 & 275 & 7.0 & 1,325 & 8.4 \\
\hline Rs. 500 and above & 375 & 5.4 & 50 & 1.5 & 300 & 2.0 \\
\hline Unknown & 100 & 1.6 & 50 & 1.5 & 425 & 3.0 \\
\hline
\end{tabular}

\subsubsection{SOCIAI, CHARACTERISTICS}

2.4.1 Housing and Living Conditions: In this sub-section we shall discuss which migrant group is better off with regard to size, type, tenure and facilities in a household.

TABLE 2.17

AVERAGE SIZE OF THE HOUSEHOLD BY MIGRANT STATUS

\begin{tabular}{lrcc} 
& $\begin{array}{c}\text { Number of } \\
\text { households }\end{array}$ & $\begin{array}{c}\text { Number of } \\
\text { persons }\end{array}$ & $\begin{array}{c}\text { Average } \\
\text { size }\end{array}$ \\
\hline All status & $4,09,325$ & $18,03,175$ & 4.4 \\
Natives & 60,350 & $3,00,125$ & 5.0 \\
In-migrants & 93,925 & $3,16,400$ & 3.4 \\
Immigrants & $2,54,725$ & $11,74,100$ & 4.6 \\
\hline
\end{tabular}

Source: [8, Table 7.05].

Table 2.17 shows the average size of a household by migrant status. Among the people of Karachi, natives have larger-sized household than in-migrants or immigrants. In-migrant household size is the smallest; this is perhaps due to the fact that a large number of inmigrant leave behind their families in the upcountry and live here alone or with friends. Native households are more crowded, as compared with the other two groups. 
A survey ${ }^{3}$ of shelterless people [2, p. 7] conducted by Nazir Ahmad in 1959 shows that the average size of a shelterless family (84 per cent of these baing immigrant) is 5 . This corresponds with the overall size of 4.6 for immigrants which we got from our data. When we consider type of housing, a larger percentage of immigrants live in pucca houses as compared to natives or in-migrants. A greater percentage among natives live in juggies compared to in-migrants or immigrants. (Table 2.18). Thus, with regard to type of housing, immigrants are best and natives are worst off.

TABLE 2.18

TYPE OF HOUSING BY MIGRANT STATUS

\begin{tabular}{l|r|r|r|r|r|r}
\hline \multirow{2}{*}{ Type of house } & \multicolumn{2}{c}{ Natives } & \multicolumn{2}{c}{ In-migrants } & \multicolumn{2}{c}{ Immigra nts } \\
\cline { 2 - 7 } & Number & $\%$ & Number & $\%$ & Number & $\%$ \\
\hline All types & $3,00,125$ & 100 & $3,16,400$ & 100 & $11,74,100$ & 100 \\
Pucca & 91,650 & 30 & $1,17,800$ & 37 & $5,92,525$ & 50 \\
Semi-pucca & 70,725 & 24 & 76,725 & 24 & $2,07,550$ & 18 \\
Juggi and others & $1,37,750$ & 46 & $1,21,875$ & 39 & $3,74,025$ & 32 \\
\hline & & & & & & Source: $[8$, Table 7.1$] 10$.
\end{tabular}

Migrant groups rent houses more than natives. Among migrants, in-migrants rented houses more than immigrants (see, Table 2.19).

TABLE 2.19

MIGRANT STATUS AND HOUSE TENURE

\begin{tabular}{l|r|rrr}
\hline \multicolumn{1}{l|}{ Migrant status } & Using rented houses & Living in own house \\
\hline & Number & $\%$ & Number & $\%$ \\
\hline Natives & 88,900 & 30 & $2,10,450$ & 70 \\
In-migrants & $1,78,925$ & 58 & $1,33,650$ & 42 \\
Immigrants & $5,36,500$ & 46 & $6,36,125$ & 54 \\
\hline *includes rent-free houses. & & & Source: $[8$, Table 7.20$]$.
\end{tabular}

Why do in-migrants live in rented houses more than immigrants? Three possible answers can be forwarded:

a) In-migrants came later than immigrants, and were normally not entitled to evacuee houses;

3 The survey covered 1,19,000 families. 
b) In-migrants have lower personal incomes compared to immigrants and so cannot afford to build houses of their own;

c) Some in-migrants have their own houses in their places of origin and do not find it necessary to build new ones in Karachi as they may be working here temporarily. But, owning a house may not be a credit: after all 35 per cent o1 all owned houses are juggies-dwellings made of straw, bamboo, canvas and/or some mud plaster.

When we look at facilities in house we find that water and electricity are available to the greatest degree in immigrant households; inmigrant households come next and natives are last (Table 2.20).

TABLE 2.20

MIGRANT STATUS: FACILITIES AVAILABLE IN HOUSEHOLDS

\begin{tabular}{|c|c|c|c|c|c|c|c|c|}
\hline \multirow{2}{*}{$\begin{array}{l}\text { Migrant } \\
\text { status }\end{array}$} & \multirow{2}{*}{$\begin{array}{c}\text { All } \\
\text { persons }\end{array}$} & $\begin{array}{c}\text { Both water \& } \\
\text { electricity }\end{array}$ & \multicolumn{2}{|c|}{$\begin{array}{l}\text { Either water or } \\
\text { electricity }\end{array}$} & \multicolumn{2}{|c|}{$\begin{array}{l}\text { Neither water } \\
\text { nor electricity }\end{array}$} & \multicolumn{2}{|c|}{$\begin{array}{c}\text { Other } \\
\text { facilities }\end{array}$} \\
\hline & & Number $\%$ & Number & $\%$ & Number & $\%$ & Number & $\%$ \\
\hline Natives & $3,00,125$ & $38,525 \quad 13$ & 25,550 & 8 & $2,35,775$ & 79 & 275 & - \\
\hline $\begin{array}{l}\text { In-mig- } \\
\text { rants }\end{array}$ & $3,16,400$ & $53,250 \quad 17$ & 30,650 & 10 & $2,32,225$ & 73 & 275 & 一 \\
\hline Immigrant & $11,74,100$ & $2,60,725 \quad 22$ & 97,250 & 9 & $8,14,500$ & 69 & 1,625 & - \\
\hline
\end{tabular}

Source: $[8$, Table 7.30$]$.

In sum, taking all the indices of housing conditions, i.e., size of household, type of houses, tenure and facilities, migrants, live better than natives and among migrants, immigrants live better than inmigrants.

2.4.2 Marital Status and Family Structure: A higher percentage of single men is found among immigrants as compared to in-migrants or natives. The widowers' percentage also seems highest in the case of immigrants (Table 2.21).

TABLE 2.21

MARITAL STATUS OF MALES AND MIGRANT STATUS

\begin{tabular}{|c|c|c|c|c|c|c|}
\hline \multirow{2}{*}{ Marital status } & \multicolumn{2}{|c|}{ Natives } & \multicolumn{2}{|c|}{ In-migrants } & \multicolumn{2}{|c|}{ Immigrants } \\
\hline & Number & $\%$ & Number & $\%$ & Number & $\%$ \\
\hline $\begin{array}{l}\text { All status } \\
\text { Single } \\
\text { Married } \\
\text { Widowed } \\
\text { Divorced and separated }\end{array}$ & $\begin{array}{r}1,53,025 \\
90,300 \\
58,050 \\
4,175 \\
500\end{array}$ & $\begin{array}{r}100 \\
59 \\
38 \\
3 \\
*\end{array}$ & $\begin{array}{r}2,06,150 \\
1,17,125 \\
84,975 \\
3,975 \\
75\end{array}$ & $\begin{array}{r}100 \\
57 \\
41 \\
2 \\
*\end{array}$ & $\begin{array}{r}6,28,400 \\
3,78,275 \\
2,26,625 \\
22,000 \\
1,500\end{array}$ & $\begin{array}{r}100 \\
60 \\
36 \\
4\end{array}$ \\
\hline
\end{tabular}

* denotes percentages less than 0.5

Source: [8, Table 1.22]. 
It is obvious that almost all of those males who are under 15 are single; so if there are more children in a group, the number of single persons increases. The percentage of single men among immigrants and natives is high mainly for this reason. In-migrants have a lower percentage of single persons among them because they have fewer persons 0-14 in their group at Karachi (see, Table 2.13).

When we turn to females, we find the same theme, i.e., highest percentage of single women among immigrants. Both natives and immigrants have a higher porcentage of widows compared to in-migrants. Here, the possible explanation may be that Muslim widows from other parts of Pakistan stay on in their hometowns and do not normally migrate to Karachi.

It can be seen by comparing Tables 2.21 and 2.22 that the percentage of females (out of all females) who are married is higher in all the three groups compared to males. Also, there are more widows than widowers in all the groups. Widow re-marriage seems to be less common compared to widower re-marriage. Native females have highest percentage of divorced and separated.

TABLE 2.22

\section{MARITAL STATUS OF FEMALES AND MIGRANT} STATUS

\begin{tabular}{|c|c|c|c|c|c|c|}
\hline \multirow{2}{*}{ Marital status } & \multicolumn{2}{|c|}{ Natives } & \multicolumn{2}{|c|}{ In-migrants } & \multicolumn{2}{|c|}{ Immigrants } \\
\hline & Number & $\%$ & Number & $\%$ & Number & $\%$ \\
\hline All status & $1,47,100$ & 100 & $1,10,250$ & 100 & $5,45,700$ & 100 \\
\hline Single & 74,250 & 50 & 52,800 & 48 & $2,76,500$ & 51 \\
\hline Married & 58,600 & 40 & 52,675 & 48 & $2,20,550$ & 40 \\
\hline Widowed & 13,325 & 9 & 4,600 & 4 & 46,975 & 9 \\
\hline Divorced and separated & 925 & 1 & 175 & * & 1,675 & * \\
\hline
\end{tabular}

* denotes percentage less than 0.5 . Source: [8, Table 1.22$]$. 
In Karachi almost all marital unions are monogamous. Immigrants are 99.5 per cent monogamous, in-migrants 99.3 and natives 99.3 per cent monogamous (Table 2.23).

Although Islam permits plural marriages, we witness monogamous unions on a large scale mainly because men cannot afford the cconomic burden of an additional wife and children by her. That is one of the many reasons why natives, in-migrants and immigrants stick to one wife. Shortage of houses and fear of tension between two or more wives may also hinder plural marriages.

TABLE 2.23

MIGRANT STATUS AND TYPE OF MARITAL UNION

\begin{tabular}{lrr|rrr|r}
\hline \multirow{2}{*}{ Migrant status } & \multicolumn{2}{|c|}{ All couples } & \multicolumn{2}{c|}{ Monogamous } & \multicolumn{2}{c}{ Polygynous } \\
\cline { 2 - 7 } & Number & $\%$ & Number & $\%$ & Number & $\%$ \\
\hline All status & $3,21,075$ & 100 & $3,18,625$ & 99.2 & 2,450 & 0.8 \\
Natives & 56,125 & 100 & 55,150 & 98.3 & 975 & 1.7 \\
In-migrants & 51,150 & 100 & 50,775 & 99.3 & 375 & 0.7 \\
Immigrants & $2,13,625$ & 100 & $2,12,725$ & 99.5 & 1,100 & 0.5 \\
No information & 175 & 100 & 175 & 100 & - & - \\
\hline
\end{tabular}

Nuclear family system is quite common among natives and immigrants and less so among in-migrants. The percentage of nuclear families among in-migrants is low mainly because many in-migrant males leave their families, come to Karachi and stay with relatives or friends. 73,300 or 23 per cent of all in-migrants live as members of non-family type persons that is those who do not form a family by themselves. This figure is very high as compared to that of natives or immigrants, (Table 2.24).

It is worth-noting that extended or joint familics are not very popular in any migrant group. This may be due to: $a$ ) very limited living space; $b$ ) desire for independent living; $c$ ) lack of financial means to support other relatives. 
We do not have information about the migrant status of 11,825 non-family type persons.

TABLE 2.24

MIGRANT STATUS AND FAMILY CLASSIFICATION

\begin{tabular}{|c|c|c|c|c|c|c|c|c|}
\hline \multirow{2}{*}{ Family classification } & \multicolumn{2}{|c|}{ Natives } & \multicolumn{2}{|c|}{ In-migrants } & \multicolumn{2}{|c|}{ Immigrants } & \multicolumn{2}{|c|}{$\begin{array}{c}\text { No infornia- } \\
\text { tion }\end{array}$} \\
\hline & Number & $\%$ & Number & $\ddot{\%}$ & $\overrightarrow{\text { Number }}$ & $\%$ & Number & $\%$ \\
\hline All classifications & $3,00,125$ & 100 & $3,16,400$ & 100 & $1,174,100$ & 100 & 12,550 & 100 \\
\hline Nuclear & $1,82,450$ & 61 & $1,52,375$ & 48 & $7,46,250$ & 64 & 725 & 6 \\
\hline Extended & 46,375 & 15 & 56,900 & 18 & $2,09,975$ & 18 & - & 一 \\
\hline Joint & 63,975 & 21 & 33,825 & 11 & $1,74,300$ & 15 & - & 一 \\
\hline Non-family type & 7,325 & 3 & 73,300 & 23 & 43,575 & 3 & 11,825 & 94 \\
\hline
\end{tabular}

2.4.3. Education: Out of $7,08,000$ persons of school age (i.e., age 5-20) $1,19,775$ are natives, $1,09,800$ are in-migrants and 4,74,250 immigrants (Table 2.25). We do not have information about 3,975 people.

TABLE 2.25

SCHOOL-AGE PERSONS BY MIGRANT STATUS

\begin{tabular}{lcc}
\hline Migrant status & Number & Percentage \\
\hline All status & $7,08,000$ & 100 \\
Natives & $1,19,775$ & $17(17)$ \\
In-migrants & $1,09,800$ & $16(18)$ \\
Immigrants & $4,74,250$ & $67(65)$ \\
No information & 3,975 & $x(x)$ \\
\hline
\end{tabular}

Nore: $\mathrm{X}$ denotes percentage below one; figures in parentheses in Column (3) Source: [8, Table 1.21]. refer to percentages in the total allstatus population. 
When we observe the table, we find that in-migrants have a lower proportion of persons 5-20 than natives or immigrants. Immigrants have the highest proportion of persons aged 5-20. So immigrants have an initial advantage as far as the school-going population figures are concerned, that gave immigrants a greater proportion of potential students, compared to natives or in-migrants.

In the overall population of 7,08,000 in age groups 5-20, 2,41,715 or 34 per cent are going to school and the rest are not going. For both natives and in-migrants the percentage attending school comes to 22 . Forty per cent of the immigrants aged 5-20 go to school. Immigrants, then, are the most particular about school-going (Table 2.26).

TABLE 2.26

SCHOOL-GOING PERSONS BY MIGRANT STATUS

\begin{tabular}{lccc} 
Migrant status & $\begin{array}{c}\text { Number of } \\
\text { school-going } \\
\text { persons }\end{array}$ & $\begin{array}{c}\text { Number of } \\
\text { school-age } \\
\text { persons }\end{array}$ & Percentage \\
\hline All status & $2,41,975$ & $7,08,000$ & 34 \\
Natives & 26,275 & $1,19,775$ & 22 \\
In-migrants & 24,475 & $1,09,800$ & 22 \\
Immigrants & $1,91,050$ & $4,74,250$ & 40 \\
No information & 175 & - & - \\
\hline & & Source: [8, Table 8.01].
\end{tabular}

TABLE 2.27

PERCENTAGE OF ALL PERSONS AGED 5-20 IN SCHOOL BY AGE GROUP AND MIGRANT STATUS

\begin{tabular}{|c|c|c|c|c|c|c|}
\hline \multirow{2}{*}{ Age groups } & \multicolumn{2}{|c|}{ Natives } & \multicolumn{2}{|c|}{ In-migrants } & \multicolumn{2}{|c|}{ Immigrants } \\
\hline & Males & Females & Males & Females & Males & Females \\
\hline $\begin{array}{c}\text { All ages } \\
(5-20)\end{array}$ & 27 & 16 & 25 & 19 & 46 & 34 \\
\hline $5-9$ & 27 & 18 & 31 & 23 & 44 & 38 \\
\hline $10-14$ & 41 & 23 & 45 & 29 & 65 & 50 \\
\hline $15-20$ & 14 & 7 & 12 & 7 & 31 & 14 \\
\hline
\end{tabular}


Referring to Table 2.27 we find that males go to school more than females and this is true of all the three groups. Immigrant females have better score in terms of school-going than native or in-migrants males. Immigrant males percentage of those who attend school is twice that of natives or in-migrants. The percentage among immigrants is high possibly due to the following reasons: $i$ ) better economic condition; ii) more school facilities in their localities; iii) family traditions-inducing individuals to study. But the figure for in-migrants may be low because in-migrants come to Karachi mainly for job and educationseeking may be of secondary importance to them. This factor perhaps has affected their sample.

When we consider school-going persons by selected age groups, we find that it is highest in ages 10-14 for both sexes as well as native and the two migrant groups. In ages $15-20$ there is a sharp decline in both sexes and all groups. This may be due to the fact that a large number of boys who pass matric start seeking work and a large number of girls are married off. A greater percentage of natives and migrants go to school in ages 5-9 than in 15-20.

In sum, we find that education, is quite limited in Karachionly 34 per cent of eligible boys and girls attend school. Immigrants attend school more than others. Within each group males attend more than females but when we compare one group with the other we find that immigrant females beat even native and in-migrant males in school attendance. For all the three groups school attendance is at its peak between ages 10-14.

\subsubsection{SUMMARY}

A majority (62 per cent) of immigrants to Karachi are from Northern India but a sizeable portion of them has also come here from Western India. There are very few immigrants from South India. It seems that immigrants came from those areas which were worst hit by the Partition riots of 1946-47. The pressure of these riots was the greatest in Northern India followed by Eastern and Western India. Karachi has received 
fewer immigrants, comparatively, from Eastern India because most of the riot affected emigrant from that area went to East Pakistan which was nearer for them.

In-migrants to Karachi are mostly from former Punjab and former North-West Frontier Province. Punjab has a larger and denser population so the fact that it sent $1,33,825$ migrants to Karachi is not much significant. Of greater imporiance is the fact that former N-W.F.P. sent 1,24,150 migrants to Karachi. These form a bigger portion of its total population. In-migrants mostly come for jobs in Karachi.

The masculinity ratio of the immigrants (115) is lower than that of the in-migrants (187). It is the lowest for natives (104). But one fact holds true for both in-migrants and immigrants: As the distance of the migrants' place of origin from Karachi increases so dces the masculinity ratio. Long distance migrants are predominantly masculine.

The masculinity ratio of immigrants as well as of in-migrants has shown an upward trend as the years have passed. This trend is sharper in the case of in-migrants. This means that more and more immigrants and in-migrants are leaving their female family members back home, and are coming to Karachi alone or with the lapse of time the immigrants get settled and they either get married or fetch their families.

Immigrants have the largest proportion of people under 19 years of age, in-migrants the smallest. Natives have the largest proportion of old people. In-migrants have the greatest proportion of people of working ages, 20-59.

When we look at distribution by major divisions we find that all the three migrant status groups are evenly distributed in the central commercial area of Karachi. Immigrants predominate the middle residential areas-the colonies; in-migrants have large portions of their population in labour, industrial or upper residential areas, the two former areas seem to be inhabited by factory workers, etc., and the latter by high government officials. Natives predominate in the lower residential area (the old area) of Karachi and the rural areas.

Most of the best occupations are in the hands of immigrants; the second place goes to natives in such occupations. In-migrants are the 
most particular about the place of work. Fifty-four per cent of all in-migrants work in the same or adjacent chunk where they live. Immigrants seem to go out farthest for jobs. Male unemployment is the highest among natives (3.8 per cent); next come in-migrants (3.1). Female employment is rare; they form only 4.7 per cent of the total adult labour force.

In-migrant males have the lowest personal incomes; natives come next and immigrants top the list. Of the females who are in receipt of reported money income, 65 per cent earn less than Rs. 75 per month (among males 33 per cent earn less than Rs. 75 p.m.). Among female high earners, natives predominate.

In-migrant households have the smallest average size (3.4). This may be due to the fact that many in-migrants come here alone leaving their families back home. Native household size on the average is the highest. This may be due to greater incidence of joint family system among them.

Immigrants live in better houses compared to in-migrants or natives. Natives are worst off with regard to type of housing. In-migrants use rented houses more than natives or immigrants. Many in-migrants, it seems, do have houses in the upcountry but when they come to Karachi (for temporary periods), they have to use rented houses. Natives use rented houses the least. Generally, immigrant houses have more facilities (like water and electricity) compared to native or in-migrant houses.

A higher percentage of single male and female in the total of population is found among immigrants compared to in-migrants or natives. This may be due to large proportion of children among immigrants

More than 99 per cent of all marital unions in Karachi are monogamous. However, there is some evidence that polygynons marriages are found more among natives than in the migrant groups.

Nuclear family system is quite common among natives and immigrants but less so among in-migrants-due mainly to the fact that many in-migrants leave their families back home and live here as mem- 
bers of extended families or with friends. Joint families are more popular if among natives. A fairly large number of in-migrants $(73,300)$ lives as non-family types.

Immigrants' share of school-age persons (67 percent of total) is a little higher than their all-age share in the total pcpulation ( 65 per cent). Immigrants are most particular about sending children to school.

In all the three groups, males go to school more than females. In-migrant females score better (in school-going) than even native or in-migrant males.

School attendance is the highest in age group 10-14 for both sexes among all the three groups. 


\section{REFERENCES}

1. Ahmad, Nazir, Socio-Economic Survey of Rawalpindi. (Karachi: Government of Pakistan Press, 1960).

2.

Survey of Shelterless Persons in Karachi. (Karachi: Government of Pakistan Press, 1959).

3. Ali, Ahmad,

"Housing Problems of Metropolitan Karachi", A paper read at the SEATO Conference on Architecture and Structural Engineering held at Karachi in November 1963.

4. Davis, Kingsley, The Population of India and Pakistan. (Princeton: Princeton University Press, 1951).

5. Dawn, (Karachi), "50 lakh Roofless Indians," (Karachi: May 29, 1964).

6. Fazalbhoy, Zarina A. "Fertility and Attitudes to Family Planning in Karachi", in M.L. Qureshi (ed) Population Growth and Economic Development. (Karachi: Pakistan Institute of Development Economics, 1960).

7. Gist, Noel and Urban Society. (New York:Thomas Growth L.A. Halbert Co., 1954).

8. Hashmi, Sultan S.; The People of Karachi. Date from a Survey. Masihur Rahman Statistical Papers: No.2.(Karachi: Pakistan Khan and Institute of Development Economics, 1964).

Karol J. Krotki

9. Hashmi, Sultan S. Main Features of the Demographic Conditions in Pakistan. (Karachi: Central Statistical Office, 1963).

70 

India Press, 1963).

11. International Labour International Migration. (Geneva: InternaOrganization tional Labour Office, 1959).

12. Krotki, Karol J. "Industrialization: Through Large or Small Towns", A paper read at the First AllPakistan Sociological Conference, Karachi. April 1964.

13.

"The Feasibility of an Effective Population Policy for Pakistan", Pakistan Development Review, Vol. IV, No. 2, Summer 1964.

14. Ministry of Home District Census Report; Karachi. (Karachi: and Kashmir Affairs, Manager of Publication, 1961.)

15. Peterson, William Population. (New York: Macmillan Company, 1961).

16. Thompson, Warren

Population Problems. (New York: McGrawHill Book Company Inc., 1953).

17. Times of India, "Bombay Attracts Fewer Job Seekers Now", (Bombay: January 15, 1964), News report of a survey conducted by Demographic Training and Research Centre, Bombay.

18. "Middle Classes are Living Beyond Means", (Bombay: June 1, 1964). 
Social Characteristics of The People of Karachi

CHAPTER 3

Family Composition

IMTIAZUDDIN HUSAIN 


\section{CONTENTS}

Chapter 3

FAMILY COMPOSITION

\begin{tabular}{|c|c|c|c|c|}
\hline 3.0 .0 & INTRODUCTION & $\ldots$ & $\ldots$ & $\ldots$ \\
\hline 3.1 .0 & NUMBER OF FAMILI & & $\ldots$ & $\ldots$ \\
\hline 3.2 .0 & SIZE OF THE FAMILY & & $\cdots$ & $\cdots$ \\
\hline 3.3 .0 & MASCULINITY RATIO & $\ldots$ & $\ldots$ & ... \\
\hline 3.4 .0 & AGE STRUCTURE & $\ldots$ & $\ldots$ & $\cdots$ \\
\hline 3.5 .0 & \multicolumn{3}{|c|}{ CRUDE BIRTH AND DEATH RATES } & $\cdots$ \\
\hline 3.6 .0 & \multicolumn{2}{|c|}{ OCCUPATIONAL GROUPS } & $\ldots$ & ... \\
\hline 3.7.0 & INCOME & $\cdots$ & $\cdots$ & $\cdots$ \\
\hline 3.8.0 & MIGRANT STATUS & $\cdots$ & $\cdots$ & $\cdots$ \\
\hline 3.9.0 & \multicolumn{3}{|c|}{ HOUSING AND LIVING CONDITIONS } & $\cdots$ \\
\hline 3.10 .0 & MARRIED COUPLES & ... & $\cdots$ & $\cdots$ \\
\hline 3.11 .0 & SUMMARY $\quad \ldots$ & $\ldots$ & $\ldots$ & $\cdots$ \\
\hline
\end{tabular}




\section{LIST OF TABLES}

$\begin{array}{llllll}\text { Table } 3.1 & \text { Family Classification } \ldots & \ldots & \ldots & 80\end{array}$

Table 3.2 Percentage Distribution by Family Size $\ldots .81$

Table 3.3 Sub-families in Primary Families … 81

Table 3.4 Masculinity Ratio and Family Classification. 82

Table 3.5 Age Specific Masculinity Ratio (All Families $\begin{array}{lllll}\text { Combined) } & \ldots & \ldots & \ldots & 82\end{array}$

Table 3.6 Age Structure of People 0-14 by Family Classi$\begin{array}{llllll}\text { fication } & \ldots & \ldots & \ldots & \ldots & 83\end{array}$

Table 3.7 Age Structure and Family Classification 83

Table 3.8 Family Classification, CBR's and CDR's 84

Table 3.9 Family Classification and Percentage of Wo$\begin{array}{lllll}\text { men Married } & \ldots & \ldots & \ldots & 85\end{array}$

Table 3.10 Family Classification and Persons in Labour $\begin{array}{llllll}\text { Force } & \ldots & \ldots & \ldots & \ldots & 86\end{array}$

Table 3.11 Percentage of Females not in Labour Force by $\begin{array}{llll}\text { Family Classification ... } & \ldots & \ldots & 87\end{array}$

Table 3.12 Male Unemployment by Family Classification 88

Table 3.13 Family Classification and Percentage Distri$\begin{array}{llll}\text { bution by Occupational Groups } & \ldots & \ldots & 89\end{array}$

Table 3.14 Family Types and Family Income $\quad \ldots \quad 90$

Table 3.15 Number of Earners by Primary Families $\quad \ldots \quad 90$

Table 3.16 Family Classification by Migrant Status $\ldots .91$

Table 3.17 Family Classification and Type of Habitation 92

Table 3.18 Type of Marital Union by Migrant Status 93

Table 3.19 Type of Marital Union: Family Income (Percentage Distribution) ... $\quad \ldots \quad \ldots \quad \ldots \quad 93$

Table 3.20 Type of Marital Union by Occupation (Percen$\begin{array}{lllll}\text { tage Distribution). } & \ldots & \ldots & \ldots & 94\end{array}$ 


\section{Chapter 3}

\section{FAMILY COMPOSITION}

\subsubsection{INTRODUCTION}

The family is an institutionalised social group charged with the duty of population replacement. A family involves two or more persons in a series of relationships which endure beyond the death of any one member who makes it up at any given moment.

Thischapter is mainly concerned with primary families-households of an independent character having a number of persons and where the members of the household are all related to the head by blood or marriage. Primary families have been divided into three categories: i) nuclear, (mainly) consisting of husband, wife, and never-married children); $i i$ ) extended (where the nuclear family takes on one or more relatives); $i i i$ ) joint (where the nuclear family adds another sub-family mainly a married couple). Those living together but not forming a family are termed non-family type persons.

In Karachi persons who are members of nuclear families account for 60 per cent of all persons. Seventeen per cent of all persons live with extended families, 15 per cent with joint families and 8 per cent as non-family type persons.

The universal functions of the family are: $i$ ) creation of new members-a four-fold task involving reproduction, rearing of children, status ascription and socialization; ii) regulation and control of sex relations; and $i i i)$ economic organization involving control of family property and division of labour. Discussion at some length is presented about the first and the last mentioned functions in this chapter. But the family structure is dealt with in greater detail.

The functions and the structure of the family in Karachi may have been modified due to migration, industrialisation, urbanization and secularism. A few of these modifications will appear more clearly as we progress with the analysis in the chapter. 


\subsubsection{NUMBER OF FAMILIES}

There were 3,32,775 primary families in Karachi in 1959. With the total population at $1,667,150$ the average number of persons per family comes to 5.0 which is higher than that for U.S. families where it was 3.6 in 1954 [10 p. 375] (Glick's figures for 1953 put the average size of a U.S. family at 3.5$)[9$, p. 30]. Non-family type persons numbering $1,36,025$ were ignored when the above average was calculated but are considered while discussing other variables.

Nuclear families are the most common in Karachi (Table 3.1). Sixty per cent of all Karachites are members of such families. Nonfamily type persons account for 8 per cent of the total population. Extended and joint families' shares are 17 and 15 per cent respectively in the total population.

TABLE 3.1

FAMILY CLASSIFICATION

\begin{tabular}{lcc}
\hline Family classification & $\begin{array}{c}\text { Number of } \\
\text { persons }\end{array}$ & Percentage \\
\hline All classifications & $18,03,175$ & 100 \\
Nuclear & $10,81,800$ & 60 \\
Extended & $3,13,250$ & 17 \\
Joint & $2,72,100$ & 15 \\
Non-family type & $1,36,025$ & 8 \\
\hline & & Source: $[12$, Table 6.02].
\end{tabular}

Two possible reasons for a large number of persons being members of the nuclear families are: $i$ ) limited housing space for accommodating additional relatives; ii) desire for independent living, i.e., without the encumbrance of in-laws, etc. The first-mentioned reason will ba discussed later in a section on housing and living conditions.

\subsubsection{SIZE OF THE FAMILY}

The modal size of the primary family at Karachi is 4 (Table 3.2). As a comparison the modal size of the family in United States in 1953 was $2[9$, p. 30]. This means that families in Karachi are larger than 
their American counterparts. Here about 29 per cent of all families have three or less than three persons each whereas about 58 per cent of all American families come under such a category [9, p. 30].

TABLE 3.2

PERCENTAGE DISTRIBUTION BY FAMILY SIZE

\begin{tabular}{lrc} 
Family size & $\begin{array}{c}\text { Number of } \\
\text { primary } \\
\text { families }\end{array}$ & Percentage \\
\hline All sizes & $3,32,775$ & 100.0 \\
3 persons & 39,350 & 11.8 \\
2 persons & 56,500 & 17.0 \\
4 persons & 60,550 & 18.2 \\
5 persons & 56,275 & 17.0 \\
6 persons & 43,925 & 13.2 \\
7 persons & 31,775 & 9.5 \\
Over 7 persons & 44,400 & 13.3 \\
\hline
\end{tabular}

Although the modal size of the primary family is 4 and may thus look quite, large there seems to be very little tendency in this city among primary families to have sub-families. (Sub-family is defined as a married couple or a parent with never-married children related to the head or spouse of the head of primary family and sharing economic and living arrangements). Eighty-nine per cent of all primary families have no sub-families and only 10 per cent have one sub-family each (Table 3.3). The system of sharing expenses is not common here. One either lives independently or as a guest until such a time as one's individual or family income becomes high enough to demand a separate household.

TABLE 3.3

SUB-FAMILIES IN PRIMARY FAMILIES

\begin{tabular}{|c|c|c|}
\hline $\begin{array}{l}\text { Number of primary families } \\
\text { with sub-family }\end{array}$ & $\begin{array}{c}\text { Number of } \\
\text { sub-families } \\
\text { in each primary } \\
\text { family }\end{array}$ & Percentage \\
\hline $\begin{array}{l}3,32,775 \\
2,96,075 \\
32,225 \\
4,475\end{array}$ & $\begin{array}{l}\text { None } \\
1 \\
2 \text { or more }\end{array}$ & $\begin{array}{r}100 \\
89 \\
10 \\
1\end{array}$ \\
\hline
\end{tabular}




\subsubsection{MASCULINITY RATIO}

The masculinity ratio for all types of families combined comes to 124 (Table 3.4). Separate masculinity ratios for nuclear, extended and joint families are not significantly different (range 109-111), but nonfamily types have a ratio of 945 , which means that very few women in Karachi live away from their primary families. Those who do so account for less than 2 per cent of all females in Karachi (Table 3.4).

The reasons for females not living as non-family type persons may be found in the strong family ties here and a traditional approach to female education/work.

TABLE 3.4

\section{MASCULINITY RATIO AND FAMILY CLASSIFICATION}

\begin{tabular}{lcccc}
\hline \multicolumn{1}{c}{ Type of family } & $\begin{array}{c}\text { Number of } \\
\text { males }\end{array}$ & $\begin{array}{c}\text { Number of } \\
\text { females }\end{array}$ & $\begin{array}{c}\text { Masculiniy } \\
\text { ratio }\end{array}$ \\
\hline All types & $9,99,250$ & & $8,03,925$ & 124 \\
Nuclear & $5,68,775$ & & $5,13,025$ & 110 \\
Extended & $1,65,275$ & & $1,47,975$ & 111 \\
Joint & $1,42,225$ & & $1,29,875$ & 109 \\
Non-family type & $1,22,975$ & & 13,050 & 945 \\
\hline
\end{tabular}

If we look at age-specific masculinity ratio (Table 3.5) for all types of families, we find that the ratio is low for under 15's but increases and remains fairly high upto age 49 (due to male immigration and inmigration), then it declines and comes down to 108 for ages 65 and over. It is very low at ages above 65 possibly because male in-migration stops and also because higher male death rates prevail at advanced ages.

TABLE 3.5

AGE SPECIFIC MASCULINITY RATIO (ALL FAMILIES

\begin{tabular}{lc}
\hline Age group & $\begin{array}{c}\text { Masculinity } \\
\text { ratio }\end{array}$ \\
\hline All groups & 124 \\
Under 15 & 107 \\
$15-19$ & 125 \\
$20-24$ & 135 \\
$25-29$ & 134 \\
$30-34$ & 157 \\
$35-39$ & 156 \\
$40-44$ & 151 \\
$45-49$ & 150 \\
$50-54$ & 126 \\
$55-59$ & 146 \\
$60-64$ & 127 \\
65 and over & 08 \\
\hline & Soltre: [12, Table 6.01].
\end{tabular}


In the extended families, females out-number males from age 50 onwards [12, p. 254], and among non-family type persons from age 60 onwards [12, p. 254].

\subsubsection{AGE STRUCTURE}

In the overall population, as we saw in Table 3.1, persons of all ages belonging to nuclear families account for 60 per cent of all persons, in Karachi. But when we look at ages under 15 only, we find that 71 per cent of such people are from nuclear families. Nuclear families, then, have more children than their total strength would allow one to expect.

TABLE 3.6

\section{AGE STRUCTURE OF PEOPLE 0-14 BY FAMILY CLASSIFICATION}

\begin{tabular}{lcc}
\hline Family classification & Number of & Percentage \\
\hline All classification & $7,37,825$ & 100 \\
Nuclear & $5,23,025$ & 71 \\
Extended & $1,16,075$ & 16 \\
Joint & 93,800 & 13 \\
Non-family type & 4,925 & negligible \\
\hline
\end{tabular}

When we look at Table 3.7 below, we find that among non-family type persons children $0-14$ have a very small percentage of the total. Males $0-14$ of age account for 3 per cent of the total males among such persons. Among females of non-family type persons, children 0-14 of age account for 13 per cent of the total number of females. This is a rather high percentage compared with the male percentage of 3 for children 0-14 among non-family types.

TABLE 3.7

AGE STRUCTURE AND FAMILY CLASSIFICATION

\begin{tabular}{|c|c|c|c|c|c|c|c|c|c|c|}
\hline \multirow{3}{*}{ All group } & \multicolumn{10}{|c|}{ FAMILY CLASSIFICATION } \\
\hline & \multicolumn{2}{|c|}{$\begin{array}{c}\text { All } \\
\text { classifica- } \\
\text { tions }\end{array}$} & \multicolumn{2}{|c|}{ Nuclear } & \multicolumn{2}{|c|}{ Extended } & \multicolumn{2}{|c|}{ Joint } & \multicolumn{2}{|c|}{ Non family } \\
\hline & $\mathrm{m}$ & f & $\mathrm{m}$ & f & $\mathrm{m}$ & f & $\mathrm{m}$ & $\mathrm{f}$ & $\mathrm{m}$ & f \\
\hline $\begin{array}{l}\text { All groups } \\
0-14 \\
15-49 \\
50-64 \\
65 \text { and over }\end{array}$ & $\begin{array}{r}100 \\
38 \\
53 \\
7 \\
2\end{array}$ & $\begin{array}{r}100 \\
44 \\
47 \\
7 \\
2\end{array}$ & $\begin{array}{r}100 \\
47 \\
45 \\
7 \\
1\end{array}$ & $\begin{array}{r}100 \\
49 \\
47 \\
4 \\
\end{array}$ & $\begin{array}{r}100 \\
36 \\
55 \\
6 \\
3\end{array}$ & $\begin{array}{r}100 \\
38 \\
45 \\
11 \\
6\end{array}$ & $\begin{array}{r}100 \\
34 \\
52 \\
10 \\
4\end{array}$ & $\begin{array}{r}100 \\
35 \\
50 \\
12 \\
3\end{array}$ & $\begin{array}{r}100 \\
3 \\
91 \\
5 \\
1\end{array}$ & $\begin{array}{r}100 \\
13 \\
44 \\
25 \\
17\end{array}$ \\
\hline
\end{tabular}


A possible reason for a large percentage of female children living as non-family types is that they are orphans or illegitimates and therefore are forced to be on their own from such an early age. Also, among non-family type persons the percentage of females 50 and over is very high compared to other family types. These perhaps are divorced or widowed women.

When we look at extended and joint family columns, we find that these two types of families have greater percentages of old people of both sexes compared with nuclear families. Extended and joint families have a smaller percentage of children than nuclear families. The average nuclear family has more children of both sexes and fewer old people than its joint or extended counterpart. An average extended or joint family has more people in the 15-49 age group than nuclear family types.

A limitation of the comparison undertaken in this subsection should be noted. Due to differences in the definitions of family types, the basic premises which underlie this comparison are not the same. For example, a nuclear family by definition consists of parent(s) and child/children only and therefore tends to have higher proportion of children than other types of families which are not closed to other relatives and families of relatives.

\subsubsection{CRUDE BIRTH AND DEATH RATES}

Crude birth rates are the highest among nuclear families being 54 per thousand. The CBR's for extended and joint families are 43 and 44 per thousand respectively (Table 3.8 ).

TABLE 3.8

FAMILY CLASSIFICATION: CBR's AND CDR's

\begin{tabular}{lcc}
\hline Family classification & CBR & CDR \\
\hline All types combined & 47 & 11 \\
Nuclear & 54 & $*$ \\
Extended & 43 & $*$ \\
Joint & 44 & $*$ \\
Non-family & & \\
\hline denotes figures unavailable. & & Source: $[12$, Table 2.03].
\end{tabular}


Compared with Karachi's CBR of 47 per thousand (for all types of families) the CBR for Pakistan, as derived from PGE estimates of 1962 , is 44 per thousand $[11$, p. $101 ; 13$, p. 289]. Karachi's birth rate then, is higher than the all-Pakistan rate. Karachi's birth rate for all types of families combined is also higher than the one got by estimating on the basis of age spacific birth rates got from cross sectional surveys and longitudinal registration of the Population Growth Estimation (PGE) project (45.7). But Karachi's birth rates for all types of families combined are, however, lower than the one estimated by Krotki for East Pakistan (53.60 per thousand) and West Pakistan (47-54) per thousand [13. p. 447].

For the sake of comparison, we have selected the birth rates of Singapore and Hong Kong. These two urban areas have population in the above one million class consisting of a large number of recent migrants. In 1959 Singapore had a crude birth rate of 40 per thousand and Hong Kong 35 per thousand. Both these areas, then, have lower CBR than Karachi's [16, 477].

TABLE 3.9

FAMILY CLASSIFICATION AND PERCENTAGE OF WOMEN MARRIED

\begin{tabular}{lccc} 
Family classification & $\begin{array}{c}\text { Percentage of } \\
\text { persons in } \\
\text { each type }\end{array}$ & $\begin{array}{c}\text { Percentage of } \\
\text { women } \\
15-49\end{array}$ & $\begin{array}{c}\text { Percentage of } \\
\text { married women } \\
15-49\end{array}$ \\
\hline All classifications & 100 & 100 & 100 \\
Nuclear & 60 & 64 & 66 \\
Extended & 17 & 17 & 17 \\
Joint & 15 & 17 & 17 \\
Non-family & 8 & 2 & negligible \\
\hline- & & \multicolumn{2}{c}{ Source: $[12$, Table 2.03]. }
\end{tabular}

The crude birth rates among nuclear families are the highest because, to start with, there are more females of reproductive ages (i.e., between 15-49) among such families. This is shown in Table 3.9 above. Persons of all ages belonging to nuclear families account for 60 per cent of the Karachi's total population, but when we consider females aged 
15-49 only, nuclear families have 64 per cent of all females in 15-49 age groups. The percentage of married women aged 15-49 also goes higher up among nuclear families.

An average nuclear family, thus, has more women of childbearing age as compared to other families. (The birth rate among nuclear families is high due possibly to these factors also: $i$ ) privacy: which affords more chances for husband-wife sexual contact; ii) lower socioeconomic condition which are generally associated with high fertility (this point will be elaborated later in a section on income and housing); iii) traditional outlook.

Crude death rates by types of families separately are not available. But when we compare Karachi's death rate with those of Hong Kong and Singapore, we conclude that Karachi's death rate is higher than that for these two places. Hong Kong's death rate is 6.8 $[16$, p. 525] and Singapore's $6.5[16,525]$.

\subsubsection{OCCUPATIONAL GROUPS}

In Table 3.10 below, we find that 32 per cent of all persons in Karachi are in the labour force. The percentage of persons in the labour force among nuclear families is the lowest, being 26 .

TABLE 3.10

\begin{tabular}{lccc}
\multicolumn{4}{c}{ FAMILY CLASSIFICATION AND PERSONS IN } \\
LABOUR FORCE \\
Family classification & $\begin{array}{c}\text { Number in } \\
\text { labour } \\
\text { force }\end{array}$ & $\begin{array}{c}\text { Total } \\
\text { number of } \\
\text { persons }\end{array}$ & $\begin{array}{c}\text { Percentage } \\
\text { in labour } \\
\text { force }\end{array}$ \\
\hline All classifications & $5,73,900$ & $18,03,175$ & 32 \\
Nuclear & $2,78,850$ & $10,81,800$ & 26 \\
Extended & 94,550 & $3,13,250$ & 30 \\
Joint & 80,725 & $2,72,100$ & 30 \\
Non-family & $1,19,775$ & $1,36,025$ & 88 \\
\hline-1 & & Source: $[12$, Table 6.03].
\end{tabular}

In Pakistan as a whole, slightly higher percentage prevails: 32.6 per cent of the country's total population is in labour force [15, Table IV.2, 
p. 93]. The slight difference may be due to greater incidence of child labour in other parts of the country. It may also be due to a new minimum labour age limit. Seventy-four per cent of all persons among nuclear families are not in the labour force. This high percentage of "unproductive" people can be attributed to a larger percentage of children 0-14 among nuclear families as compared to other types of families (see, Table 3.7).

Among non-family type persons, workers account for 88 per cent of the total non-family population. This is mainly due to the fact that 96 par cent of the males among non-family types are of working age (15-64) (see, Table 3.7).

This is made clearer when we look at Table 3.10: the percentage of persons who are in the labour force among non-family types is actually larger than either extended or joint families.

When we look at females separately we find that among the nuclear and joint families 98 per cent of all females are not in the labour force. But there are more female workers among non-family types where only 27 per cent of the females are not working (Table 3.11).

TABLE 3.11

PERCENTAGE OF FEMALES NOT IN LABOUR FORCE BY FAMILY CLASSIFICATION

\begin{tabular}{lccc}
\hline Family type & $\begin{array}{c}\text { Total } \\
\text { females }\end{array}$ & $\begin{array}{c}\text { Females } \\
\text { not in } \\
\text { labour force }\end{array}$ & Percentage \\
\hline All types & $8,03,925$ & $7,92,400$ & 97 \\
Nuclear & $5,13,025$ & $5,10,875$ & 98 \\
Extended & $1,47,975$ & $1,43,700$ & 97 \\
Joint & $1,29,875$ & $1,27,375$ & 98 \\
Non-family & 13,050 & 9,450 & 73 \\
\hline-2 & & Source: [12, Table 6.03].
\end{tabular}

One thing is clear from the above table: whatever the type of the primary family, the same strict control on female labour is prevalent 
all through. There seems to be some relaxation of the above rule among non-family types but even here there is not much leniency. The leniency found among non-family types is due mainly to lack of family control. Unemployment is the highest among joint families and the lowest among nuclear families. High unemployment among extended and joint families can be explained thus.

TABLE 3.12

MALE UNEMPLOYMENT BY FAMILY CLASSIFICATION

\begin{tabular}{|c|c|c|c|}
\hline Type of family & $\begin{array}{l}\text { Working } \\
\text { age persons } \\
15-64\end{array}$ & $\begin{array}{c}\text { Number } \\
\text { unemployed }\end{array}$ & Percentage \\
\hline All types & $5,98,825$ & 18,925 & 3.2 \\
\hline Nuclear & $2,91,750$ & 7,000 & 2.4 \\
\hline Extended & $1,00,900$ & 4,200 & 4.2 \\
\hline Joint & 87,925 & 4,675 & 5.3 \\
\hline Non-family & $1,18,250$ & 3,075 & 2.6 \\
\hline
\end{tabular}

Persons living with extended or joint families don't try hard for employment as their parents or other close relatives continue to give them financial and moral support even if they remain unemployed for a long period.

But the other side of the picture may also be true: when a person or persons of working age are unemployed they have to depend on relatives and so don't move out and form nuclear families as in most cases the establishment of a nuclear family home is very hard. They often do so when they are financially well-off.

Other possible reasons for high unemployment among persons balonging to extended and joint families may be their lack of training or advanced age (a young unemployed person normally has better chances of employment than an old person).

The U.S. unemployment rate for 1959 (5.5 per cent) [14] is higher than the all-family combined rate for Karachi. But the Karachi figures 
may be low because people here seem to be shy in telling about their unemployment problem. Besides, extended and joint family systems perhaps provide social security for the unemployed men living with such families. An unemployed person may receive support from a brother, uncle or parent, while also working at odd jobs or seeking better employment.

Persons belonging to nuclear and extended families get a bigger share of the best jobs than their mere number in the total labour force would lead one to expect. In Table 3.13 we find that persons belonging to nuclear families account for 49 per cent of the total labour force at Karachi, but they get 51 par cent of all the professional and technical jobs and 57 per cent of all the administrative and managerial posts. Those balonging to extended families form 16 per cent of the total labour force but get 19 per cent of professional and 17 per cent of administrative managerial job3. Non-family type persons get the worst. We have defined bast and worst in terms of salary, prestige and other benefits accruing from such jobs.

TABLE 3.13

FAMILY CLASSIFICATION AND PERCENTAGE DISTRIBUTION BY OCCUPATIONAL GROUPS

\begin{tabular}{lccc} 
Type of family & $\begin{array}{c}\text { Percentage in } \\
\text { total labour } \\
\text { force }\end{array}$ & $\begin{array}{c}\text { Percentage in } \\
\text { professional } \\
\text { jobs }\end{array}$ & $\begin{array}{c}\text { Percentage in } \\
\text { administrative } \\
\text { jobs }\end{array}$ \\
\hline All types & 100 & 100 & 100 \\
Nuclear & 49 & 51 & 57 \\
Extended & 16 & 19 & 17 \\
Joint & 14 & 13 & 15 \\
Non-family & 21 & 17 & 11 \\
\hline & & & Source: $[12$, Table 6.03].
\end{tabular}

\subsubsection{INCOME}

Referring back to Table 3.1, we see that persons belonging to nuclear families account for 60 per cent of all persons at Karachi; but when we select only those persons whose family income is Rs. 300 -and-above, 
we find that they are 46 per cent of such persons (Table 3.14). Similarly, persons belonging to extended families account for 17 per cent of the total population; but looking only at persons whose family income is Rs. 300-and-above, we find that among such persons extended families account for 21 per cent and are financially better off compared to nuclear families. Applying similar logic, joint families are also better off compared to nuclear families.

The reason for nuclear families having the lowest incomes may be found in the fact that such families have a larger proportion of children and also possibly bəcause nuclear families have in most cases one earner while extended or joint families have more than one earner. Seventy-three per cent of all primary families have no earner (Table 3.15). Two earners are found among 18 per cent of families.

TABLE 3.14

\section{FAMILY TYPES AND FAMILY INCOME}

\begin{tabular}{|c|c|c|c|c|}
\hline \multirow{2}{*}{ Type of family } & \multicolumn{2}{|c|}{ All incomes } & \multicolumn{2}{|c|}{$\begin{array}{c}\text { Family incomes above } \\
\text { Rs. } 300\end{array}$} \\
\hline & Number & $\%$ & Number & $\%$ \\
\hline $\begin{array}{l}\text { All types } \\
\text { Nuclear } \\
\text { Extended } \\
\text { Joint } \\
\text { Non-family }\end{array}$ & $\begin{array}{r}18,03,175 \\
10,81,800 \\
3,13,250 \\
2,72,100 \\
1,36,025\end{array}$ & $\begin{array}{r}100.0 \\
60.0 \\
17.4 \\
15.1 \\
7.5\end{array}$ & $\begin{array}{r}3,09,525 \\
1,42,400 \\
63,525 \\
79,625 \\
23,975\end{array}$ & $\begin{array}{r}100.0 \\
46.0 \\
20.5 \\
25.8 \\
7.7\end{array}$ \\
\hline
\end{tabular}

TABLE 3.15

NUMBER OF EARNERS BY PRIMARY FAMILIES

\begin{tabular}{lrr} 
Number of earners in primary families & $\begin{array}{c}\text { Number of } \\
\text { primary } \\
\text { families }\end{array}$ & Percentage \\
\hline All & $3,32,775$ & 100.0 \\
None & 7,650 & 2.3 \\
2 & $2,42,350$ & 72.9 \\
3 & 60,550 & 18.2 \\
4 & 17,125 & 5.1 \\
5 and more & 3,775 & 1.5 \\
\hline
\end{tabular}




\subsubsection{MIGRANT STATUS}

In the total population of Karachi, the share (in terms of percentage) of natives, in-migrants and immigrants is 17,18 and 65 respectively. Keeping these percentages for all families in mind, we find from Table 3.18 that immigrants are more nuclear family-minded than other groups. Nuclear families among in-migrants groups are less common. This is possibly because in-migrant males leave behind their families and come to Karachi alone for jobs.

In-migrants' percentage in non-family types is very high (54.1). This proves the statement made in the previous paragraph. Natives are very few among non-family types but it seems that joint family system is more common among natives compared to other migrant groups. Natives' share in the overall Karachi population is 17 per cent but in the total joint family population, it is 24 per cent.

TABLE 3.16

FAMILY CLASSIFICATION BY MIGRANT STATUS

\begin{tabular}{|c|c|c|c|c|c|c|c|c|}
\hline \multirow{2}{*}{ Migrant status } & \multicolumn{2}{|c|}{ Nuclear } & \multicolumn{2}{|c|}{ Extended } & \multicolumn{2}{|l|}{ Joint } & \multicolumn{2}{|c|}{$\begin{array}{c}\text { Non-family } \\
\text { type }\end{array}$} \\
\hline & Number & $\%$ & N umber & $\%$ & Number & $\%$ & Number & $\%$ \\
\hline All status & $10,31,800$ & 100 & $3,13,250$ & 100 & $2,72,100$ & 100 & $1,36,025$ & 100 \\
\hline Natives & $1,82,450$ & 17 & 46,375 & 15 & 63,975 & 24 & 7,325 & 5 \\
\hline In-migrants & $1,52,375$ & 14 & 56,900 & 18 & 33,825 & 12 & 73,300 & 54 \\
\hline Immigrants & $7,64,250$ & 69 & $2,09,975$ & 67 & $1,74,300$ & 64 & 43,575 & 32 \\
\hline No Information & 725 & - & - & - & - & - & 11,825 & 9 \\
\hline
\end{tabular}

\subsubsection{HOUSING AND LIVING CONDITIONS}

Table 3.19 shows the number and percentages of families in pucca houses, semi-pucca houses and juggis. Looking at extended and joint family columns, we find very little difference in their habitat-31 per cent live in juggis, about 20 per cent in semi-pucca houses. When we compare these two types of families with nuclear families and nonfamily type persons, we observe that with regard to housing, extended 
and joint family types live better than others. A reason for this is perhaps the fact that the family income of an average extended or joint family is higher than the nuclear family (see section on income]. Many nuclear families then, have to live in juggis, etc., because they cannot afford better accommodation.

Another reason for nuclear families insisting on living in juggis (or semi-pucca structures, for that matter) may be found in the values of some people who are members of such families. They do own pucca houses or can afford to live in such houses but do not. This have been observed by the researcher in a number of cases but no proper study of such a trend seems to have been done at Karachi.

Non-family types are also badly hit with regard to housing. But ever? among them there is a group well-housed and another group of almost equal numbers poorly housed. The better-housed perhaps consists of military or civil officers, company managers, etc., on duty here who may have families in the upcountry but are duty-bound to live as nonfamily types. The poorly housed non-family types are in-migrants and immigrants who come here for jobs in factories and docks.

Combining all the persons of different types of families living in juggis and other undesirable clustres, we get $6,40,000$ people living in such modes of habitation. This corresponds well with Ali's estimate of 6,50,000 persons (or 1,30,000 families) [1] who are living in juggis and undesirable densities in Karachi. The slight difference in the two figures may be due to difference in the timing of data collection-our figures are based on 1959 survey while Ali's estimates were worked out in 1963.

TABLE $3 \cdot 17$

FAMILY CLASSIFICATION AND TYPE OF HABITATION

\begin{tabular}{|c|c|c|c|c|c|c|c|c|}
\hline \multirow{2}{*}{ Type of habitation } & \multicolumn{2}{|l|}{ Nuclear } & \multicolumn{2}{|c|}{ Extended } & \multicolumn{2}{|l|}{ Joint } & \multicolumn{2}{|c|}{ Non-family } \\
\hline & Number & $\%$ & Number & $\%$ & Number & $\%$ & Number & $\%$ \\
\hline $\begin{array}{l}\text { All types } \\
\text { Pucca } \\
\text { Semi-pucca } \\
\text { Juggi } \\
\text { Others }\end{array}$ & $\begin{array}{r}1,081,800 \\
463,200 \\
216,275 \\
400,950 \\
1,375\end{array}$ & $\begin{array}{r}100 \\
43 \\
20 \\
37\end{array}$ & $\begin{array}{r}313,250 \\
152,475 \\
62,400 \\
97,875 \\
500\end{array}$ & $\begin{array}{r}100 \\
49 \\
20 \\
31 \\
-\end{array}$ & $\begin{array}{r}272,100 \\
134,775 \\
52,925 \\
83,600 \\
800\end{array}$ & $\begin{array}{r}100 \\
50 \\
19 \\
31 \\
\end{array}$ & $\begin{array}{r}136,025 \\
55,675 \\
24,475 \\
54,525 \\
1,350\end{array}$ & $\begin{array}{r}100 \\
41 \\
18 \\
40 \\
1\end{array}$ \\
\hline
\end{tabular}

Source : $[12$, Table 6.06]. 


\subsubsection{MARRIED COUPLES}

In this section our aim is to find the extent of polygamy marriages in Karachi. Table 3.20 shows that monogamy is the most common type of union-99.2 per cent of all couple are monogamous. But we must be prepared to deduct one or two percentage points from the monogamous figures because some monogamous couples hide this fact on the grounds that the public at large views polygamy with cynicism.

Polygamy seems to be more common among natives.

When we look at polygamy marriages by occupations, we find that farmers and professionals are most polygamy-minded [Table 6.32]. Looking at polygamy by income (Table 3.21 ) we find that middle income groups, i.e., (Rs. 300-999) are the most polygamous.

TABLE $3 \cdot 18$

TYPE OF MARITAL UNION BY MIGRANT STATUS

\begin{tabular}{|c|c|c|c|c|}
\hline \multirow{2}{*}{ Migrant status } & \multicolumn{2}{|c|}{ Monogamous couples } & \multicolumn{2}{|c|}{ Polygamous couples } \\
\hline & Number & $\%$ & Number & $\%$ \\
\hline All status & 318,625 & 99.2 & 2,450 & 0.8 \\
\hline Natives & 55,150 & 98.3 & 975 & 1.7 \\
\hline In-migrants & 50,775 & 99.3 & 375 & 0.7 \\
\hline Immigrants & 212,525 & 99.5 & 1,100 & 0.5 \\
\hline
\end{tabular}

TABLE 3.19

TYPE OF MARITAL UNION: FAMILY INCOME (PERCENTAGE DISTRIBUTION)

\begin{tabular}{lcc}
\hline Family income & Monogamous & Polygamous \\
\hline Rs. $1-149$ & 99.4 & 0.6 \\
Rs. $150-299$ & 99.2 & 0.8 \\
Rs. $300-999$ & 98.9 & 1.1 \\
Rs. 1000 -and-over & 99.2 & 0.8 \\
\hline
\end{tabular}

Sorrce: [12, Table 6.81]. 
TABLE $3 \cdot 20$

TYPE OF MARITAL UNION BY OCCUPATION (PERCENTAGE DISTRIBUTION)

\begin{tabular}{lcc}
\hline Occupations & Monogamous & Polygamous \\
\hline Professionals & 97.7 & 2.3 \\
Administrators and managers & 98.8 & 1.2 \\
Clerical workers & 99.5 & 0.5 \\
Sales workers & 99.4 & 0.6 \\
Farmers, fishermen & 96.8 & 3.2 \\
Drivers and postmen & 99.5 & 0.5 \\
Skilled labour & 99.3 & 0.7 \\
Unskilled labour & 99.4 & 0.6 \\
Servants, etc. & 99.4 & 0.6 \\
\hline 3.11.0 SUMMARY & & Source: $[12$, Table 6.82].
\end{tabular}

There are $3,32,775$ primary families in Karachi with a total population of $16,67,150$. (The average number of persons per primary family comes to 5.0). Besides these, there are 1,36,025 non-family type persons here.

Nuclear families are the most common; 60 per cent of the total population belong to such families. Seventeen per cent belongs to extended, 15 per cent to joint, and 8 per cent of the total to the nonfamily types.

The modal size of the primary family at Karachi is 4 . The size of the family is generally large and only about 29 per cent of all families have three or less than three persons each.

The masculinity ratio in all primary families varies between 109-111 but non-family types are overwhelmingly masculine (ratio: 945 ) which proves that very few ( 2 per cent of all women) women live away from primary families. 
An average nuclear family has more children aged 0-14 compared to an average extended or joint family. Old persons (those above 65) are found more in an average extended or joint family rather than in nuclear. Ninety-one per cent of all non-family males are aged 15-49. The proportion of old females is the highest in non-family types.

Crude birth rate is the highest among nuclear families (58). This is mainly because nuclear families have the highest proportion of females in reproductive ages. The crude death rate for all families combined is 11 per thousand.

Among nuclear families only 26 per cent are in the labour force compared to 30 each for extended and joint families. The percentage is low in case of nuclear families mainly because the proportion of children 0-14 among nuclear families is higher than other types of families. Eighty-eight per cent of all non-family types are in labour force. Strict control, however, is applied on female work irrespective of the type of primary family. Some relaxation with respect to females taking up jobs is found among non-family types.

Unemployment is the highest in joint families ( 5.3 per cent) followed by extended families ( 4.2 per cent). It is the lowest in nuclear families (2.4). The high unemployment rate among extended or joint families can be explained thus: persons can afford to remain unemployed longer among such families because they continue to get support from other earning members, during the period of unemployment.

It seems that nuclear and extended families get a better share of the professional and administrative jobs than their percentage in the overall labour force would lead one to expect. Non-family types are most unlucky with regard to the above-mentioned jobs.

The family income among extended and joint families is the highest. This is largely bzcause such families have more earners. The family income among nuclear families is low mainly because of high birth rate and consequently a larger proportion of dependents.

About 73 per cent of all primary families have one earner only.

The proportion of single persons of both sexes is the highest among nuclear families (mainly due to a greater proportion of children) and 
the proportion of married parsons of both sexes is the highest amongst joint families (this is as it should be, because a joint family in most cases has 2 married couples).

Among primary families, an average extended family has more widowed parsons compared to other types of families. Non-family type females have the highest proportion of widows.

Considering migrant status and family composition, we find that generally, nuclear families are a bit more common among immigrants; Most in-migrants either live with the family of their relatives (extended families) or with friends, etc. (non-family types). Joint families are more common among natives.

An average extended or joint family shows the greatest tendency to live in pucca houses compared to other types. A greater proportion of non-family types and nuclear families are living in juggis compared to other types. Thus, with regard to housing, extended and joint families live better which is a result of better incomes.

There is very little polygamy in Karachi $(0.8$ per cent of all married couples are polygamous). Although the number of polygynous couples is very small to justify accurate trends and results we can say on available evidence that such marriages seem to be slightly more commona mongnatives compared to other migrants. Again, polygynous marriages seem to be more common among middle income groups (Rs. 300-999) than among other income groups. If we look at marriages by occupation, we find that farmers and professionals are relatively more polygamous than others. 


\section{REFERENCES}

1. Ali, Ahmed

"Housing Problems of Metropolitan

Karachi". A paper read at the SEATO Conference of Architecture and Structural Engineering held at Karachi during November 1963.

2. Blake, Judith Family Structure in Jamaica. (Glencoe :Free Press, 1961).

3. Chilman, Catherine, "The Crisis and Challenge of Low Income S. Families in the 1960's: Implications for Parent Education", Journal of Marriage and the Family, Vol. 26, No. 1, February 1964.

4. Cormack, Margaret She Who Rides a Peacock. (Bombay: Asia L. Publishing House, 1961).

5. Desai, A.R. Rural Sociology in India. (Bombay: Indian Society of Agricultural Economics, 1961).

6. Duncan, Otis Social Characteristics of Urban and Rural Dudley and Communities, 1950. (New York: John Willey Albert J. Reiss \& Sons, Inc., 1956)

7. Freedman, Ronald and Pascal K. Whelpton

Family Planning, Sterility and Population Growth. (New York: McGraw-Hill Book Company Inc., 1959).

8. Freedman, Ronald Principles of Sociology. (New York: Henry, et al. Holt and Co., 1952).

9. Glick, Paul C. American Families. (New York: John Willey \& Sons, Inc., 1957).

10. Green, Arnold W. Sociology. (New York: McGraw-Hill Book Company Inc., 1959).

11. Hashmi, Sultan S. Main Features of the Demographic Conditions in Pakistan. (Karachi: Central Statistical Office, 1963). 
12. Hashmi, Sultan S. The People of Karachi: Data from a Survey. et al. (Karachi : Pakistan Institute of Development Economics).

13. Krotki, Karol J. "Population Size, Growth and Distribution: First Release from the 1961 Census of Pakistan", Pakistan Development Review, Vol. III, No. 2, Summer 1963.

14. Ross, Arthur M. Unemployment and the American Economy. (New York: John Wiley, 1964).

15. Pakistan, Office of Population Census of Pakistan 1961, District the Census Commis- Census Report: Karachi. (Karachi: Manager sioner. of Publications).

16. United Nations Demographic Yearbook 1962. (New York: United Nations, 1962). 
Social Characteristics of The People of Karachi

CHAPTER 4

Housing and Living Conditions

S. A. A. B. RIZVI 
CONTENTS

ChAPTER 4

HOUSING AND LIVING CONDITIONS

105

$\begin{array}{llllll}4.1 .1 & \text { Introduction } & \ldots & \ldots & \ldots & 105\end{array}$

$\begin{array}{lllll}4.1 .2 & \text { Object of the Study } & \ldots & \ldots & 106\end{array}$

4.1.3 Basic Unit of Study $\quad$... $\quad \ldots .6106$

4.1.4 Housing and Living Condition-The Total Picture 107

4.2.0 HOUSING CONDITIONS IN MAJOR AREAS 110

$\begin{array}{llllll}4.2 .1 & \text { Households } & \ldots & \ldots & \ldots & 110\end{array}$

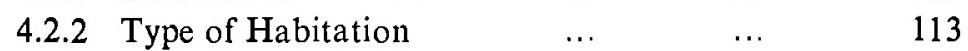

$\begin{array}{lllll}4.2 .3 & \text { Tenure of Habitation } & \ldots & \ldots & 115\end{array}$

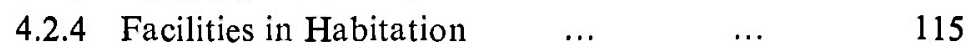

4.3.0 HOUSING CONDITIONS IN RELATION TO MIG-

$\begin{array}{lllll}\text { RANT STATUS } & \ldots & \ldots & \ldots & 115\end{array}$

$\begin{array}{llllll}\text { 4.3.1 } & \text { Households } & \ldots & \ldots & \ldots & 117\end{array}$

$\begin{array}{lllll}\text { 4.3.2 Type of Habitation } & \ldots & \ldots & 119\end{array}$

$\begin{array}{lllll}\text { 4.3.3 Tenure of Habitation } & \ldots & \ldots & 119\end{array}$

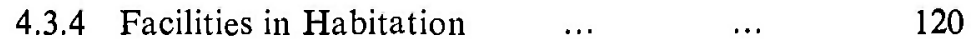

4.4.0 HOUSING CONDITIONS IN RELATION TO IN$\begin{array}{lllll}\text { COME } & \ldots & \ldots & \ldots & 120\end{array}$

$\begin{array}{llllll}4.4 .1 & \text { Households } & \ldots & \ldots & \ldots & 120\end{array}$

$\begin{array}{lllll}4.4 .2 & \text { Type of Habitation } & \ldots & \ldots & 122\end{array}$

$\begin{array}{lllll}4.4 .3 & \text { Tenure of Habitation } & \ldots & \ldots & 122\end{array}$

4.4.4 Facilities in Habitation $\quad \ldots \quad \ldots \quad \ldots \quad 122$

4.5.0 SUMMARY AND CONCLUSION $\quad \ldots \quad 123$ 


\section{LIST OF TABLES}

$\begin{array}{lllll}\text { Table } 1 & \text { Average Household Size by Major Division } & \ldots & 126\end{array}$

Table 2 Per Cent Breakdown of Households by Size for each Major Division $\quad \ldots \quad$...

Table 3 Per Cent Breakdown of Household Size Groups by Major Division $\quad \ldots \quad \ldots \quad \ldots$

Table 4 Per Cent Distribution by Type of Habitation and Major Division $\quad \ldots \quad \ldots \quad \ldots$

Table 5 Per Cent Distribution by Tenure of Habitation and Major Division $\quad \ldots \quad \ldots \quad \ldots$

Table 6 Per Cent Distribution by Facilities in the Household (Water and Electricity) and Major Division

Table 7 Per Cent Distribution of Households with Bathroom or Latrine by Major Division

Table 8 Per Cent Distribution of Population by Migrant Status and Household Size

Table 9 Per Cent Distribution of Population by Type of Habitation and Migrant Status

Table 10 Per Cent Distribution of Population by Migrant Status and Type of Habitation $\quad \ldots \quad$...

Table 11 Per Cent Distribution of Population by Tenure of Habitation and Migrant Status Group $\quad \ldots \quad 136$

Table 12 Per Cent Distribution by Type of Habitation and Tenure of Habitation $\quad \ldots \quad$...

Table 13 Per Cent Distribution of Population by Tenure of Habitation and Migrant Status

Table 14 Per Cent Distribution of Households with Water and Electricity by Migrant Status

Table 15 Per Cent Distribution of Households with Bath or Latrine by Migrant Status 
Table 16 Per Cant Distribution of Fa milies by Household Size and Family Income $\quad \ldots \quad \ldots \quad \ldots \quad 141$

Table 17 Per Cent Distribution of Occupational Groups $\begin{array}{llll}\text { by Household Size } & \ldots & \ldots & 142\end{array}$

Table 18 Average Household Size by Occupational Group 143

Table 19 Per Cent Distribution of Population by Type of Habitation and Family Income Group $\quad$.. $\quad 144$

Table 20 Per Cent Breakdown by Tenure of Habitation for $\begin{array}{llll}\text { each Family Income Group } \quad \ldots & \text {... } & 145\end{array}$

Table 21 Per Cent Breakdown of Households by Avail- ... ability of Water and Electricity for each Family Income Group $\quad \ldots \quad \ldots \quad \ldots$

Table 22 Per Cent Breakdown of Households by Availability of Bathroom and Latrine for each Family Income Group 


\section{Chapter 4 \\ HOUSING AND LIVING CONDITIONS}

\subsubsection{THE STUDY AND THE TOTAL PICTURE}

4.1.1 Introduction: As a result of contemporary political unrest, significant international migrations have occurred in certain areas of the world ${ }^{1}$. One of such movements took place in the Indo-Pakistan subcontinent, whose partition in 1947 enforced movements absolutely unparalleled in the history of the world [25, p. 110]. During this troubled period, India and Pakistan are estimated to have exchanged 14 to 15 million persons with almost equal number (about 7 million) coming in and going out $[12$, p. 62$]$.There was, however, one important aspect of this phenomenon: while people migrated both from cities and villages, they settled mostly in cities [10]. Among cities, big cities like Karachi, received the biggest impact; in fourteen years' time (1947-1961), it quadrupled its population ${ }^{2}$.

The result was obvious. The growth of services could not keep pace with the growth of consumers of those services. As would appear in the following pages, certain necessities like houses, community facilities and public utilities became seriously deficient. In short, rapid population growth gave rise to following problems in the area of urban development:

a) lack of housing and related facilities

b) congestion and overcrowding in the older central parts of the city

c) increased traffic beyond the capacity of existing roads

d) haphazard growth

e) indiscriminate mixture of land use [19, pp. 5-6].

1 E.g., West Germany (Berlin), Hungary, India, Pakistan and Hong Kong.

2 By the end of 1947, the population was estimated to be 5,00,000. In 1961, it crossed the $(2,044,044)$ million mark according to the second population census of Pakistan [23]. 
Hundreds of slum clusters appeared in cities. This is, however, not unusual under the circumstances. "... most dramatic examples of accelerated urban growth are the shanty towns" [26, p. 3]. Problems also arose because of not studying the problems in details. And of this fact, there is increasing realization among professionals: action programme to be effective must be based on an adequate knowledge of the socio-economic setting in which they are to be carried out" [5, p. 32].

4.1.2 Object of the Study: As a result of this realisation, surveys of many cities have been taken to draw up proper plans and to deepen the understanding of a given situation. A survey of Karachi was long overdue; although occasional surveys of isolated groups and areas had been conducted, they were too sporadic and of local and topical interest $[1 ; 15 ; 21 ; 17]$. The present study is based on an exhaustive survey which provides enough meat to academicians and professionals for the performance of their respective tasks [9].

This chapter purports to present and account for findings related to the housing and living condition of the people of Karachi as revealed by this survey [9] ${ }^{3}$. It is hoped that it would greatly benefit the planning and development agencies of Karachi ${ }^{4}$.

4.1.3 Basic Unit of Study: Housing has a meaning wider than has bəen taken traditionally. From family's standpoint, it comprises certain facilities besides mere shelter. It includes the relationship of individual dwellings to the surrounding areas [13, p. 557]. It constitutes the physical environment in which the society's basic unit, the family, develops [5]. In this sense, it is more than bricks and mortars. It is "a biological institution, a specialised structure, devoted to the function

${ }^{3}$ In this study, unless otherwise stated:

a) "Karachi" means the Karachi Metropolitan Area (KMA).

b) "Housing condition", "living condition" and "Housing and Living condition" have been alternatively used; they all connote the same sense.

4 The main planning agencies are: Karachi Development Authority (KDA); West Pakistan Housing and Settlement Agency (WPHSA); Karachi Municipal Corporation (KMC); Karachi Port Trust (KPT); Military Cantonment Board. 
of reproduction, nutrition and nurture" [14, pp. 446]. In this study, therefore, it is not the house but a functioning unit, a household which is of interest.

4.1.4 Housing and Living Condition-The Total Picture: The quadrupling of the population of Karachi in fifteen year's time $(5,00,000$ in 1947 to $20,00,000$ in 1961) gave rise to problems in almost every phase of its development, i.e., planning, communication and community facilities. This imbalance between the need and provision has been the basic concern of city planners.

The most noticeable lag has, however, been in the area of housing. This is displayed by a survey of shelterless persons carried out in 1959 . The survey reported $5,27,535$ persons either homeless or living on pavements or in temporary tenements in 1959 . They lived in 250 slum'clusters which were conspicuous by substandard juggies ${ }^{5}$. The living condition is well depicted by Nazir Ahmed. "They live packed like sardines, in colonies which are disease-ridden . . . a case of gross cultural regression, of dehumanization, of degradation which staggers human imagination" [2, p. 2].

The congestion of people in space which is expressed in terms of number of persons per unit area (density) indicates-though roughly the state of crowding in a city. Karachi city is becoming denser with the passage of time. In 1951 , a square mile contained 4,628 (7.2 persons per acre); in 1961 , there were 8,316 persons to a square mile ([23, p. IV-5]) i.e., 13.0 persons per acre. This was because of almost doubling of population during 1951-61.

There is, however, variation in density as between various areas of Karachi. The density varies from as low a figure as 0.49 persons per acre in certain rural dehs in the Malir valley to as high a figure as 693 persons per acre in the old town. In commercial area, the density exceeds 300 persons per acre, although in the south and south-western portion, it is around 50 due to marshy land. Notwithstanding the within-city varia-

5 About 1,50,000 i.e., 30 per cent of shelterless persons reported in 1959, have been settled in Korangi and North Karachi Townships to-date, according to information from the Karachi Development Authority. 
tion, a general tendency is noticed, viz., the gradual diminution as one moves radially outwards from the central business district. This central business unit occupies smallest proportion of area but biggest proportion of Karachi population. The same is true in all big cities, e.g., "... in American cities at least the central business district occupies a relatively small proportion of the entire area of the country" [6, p. 98].

The generalized predominant land-use map indicates the indiscriminate mixture of land uses. This has probably led people living in the central areas of the city to move out to newly developed communities in the outskirts. There too, housing units are installed more rapidly than shops, factories, schools and hospitals ${ }^{6}$. Consequently, commercial and community functions infiltrate into residential units. Planning regulations, even if they exist, do not seem to be adhered to.

The following table compares the residential areas of Karachi with those of other cities:

Comparative Statement of Residential Areas

\begin{tabular}{|c|c|c|c|}
\hline \multirow[b]{2}{*}{ Cities } & \multirow{2}{*}{$\begin{array}{l}\text { Total } \\
\text { developed } \\
\text { land per } \\
1000 \text { of } \\
\text { population } \\
\text { (acres) }\end{array}$} & \multicolumn{2}{|c|}{ RESIDENTIAL } \\
\hline & & $\begin{array}{c}\text { Percentage } \\
\text { of total } \\
\text { area }\end{array}$ & $\begin{array}{l}\text { Acres per } \\
\text { capita }\end{array}$ \\
\hline $\begin{array}{l}\text { 1. British industrial towns } \\
\text { 2. British port towns } \\
\text { 3. Madras } \\
\text { 4. Bangalore } \\
\text { 5. Korangi town (Karachi) } \\
\text { 6. Karachi (estimated) } \\
\text { 7. Karachi (existing) }\end{array}$ & $\begin{array}{l}51.4 \\
59.5 \\
12.4 \\
13.0 \\
40.7 \\
32.0 \\
16.0\end{array}$ & $\begin{array}{l}42.6 \\
35.8 \\
54.8 \\
53.8 \\
35.8 \\
60.0 \\
23.6\end{array}$ & $\begin{array}{r}21.9 \\
21.3 \\
6.8 \\
7.0 \\
14.6 \\
19.3 \\
3.8\end{array}$ \\
\hline
\end{tabular}

It is evident that the percentage of developed land and the percentage of residential areas to the total area is below that of planned cities.

The size of a typical household of Karachi is 4.4. This figure itself in isolation is not meaningful; however, when viewed in relation to the

6 As an isolated illustration, out of the 46 schools provided in the KDA's Development Scheme No. 16 (Federal B Area) none has been built, although more than half of the planned population $(1,15,000)$ has started living. Similarly, there is not a single hospital or maternity centre $[20$, p. 22]. 
fact that a household contains on an average 1.4 rooms and a room contains an average of 3.7 persons, the state of overcrowding in Karachi becomes clear. Compared in this respect to some of the surveyed cities of the Indo-Pakistan subcontinent, the condition of overcrowding appears still more acute.

In respect of the size of household, type of houses, and the amenities therein, the housing condition in the city is poor; poorer in fact than in some of the similar cities in Asia. A sizeable proportions of the people (i.e., more than half) live in poor houses. Three-fourths of the households lack altogether the essential amenities like water and electricity etc. From the standpoint of such community facilities as schools and hospitals, the backlog is equally serious. Fifty-nine per cent of children in primary age group and 31 per cent in secondary age groups attend school. There are 1.7 hospital beds per 1,000 population as against 5 per thousand, the required standard ${ }^{7}$. Water supply arrangement is poor. Per capita water consumption was hardly 2 gallons (in 1952) as against 35 gallons worked out by experts.

Population and housing trends are closely related. "... social and economic processes that affect the number and the composition of the households are topics for population study [and] ... also a part of the foundation upon which all housing analysis is built." [4, p. 710].

In case of the heterogeneous community of Karachi, it is advisable to study the housing condition by socio-economic groups. The synthetic picture conceals some of the minor problems and causes thereof; analysis by groups exposes problem in details which is needed for community planning on local levels. "Specific projects for a residential community or neighbourhood unit must be based on definite knowledge of a multitude of economic social, cultural, physical and other facts" [5, pp. 32-33].

In this study, three major groups based on geographic (land use), economic (income and occupation) and social (migrant status) criteria are identified and housing condition studied with reference to them.

7 The standard worked out by the Karachi Development Authority Karachi. 
The condition has been viewed from $a$ ) the extent to which a household is overcrowded; $b$ ) type of houses in terms of structure; $c$ ) tenure of houses; and $d$ ) facilities in a household.

\subsubsection{HOUSING CONDITION IN MAJOR DIVISIONS}

Karachi has been divided into eight major areas. The criteria of division was land use and density. These areas should ideally correspond to the natural areas, as measured by physical indexes, density and cultural "characteristics of the people who inhabit it" [28, p. 412]. Such homogeneous areas or natural areas are not typical of Karachi only. The matropolitan areas of New York, Chicago, Philadelphia, Los Angeles and San Francisco contain a great variety of natural areas, each with its characteristic sub-cultures [13, p. 414].

4.2.1 Household Size (Tables 1-3): In housing studies, reference to a group rather than an individual, should be of interest, because it is the former who inhabits a house. Houschold as a group is of interest in this study. "Household" has been defined "as a family or group of families or of persons living together and eating from the same kitchen" [16, p. 46]. A family, on the other hand, is a group with a common head. This definition of household is the same as that of the United States Cansus, the Pakistan Census and of such studies like that of C2lcutta, Mysore, Ludhyana (India), Amman (Jordon) and Tema (Ghana).

The first finding of interest is a rather low average household size (4.4) for Karachi compared to that of Karachi district (5.3) and the whole of West Pakistan (5.5). In accounting for this disparity, the following points may be remembered.

a) The 37,000 persons not accounted for in this survey [9] might belong to a group of big households so as to affect the census figure.

a) About 1,00,000 prrsons living in newly developed colonies (Korangi, Landhi, etc.) were living at the time of the 1959 survey in the city's slum clusters. After the survey small juggies households groups might have turned into big households in more spacious houses. 
c) Tendency among juggi-dwellers to report many household units so as to claim many houses in the rehabilitation schemes, a case not so frequently found in routine censuses 8 .

d) Some expected lag batween a sample and census.

Since, no population displays such a behaviour as to reduce appreciably the household size in a year or so, doubt is cast on the conduct of the survey. The survey records 53,875 single-person households; the census figure is 26,370 . The former forms 13.2 and the latter 7.2 per cent of the respective totals. This shows wide gap between figures. Perhaps soldiers in a military barrack eating in a mess were counted as one household in survey and as many households as the number of soldiers in a barrack in sample. They do show a small household size (2.6).

In the presence of this ambiguity, it is safe to take the average of the sample and census figures, i.e., 4.8. This is higher than that of Calcutta and Bombay (4.2) and lower than that of Aman (6.5) which is explainable. Calcutta and Bombay are the two most male cities in the world, [24, p. 14], the masculinity ratio being 166 and 176 respectively. They consequently contain an exceedingly high proportion (Calcutta 50 per cent) of single person households (Karachi: 13 per cent). Quite noteworthy is also the fact that the immigrant-dominated population of Karachi socially and demographically behaves like a settled population [8].

According to the census figures, persons per household and per inhabited dwelling for Karachi district work out to be 5.3 and 5.1 respectively. This is lower than 5.7 and 5.9 for Pakistan and signifies that either the people of Karachi live less crowded than the bulk of Pakistanis or the dwellings in Karachi are smaller than elsewhere.

This observation should not surprise those acquainted with living condition of big cities in the fast growing countries. However, the closeness of two figures for the metropolis and the country shows that they are both one-household-one dwelling communities. There is the

8 There are reports that, during and before the Karachi survey, more than usual claims of new ration cards were reported. 
fear that ". . . they (the two figures) under-indicate the true average as they include both the population and the number of institutional households" [11, p. 76].

Both averages are lower for Karachi than for Pakistan as a whole, perhaps due to the operation of extended and joint family system to a greater degree in Pakistan.

Significant variation is noticed as between major divisions (Table D). In typical residential areas, people live in big households, the exception being the upper residential area. The skewness of the frequency curve for those areas shows a relative preponderance of middle-sized households. Small households (average 2.6) is the typical feature of non-contiguous areas. Large households (average 5.0) is the feature of rural area.

Following explanations may be advanced of the relatively low household size in the Upper Residential Area.

a) Preponderance of nuclear families in this area.

b) Preponderance of single person households. One-fifth of all single person households of Karachi are in this area.

c) Preponderance of foreigners in this area: almost all the foreigners live in this area.

d) Preponderance of high income and elite class.

The household structure of commercial area and residential area is akin. This may be because the upper storeys of multi-storeyed buildings are residential. The rather low household size in non-contiguous area is not unusual: 61 per cent of all households are single person households. Industrial area is the third claimant of single person households ( 18 per cent). These are the in-migrants who come alone for jobs.

Two major divisions, middle residential and commercial area, constitute about 4 per cent of the Karachi area, but contain about half 
of the total households of Karachi. On the other extreme, rural area claiming three-quarters of the Karachi area contains only 4 per cent of its households. This presents the crux of the living problem.

Residential and commercial areas are the most preferred lands for living purposes. Rural area which is the biggest major division area-wise is the smallest population-wise. It contains only a few scattered villages. The dry and waste land does not attract sufficiently large population; population is, therefore, sparse.

4.2.2 Type Habitation of (Table 4): Habitation is identified in this study as a space occupied for dwelling purposes which according to the typs of structure is categorised into three: pucca, semi-pucca and juggies". Dwelling is "pucca" when it is built entirely of bricks, stones or concrete; it is "semi-pucca" when it is built partly of pucca and partly of "semi-pucca" material; and it is juggi when it is made of straw, bamboo, sacks and mats [16, p. 46-47].

A little less than half of the people of Karachi live in pucca houses (45 per cent). Of the rest, living in non-pucca houses, majority live in juggies. The state of living is further aggravated by the fact that in the slum clusters there is absence of proper roads, open spaces, water and drainage arrangements.

In respect of type of houses, commercial and non-contiguous areas appear superior to other areas; more than three-fifths of the papulation in the former and four-fifths in the latter area live in pucca houses (Table 8). Commercial area is the central business district containing multi-storeyed pucca apartments. In large cities like Karachi "business activities of the downtown attract the kind of residents who can pay adequate rents and live in high rent apartment buildings and value location with convenience of access to their place of work" [7, p. 418]. In non-contiguous areas, all structures are pucca as most of the building are government owned.

9 Besides these there are two other categories: a) "on roof tops" and b) "no regular shelter" which have been lumped up under "others"; they are insignificant. 
In industrial area, houses are poor. This indicates that labourers prefer to live in juggies and semi-pucca structures near their workplaces rather than in better houses in a distant neighbourhood ${ }^{10}$.

The fact that three-fourths of the people live in juggies in rural area should not suggest poor housing. The katcha houses which are graded juggies by definition are consistent with local needs and are the architectural creation of the peasants. Thus, such statistical materials should be substantiated with observation. Cities of Mysore State in India have been graded superior to village because of the relatively large proportion of bricks and stone houses in Banglore city but rightly with a reservation, "though more detailed investigations would be required to permit an exact comparison" [27, p. 75].

In the following table the housing condition in terms of structure of two groups of communities, the residential and functional has been generalized:

Type of Habitation by Communities

\begin{tabular}{lrrrrr} 
Communities & All & Pucca & $\begin{array}{c}\text { Semi- } \\
\text { pucca }\end{array}$ & Juggis & Others \\
\hline Residential communities & 100.0 & 33.8 & 21.7 & 44.2 & 0.2 \\
Funstional communities & 100.0 & 57.6 & 17.5 & 24.5 & 3.0 \\
\hline
\end{tabular}

Even making allowance of the generalization in the delimination of major divisions ${ }^{11}$ it appears that the non-residential or functional communities have better housing facilities than residential communities $^{12}$.

10 In a survey conducted by the Pakistan Ekistic Training Centre, Karachi, great resistance was noticed on the part of the residents of Lyari area against shifting to a new area, the North Karachi Township.

11 For the sake of keeping contiguous major divisions many groups of chunks were lumped with major divisions under which they were otherwise not qualified for inculsion.

12 Residential communities include: lower residential area, middle residential area, upper residential area, labour area, and rural area; functional communities include: commercial area, industrial area and non-contiguous area. 
4.2.3 Tenture of Habitation (Table 5): Three types of tenure have been identified in this study: $a$ ) owned, $b$ ) rented, and $c$ ) rent free. Their meaning is self-explanatory. It is found that a little more than half ( 54.3 per cent) of the people of Karachi live in owned houses, but ownership is confined mostly to poor houses (juggies). Residential communities are better than functional communities from the tenure point of view.

Tenure of Habitation by Communities

\begin{tabular}{lccccc}
\hline Communities & All & Owned & Rented & Rent free & others \\
$\begin{array}{l}\text { Residential } \\
\text { communites }\end{array}$ & 100.0 & 60.6 & 24.8 & 14.2 & 0.4 \\
$\begin{array}{l}\text { Functional } \\
\quad \text { communities }\end{array}$ & 100.00 & 46.1 & 34.3 & 18.3 & 1.3 \\
\hline
\end{tabular}

There is a tendency that in residential areas, people build juggiehouses mostly for their own living whereas in functional areas (mainly the commercial area), houses are built partly for living and partly for renting purposes.

4.2.4 Facilities of Habitation (Tables 6 and 7): From the extent of the availability of two types of facilities, i.e., water and electricity (facilities I) and bathroom and latrines (facilities II), housing condition appears poor. It is poorer in terms of facilities I than facilities II. Among major industrial, lower residential, labour rural households are much seriously deficient compared to other major divisions. It is evident that areas which are poor from the standpoint of type of structures are poor from the point of view of facilities too.

\subsubsection{HOUSING CONDITIONS IN RELATION TO MIGRANT STATUS}

Housing problem is not peculiar to Karachi alone. All the immigrant-dominated cities are confronted with this problem. Hong Kong rose six times during 1945-60. Singapore and Kuala Lumpur (Malaya) doubled during the 1950-60 decade. Amman (Jordan) trebled in twelve years' time (1948-60). Karachi (Pakistan) quadrupled in fourteen years' time $(1947-61)^{13}$.

13 The present population of these immigrant-dominated cities is: Hong Kong 29,81,000 (1960); Singapore (16,34,000 (1960); Karachi 20.44.044 (1961); Kuala Lumpur 3,16,239 (1957); Amman 1,93,450 (1960). 
Besides being of academic interest, the study of housing condition of various migrant groups is likely to provide useful data to professional practitioners and planning agencies of Karachi. It is interesting sociologically. The extent of difference is likely to give an idea about the degree of integration of some of the migrant and native traits. A hypothesis may ba examined: good housing condition of migrants compared to natives display that they are more progressive and enterprising.

Migrant status has been categorised into $a$ ) migrants and $b$ ) natives. Migrants have been categorised into $a$ ) those that have either come from up-country (in-migrants) or $b$ ) from across the borders of Pakistan (immigrants) ${ }^{14}$. Natives are the original inhabitants of Karachi, i.e., local Sindhis and Makranis, also including small community of Ismailes, Boras, Parsis and others. The relative frequency distribution of the population and households by migrant status is as follows ${ }^{51}$ :

Per Cent Distribution of Population and. Households by Migrant Status

\begin{tabular}{lcc} 
Migrant status & Population & Households \\
\hline All statuses & 100.0 & 100.0 \\
Migrants & $82.7(100.0)$ & $85.0(100.0)$ \\
$\quad$ in-migrants & $17.5(21.2)$ & $23.1(27.2)$ \\
$\quad$ immigrants & $65.1(78.2)$ & $61.9(72.8)$ \\
Natives & 16.6 & 14.9 \\
No information & 0.7 & 0.1
\end{tabular}

Like Kuala Lumpur, Hong Kong and Calcutta, Karachi is found to be predominantly migrant-occupant city. These migrants are mostly of Indian origin having arrived in the city during the post-Partition years.

\footnotetext{
14 In the survey, household heads were interviewed and reported about household members. Their offspring who were born in Karachi also shared the migrant status of the interviewee.

15 The intention of presenting this table is to keep the reader acquainted with the size of migration groups, as their housing condition is discussed.
} 
Taking all indices of housing condition, i.e., household size, type, tenure and facilities, the migrants live better than natives and from amongst migrants, immigrants live better than in-migrants.

4.3.1 Households (Table 8): Among the people of Karachi, natives claim more numerous parsons to a household than migrants. Among the latter, immigrants from India claim more numerous persons to a household than either in-migrants or immigrants from countries other than India.

Household Size by Migrant Status

\begin{tabular}{|c|c|}
\hline Migrant status & $\begin{array}{c}\text { Average } \\
\text { household size }\end{array}$ \\
\hline All statuses & 4.4 \\
\hline Migrants & 4.3 \\
\hline in-migrants & 4.6 \\
\hline immigrants : from India & 4.6 \\
\hline from other countries & 3.0 \\
\hline Natives & 5.0 \\
\hline
\end{tabular}

As has been seen in the preceding pages that natives live mostly in poor areas and as will be observed in the following pages that natives live mostly in poor structures and are mostly poorly equipped in respect of certain facilities like water, electricity, etc., it is safe to say that of all migrant groups, natives live under the most overcrowded conditions.

The frequency distribution displays a positive association of diminishing frequency of households with increasing size of households. This is what is the case in such distributions. The skewness of the curve for inmigrants and migrants from countries other than India is due to the existence of a large number of single persons in them. The similarity of the curve for Karachi and migrants displays the tendency of a migrant community. 
By taking the simultaneous account of the number of rooms and the number of persons in a household a measure of degree of crowding can be arrived at. The conventional measure is the number of persons par room, in which respect the following picture appears:

Number of Persons per Room

\begin{tabular}{lc}
\hline Average number of rooms per household & 1.4 \\
Average number of persons per household & 4.4 \\
Average number of persons per room & 3.7 \\
N.E. Megalapolis (USA) & 0.7 \\
Accra (Ghana) & 1.7 \\
Chittagong & 2.5 \\
Rawalpindi & 2.7 \\
Lahore & 2.8 \\
Dacca & 3.2 \\
Calcutta & 3.2 \\
Peshawar & 3.3 \\
Hyderabad & 4.7 \\
\hline
\end{tabular}

Source: District Census Reports.

This table displays poor living conditions in Karachi. In respect of room density the condition is poorer than other areas.

The large cities of Pakistan appear blighted in terms of overcrowding. The situation is contrary to the one found in developed areas of the United States, where they do not appear socially blighted in terms of overcrowding [7, p. 409].

In terms of per room density the housing situation can be graded as follows:

Housing Situation in Terms of per Room Density

\begin{tabular}{ccc} 
Number of persons per room & $\begin{array}{c}\text { Percentage } \\
\text { of population }\end{array}$ & Grade \\
\hline 1 and less than 1 & $\begin{array}{c}7.0 \\
\text { Ideal } \\
3 \text { \& more than } 3\end{array}$ & $\begin{array}{c}\text { Tolerable } \\
\text { Overcrowded }\end{array}$ \\
\hline
\end{tabular}


The situation is brought to more focus when it is compared with the United States where "... 1.51 or more persons per room is regarded an evidence of definite overcrowding." [4]. The situation is worse among the original inhabitants of Karachi (natives) who live mostly in Lyari Area where 60 per cent of houses contain one room only [22] and where 4 persons live in a room.

4.3.2 Type of Habitation (Tables 9 and 10): From the standpoint of the type of houses also the picture appears unsatisfactory. It is still less satisfactory in the case of natives than it is in the case of migrants. From among migrants, in-migrants live in poor houses compared to immigrants. This is consistent with what has been observed from the criteria of household size.

Many explanations can be advanced why natives live in poor houses. First is the pure economic reason; they are low-income people with a high level of consumption. They have lived in dry and low-lying areas and have not seen the light of education ${ }^{16}$. They would not sacrifice the proximity with workplaces for better housing in a distance place. On the other hand, the manner in which migrants have bettered their condition indicates that the momentum of struggle in a migrant population is faster than in a settled population.

4.3.3 Tenure of Habitation (Tables 11, 12 and 13): A little more than half of the people of Karachi live in owned houses. In this respect Karachi is poorly placed compared to other cities of Pakistan.

In respect of tenure, however, natives are better placed than migrants. Similarly among migrants, in-migrants display a little poorerownership condition than do immigrants. This, however, does not mean that the housing condition of owners judged in term of type and facilities is good. In fact the findings are that the ownership is associated with poor houses, while poor tenure (rented and rent-free) is associated with good houses (Table 11a). Taking into account the type and tenure of houses, it can be said that the ownership improves as the population moves from the temporary to settled state.

16 See for details the relevant chapter in this monograph. 
4.3.4 Facilities in Habitation (Tables 14 and 15): In respect of the availability of facilities I (water and electricity), although the overall condition in Karachi is extremely poor, the condition in native households is poorer than in migrant households. One out of eight native households and one out of six immigrant households contain water and electricity.

In respect of facilities II (bathroom and latrine) the housing state appears poor but is less poor than in respect of facilities I. In terms of both facilities, native households appear poorer than migrant households. Among migrants, in-migrant households are poorer than migrant households.

There is widespread interest nowadays in the study of relationship between income and housing. Particularly low-cost housing for the lowincome people has become one of the important problems for housing and planning experts to tackle. These efforts are based on the widely known generalization that the lower a person's income is, the less he can spend on housing and the less adequate is his housing [7, p. 729]. This fact is not only relevant in the developed countries like the United States but also in the growing countries like Pakistan, where Karachi illustrates this point. Not only low income but also the peculiar problem of facilities for the two sexes makes the problem serious in the area of low-cost housing in Pakistan [18, p. 7].

\subsubsection{HOUSING CONDITIONS IN RELATION TO INCOME}

4.1.1 Households (Tables 16,17 and 18): Social and economic conditions prevailing in a household depend on the number of persons in a household and the income coming into it. Even if the income is high, the large household size makes it low on per capita basis, so that the consumption is affected and the level of living becomes low not an unusual fact illustrated in this study.

The following table demonstrates the relation between the size of the household and income:

Average Household Size by Income

\begin{tabular}{lc}
\hline Family income & $\begin{array}{c}\text { Average } \\
\text { household size }\end{array}$ \\
\hline All incomes & 4.4 \\
No income & 3.8 \\
Rs. $1-100$ & 3.5 \\
Rs. $100-200$ & 4.4 \\
Rs. $200-300$ & 5.4 \\
Rs. $300-500$ & 6.1 \\
Rs. 500 and over & 6.0 \\
\hline
\end{tabular}


The meaning that appears from the above table as well as the figure of frequency distribution is the increase in the average household size with the increase in income a fact consistent with similar findings in the cities, like, e.g., Calcutta [24, p. 58].

The medium and large-sized househlod are more frequent in higher than in lower income groups. This is because the number of earners in a family increases as the size of the family increases.

Average Earners per Family by Family Income

\begin{tabular}{lc} 
Family income & $\begin{array}{c}\text { Average } \\
\text { earners } \\
\text { per family }\end{array}$ \\
\hline All Incomes & 1.3 \\
No Income & - \\
Rs. 1-99 & 1.9 \\
Rs. $100-199$ & 1.3 \\
Rs. $200-299$ & 1.9 \\
Rs. 300-499 & 1.7 \\
Rs. 500 and over & 2.7 \\
No information & 1.8 \\
\hline
\end{tabular}

Consequently, there is increase in the income of a family as there is an increase in the number of earners. Therefore, big households in the case of rich people should not suggest overcrowding. Quality of housing (in terms of type of houses) is superior among rich people. Since houses of high income people are superior in built and are more spacious, there may not be actual overcrowding as merley the big household size suggests.

Despite the generalized occupational groups ${ }^{17}$, it can be said that people who are engaged in professional and managerial jobs live in big households whereas those engaged in transportation and sales

17 E.g., White collars (professionals, technical and related workers) contain in addition to such professionals as lawyers, educators, physicians and engineers, also moulvis and pirs, etc., Under executive and managers are included not only government and business executives but also petty shopkeepers. The social characteristics of moulvis and pirs on the one hand and those of engineers and lawyers on the other hand are poles apart and it will be deceptive to associate their characteristics with each other by keeping the both under one group. 
jobs live in small households. The former are the people of high income groups who as is noted above live in big households, though this does not suggest overcrowding because the quality of their houses is superior to those of low income group.

4.4.2 Type of Habitation (Table 19): Income also determines the type of houses people prefer in which they should live. Rich usually live in good quality houses because they can afford to. Low income people are forced to live in such poor houses as are within their paying capacity.

The findings of this survey support this hypothesis. A positive relationship exists between income and type of houses. As people move up the income scale, the quality of their houses (in terms of structure) improves: the proportion of people living in pucca houses increases and of those in juggies decreases. This is nothing unusual; it is a well known generalization.

However, there are the observation of an unusual nature: people in high income groups live in poor structures. These may be the extreme cases of those who despite high incomes have big family to support. This fact fails to stimulate investment on housing.

4.4.3 Tenure of Habitation (Table 20): It is revealed contrary to expsctation that owned houses are common among low income people and rented houses are common among high income people. This fact is contrary to the findings for the cities of developed countries like, United States where owners are found to have large income $[4$, p. 730].

The above fact when related with the findings that poor houses are owned to a greater degree than good houses and that poor houses are common among poor people brings out the reason why low-income people claim better house-ownership. In short, high income people who are frequent in rented houses live better than low income ones who are frequent in owned houses.

4.4.4 Facilities in Habitation (Tables 21 and 22): From the point of view of both type of facilities (water and electricity and bathroom and latrine), the living condition of high income people is super- 
ior as is expected. The data indicates that the state of housing among low income people is extremely poor. A large number of such people are devoid of such facilities. This is universally observed. "In the high industrialized countries, the social services and community facilities fail to satisfy the social cultural needs of the lower income groups [5, pp. 24-25].

In short, type of habitation and facilities in habitation indicate that the housing and living condition which is poor in Karachi is directly related to income. Increase in income means improvement in the state of housing and vice versa.

\subsubsection{SUMMARY AND CONCLUSION}

As a result of the partition of Indo-Pak subcontinent in 1947, fourteen to fifteen million people were exchanged between India and Pakistan with equal numbers coming in and going out. Among Pakistani cities, Karachi claimed the largest number of arrivals. In thirteen years' time, it quadrupled its population. The city, unable to cope with such a heavy inflow, displayed serious problems in respect of housing, community facilities and public utilities.

Housing and living problems were not only caused by immigration but perhaps also by not following the proper approach, i.e., understanding the problem before trying to do something about it. This study does not attempt to do more than expose some of the problems discovered in the "People of Karachi Survey 1959."

One-fourth of the pəople of Karachi were still shelterless living in 250 slum-clusters which were conspicuous by substandard juggies. Their living "... staggers human imagination." They were twice as over now than they were in 1951. Overcrowding was most serious in the central areas of Karachi. People live in physical environment characterised by indiscriminate mixture of land uses. Yet, there was a certain organization of land use. Typical residential areas have developed in the outskirts unless obstructed by physical limitations. The city does not have a master plan. Building and town planning regula tions, even if they exist, do not seem to be adhered to. 
In terms of such indices of overcrowding as persons per household (4.4), rooms per household (1.4), families per household (1.3) and persons per room (3.7), the picture appears poorer than in other surveyed cities of the growing countries of Asia and Africa.

About half of the people of Karachi live in houses whose structures (cement and masonry) indicate a reasonable living for occupants. Of the rest, two-thirds live in juggies which may be graded poorer than even probably the huts of the primitive communities. Also about half live in owned houses, but ownership is associated with poorer houses. A large number of households were devoid of such facilities as water, electricity and bathroom. Three-fourths of all households had neither bathroom nor latrine.

Within the generally poor state of housing of the people of Karachi, there were differences between socio-economic groups. Functional communities appeared to be relatively better than residential communities. People in upper residential, commercial, non-contiguous and labour areas appeared to live in better built and better-equipped houses, compared to industrial, lower residential and rural areas. Migrants displayed better state of housing than natives. Among migrants, immigrants were better off than in-migrants. The state of housing was found to be directly related to income, the higher the income the better the housing.

The socio-economic problems arising out of the aforementioned state of housing are many. The Lyari area which closely corresponds to the lower residential area, as defined in this study contained 17 per cent of the population of Karachi in 1959 but records 20 per cent of all serious crimes and 22 per cent of all cases of sickness of Karachi.

There was a need in 1959 of the immediate replacement of about one-third of dwelling units of Karachi. These are the juggy type of structures which cannot be termed even as "tolerable" huts. These numbered $1,49,675$. To these may be added half $(i . e ., 40,425)$ of the 
semi-pucca houses which may also need replacement. Thus, the figure of units to be replaced stands at 1,90,000. Assuming that about 5.6 per cent $(10,000)$ of the pucca houses are old and delapidated, the ultimate number of units deserving replacement goes to the tune of $2,00,000$

From 1959 to $1964,30,000$ dwellings have been built in Korangi town, 15,000 in North Karachi and about 10,000 in other areas of Karachi. This means that there is a backlog of about $1,45,000$ houses in Karachi. This is an immediate requirement. This estimate does not take account of the recurrent requirement.

During the last fifteen years, about 3,000 units of houses were built per year with private and government resources. The former was mostly luxury houses and the latter low-cost houses. Compared to similar endeavours elsewhere, this rate is quite fast. If houses continue to be built at the same rate then we can expect to meet the immediate shortage in twenty years' time. But by that time, the population would double itself. This would mean that the provision will not only have to be made for existing backlog but also for the recurrent demand arising out of the population growth and change from extended and joint to nucleus family system. This suggests that the existing rate of house building will have to be five to six times speedier if the immediate need is to be fulfilled in, say, five years' time and still more speedier if the rate has to take care of the prospective demand.

On the other hand, the resources of the government tell a sad tale. The Planning Commission, observes: "Under most favourable conditions, the country may have some $3,00,000$ new dwelling units during the plan period, besides a fair proportion of houses for government employees and industrial workers and houses constructed from contribution from local bodies." This, when considered in relation to the need seems to be very meagre. What is then needed is not only a "solution" but "correct solution" so that the problem is not only treated but also eliminated. 
TABLE 1

AVERAGE HOUSEHOLD SIZE BY MAJOR DIVISION: KARACHI, 1959

\begin{tabular}{lrcc}
\hline Major division & Population & Households & $\begin{array}{c}\text { Average } \\
\text { size of } \\
\text { households }\end{array}$ \\
\hline All areas & 72127 & 16373 & 4.4 \\
Commercial area & 15390 & 3435 & 4.5 \\
Industrial area & 4580 & 1205 & 3.8 \\
Lower residential area & 10294 & 2192 & 4.7 \\
Middle residential area & 19525 & 4242 & 4.6 \\
Upper residential area & 6363 & 1615 & 3.9 \\
Non-contiguous area & 2189 & 833 & 2.6 \\
Labour area & 10745 & 2245 & 4.9 \\
Rural area & 3041 & 606 & 5.0 \\
\hline
\end{tabular}




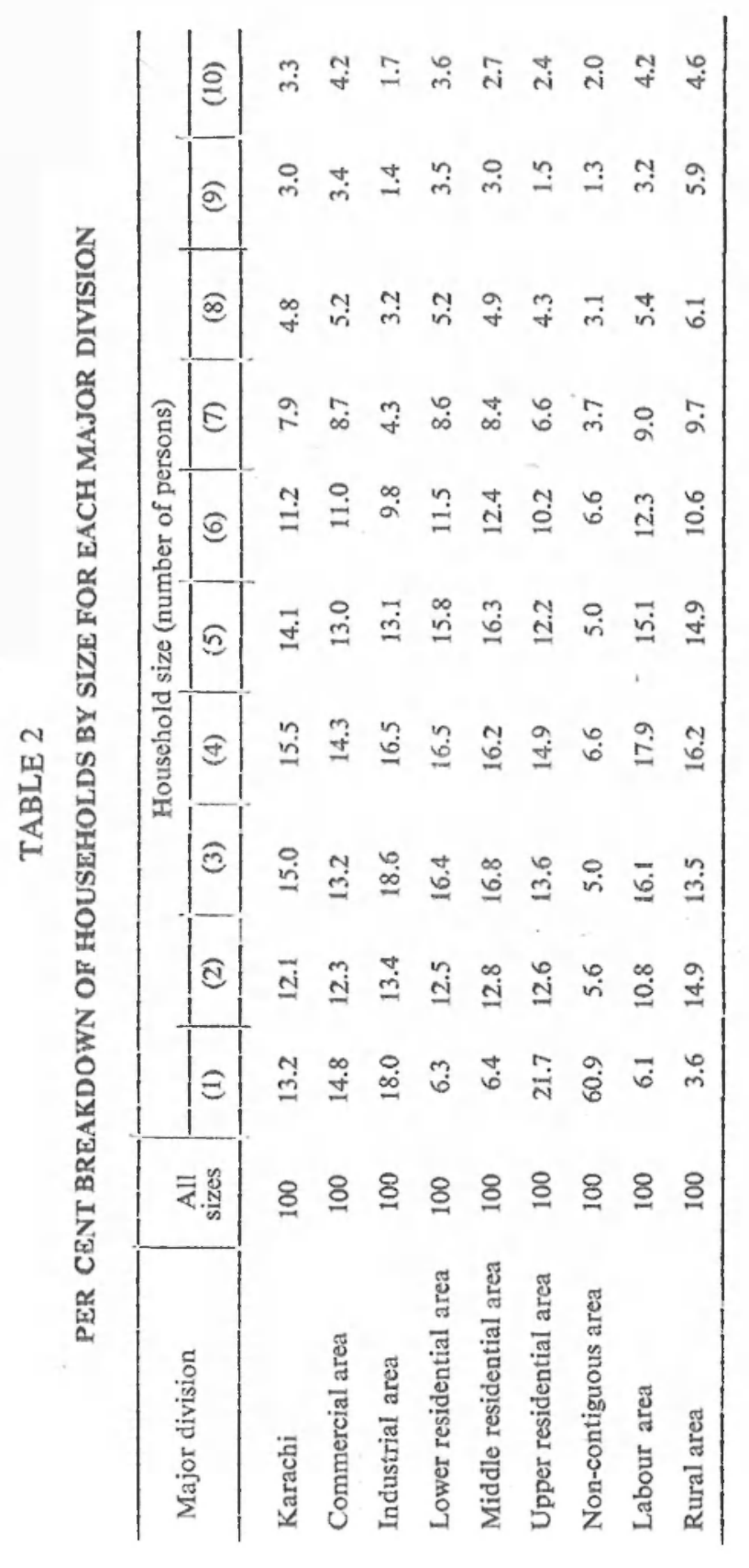


TABLE 3

PER CENT BREAKDOWN OF HOUSEHOLD SIZE GROUP BY MAJOR DIVISIONS

\begin{tabular}{|c|c|c|c|c|c|c|c|c|c|c|c|}
\hline \multirow{2}{*}{ Major division } & \multirow{2}{*}{$\underset{\text { persons }}{\text { All }}$} & \multicolumn{10}{|c|}{ Household size (number of persons) } \\
\hline & & 1 & 2 & 3 & 4 & 5 & 6 & 7 & 8 & 9 & 10 \\
\hline Commercial area & 21.3 & 23.6 & 21.3 & 18.4 & {$[19.3$} & 19.3 & 20.5 & 23.0 & 22.6 & 24.6 & 26.7 \\
\hline Industrial area & 6.3 & 10.1 & 8.1 & 9.2 & 7.9 & 6.8 & 6.4 & 4.0 & 5.1 & 3.5 & 3.6 \\
\hline Lower residential area & 14.3 & 6.5 & 13.7 & 14.6 & 14.3 & 15.0 & 13.8 & 14.6 & 14.5 & 15.7 & 14.8 \\
\hline Middle residential area & 27.1 & 12.7 & 27.4 & 29.2 & 27.2 & 30.0 & 28.7 & 27.5 & 26.0 & 26.3 & 21.7 \\
\hline Upper residential area & 8.8 & 16.3 & 10.3 & 8.9 & 9.5 & 8.5 & 9.0 & 8.4 & 8.7 & 5.2 & 7.6 \\
\hline Non-contiguous area & 3.0 & 23.5 & 2.4 & 1.7 & 2.2 & 1.8 & 3.0 & 2.4 & 3.3 & 2.3 & 2.9 \\
\hline Labour area & 14.9 & 6.4 & 12.2 & 14.7 & 15.8 & 14.6 & 15.1 & 15.6 & 15.3 & 14.8 & 17.3 \\
\hline Rural area & 4.2 & 10.1 & 4.6 & 3.3 & 3.9 & 3.9 & 3.5 & 4.6 & 4.7 & 7.5 . & 5.4 \\
\hline
\end{tabular}

TABLE 4

PER CENT DISTRIBUTION BY TYPE OF HABITATION AND MAJOR DIVISION

\begin{tabular}{lc|c|ccc}
\hline Major division & All types & \multicolumn{3}{c}{ Type of habitation } \\
\hline Karachi & 100 & 44.7 & 19.7 & 35.3 & 0.2 \\
Commercial area & 100 & 64.5 & 15.5 & 19.5 & 0.5 \\
Industrial area & 100 & 25.9 & 39.3 & 34.5 & 0.3 \\
Lower residential area & 100 & 30.4 & 18.9 & 50.5 & 0.2 \\
Middle residential area & 100 & 38.7 & 22.5 & 38.7 & 0.1 \\
Upper residential area & 100 & 37.7 & 23.1 & 39.0 & 0.2 \\
Non-contiguous area & 100 & 85.7 & 13.5 & 0.4 & 0.3 \\
Labour area & 100 & 55.9 & 11.7 & 32.3 & 0.1 \\
Rural area & 100 & 5.4 & 22.5 & 71.6 & 0.5 \\
\hline
\end{tabular}


TABLE 5

PER CENT DISTRIBUTION BY TENURE OF HABITATION AND MAJOR DIVISION

\begin{tabular}{|c|c|c|c|c|c|c|c|}
\hline \multirow[b]{2}{*}{ Major division } & \multirow{2}{*}{$\begin{array}{c}\text { All } \\
\text { persons }\end{array}$} & \multicolumn{6}{|c|}{ Tenure of habitation } \\
\hline & & Owners & Renter & Rent free & $\begin{array}{l}\text { No } \\
\text { regular } \\
\text { shelter }\end{array}$ & & \\
\hline Karachi & 100 & 54.3 & 29.0 & 15.8 & 0.1 & 0.7 & 0.8 \\
\hline Commercial area & 100 & 20.4 & 55.7 & 23.2 & 0.1 & 0.5 & 0.6 \\
\hline Industrial area & 100 & 61.0 & 19.7 & 19.0 & 一 & 0.4 & 0.4 \\
\hline Lower residential area & 100 & 66.0 & 29.3 & 4.6 & 0.1 & 一 & 0.1 \\
\hline Middle residential area & 100 & 58.3 & 26.1 & 15.4 & 0.1 & 0.1 & 0.2 \\
\hline Upper residential area & 100 & 46.2 & 24.2 & 29.0 & 一 & 0.6 & 0.6 \\
\hline Non-contiguous area & 100 & - & 31.5 & 68.1 & 一 & 0.4 & 0.4 \\
\hline Labour area & 100 & 86.9 & 9.1 & 1.0 & 一 & 3.0 & 0.3 \\
\hline Rural area & 100 & 93.2 & 4.8 & 0.8 & 0.5 & 0.8 & 0.13 \\
\hline
\end{tabular}

TABLE 6

PER CENT DISTRIBUTION BY FACILITIES IN THE HOUSEHOLDS (WATER \& ELECTRICITY) AND MAJOR DIVISIONS

\begin{tabular}{|c|c|c|c|c|c|c|}
\hline \multirow[b]{2}{*}{ Major division } & \multirow{2}{*}{$\begin{array}{c}\text { All } \\
\text { households }\end{array}$} & \multicolumn{5}{|c|}{ Water and electricity } \\
\hline & & $\begin{array}{l}\text { Both } \\
\text { water and } \\
\text { electricity }\end{array}$ & $\begin{array}{l}\text { Water, no } \\
\text { electricity }\end{array}$ & $\begin{array}{l}\text { Electricity, } \\
\text { no water }\end{array}$ & Neither & $\begin{array}{c}\text { No regular } \\
\text { shelter }\end{array}$ \\
\hline Karachi & 100 & 16.6 & 3.0 & 6.4 & 73.7 & 0.3 \\
\hline Commercial area & 100 & 29.1 & 5.2 & 9.6 & 55.7 & 0.3 \\
\hline Industrial area & 100 & 2.5 & 一 & 10.4 & 86.5 & 0.5 \\
\hline Lower residential area & 100 & 3.9 & 1.4 & 0.2 & 94.3 & 0.2 \\
\hline Middle residential area & 100 & 24.2 & 1.0 & 2.7 & 71.8 & 0.3 \\
\hline Upper residential area & 100 & 25.5 & 9.4 & 0.4 & 64.6 & 1.9 \\
\hline Non-contiguous area & 100 & 17.5 & 8.3 & 32.1 & 42.1 & 一 \\
\hline Labour area & 100 & 0.5 & 1.2 & 4.6 & 93.6 & - \\
\hline Rural area & 100 & 3.8 & 一 & - & 95.7 & 0.5 \\
\hline
\end{tabular}


TABLE 7

PER CENT DISTRIBUTION OF HOUSEHOLDS WITH BATHROOM AND LATRINE BY MAJOR DIVISION

\begin{tabular}{lcccccc}
\multicolumn{1}{c}{ Major division } & $\begin{array}{c}\text { All } \\
\text { Households }\end{array}$ & $\begin{array}{c}\text { Bath and } \\
\text { latrine }\end{array}$ & $\begin{array}{c}\text { Bath, } \\
\text { no latrine }\end{array}$ & $\begin{array}{c}\text { Latrine, } \\
\text { no bath }\end{array}$ & $\begin{array}{c}\text { Neither bath } \\
\text { nor latrine }\end{array}$ & $\begin{array}{c}\text { No regular } \\
\text { shelter }\end{array}$ \\
\hline Karachi & 100 & 46.1 & 2.7 & 12.2 & 38.9 & 0.2 \\
Commercial area & 100 & 43.6 & 1.5 & 7.2 & 47.4 & 0.4 \\
Industrial area & 100 & 33.9 & 3.0 & 14.7 & 48.3 & 0.2 \\
Lower residential area & 100 & 39.9 & 7.5 & 9.9 & 42.3 & 0.5 \\
Middle residential area & 100 & 54.0 & 0.8 & 19.5 & 25.7 & 0.2 \\
Upper residential area & 100 & 41.5 & 4.6 & 10.8 & 43.0 & 0.2 \\
Non-contiguous area & 100 & 48.2 & 3.0 & 10.0 & 39.2 & - \\
Labour area & 100 & 58.7 & 1.4 & 8.8 & 31.1 & 69.1 \\
Rural area & 100 & 15.2 & 3.8 & 11.4 & 6.5 \\
\hline
\end{tabular}

TABLE 8

PER CENT DISTRIBUTION OF POPULATON BY MIGRANT STATUS AND HOUSE,HOLD SIZE

\begin{tabular}{|c|c|c|c|c|c|c|c|c|c|c|c|c|c|}
\hline \multirow{2}{*}{$\begin{array}{l}\text { Migrant status } \\
\text { (1) }\end{array}$} & \multirow{2}{*}{$\begin{array}{l}\text { All } \\
(2)\end{array}$} & \multicolumn{12}{|c|}{ Household size (number of persons) } \\
\hline & & (3) & (4) & (5) & (6) & (7) & (8) & (9) & $(10)$ & $(11)$ & (12) & (13) & (14) \\
\hline Karachi & 100 & 100 & 100 & 100 & 100 & 100 & 100 & 100 & 100 & 100 & 100 & 100 & 100 \\
\hline Natives & 14.9 & 5.3 & 14.3 & 14.4 & 15.5 & 16.0 & 16.8 & 19.9 & 20.0 & 20.8 & 18.0 & 27.0 & 22.6 \\
\hline Migrants & $\begin{array}{l}85.0 \\
(100)\end{array}$ & $\begin{array}{c}94.5 \\
(100)\end{array}$ & $\begin{array}{r}85.6 \\
(100)\end{array}$ & $\begin{array}{l}86.6 \\
(100)\end{array}$ & $\begin{array}{r}84.3 \\
(100)\end{array}$ & $\begin{array}{r}83.9 \\
(100)\end{array}$ & $\begin{array}{l}83.2 \\
(100)\end{array}$ & $\begin{array}{l}80.1 \\
(100)\end{array}$ & $\begin{array}{r}80.0 \\
(100)\end{array}$ & $\begin{array}{r}79.2 \\
(100)\end{array}$ & $\begin{array}{r}82.0 \\
(100)\end{array}$ & $\begin{array}{r}73.0 \\
(100)\end{array}$ & $\begin{array}{r}77.4 \\
(100)\end{array}$ \\
\hline In-migrants & $\begin{array}{c}23.1 \\
(27.2)\end{array}$ & $\begin{array}{c}53.2 \\
(56.3)\end{array}$ & $\begin{array}{c}23.8 \\
(27.8)\end{array}$ & $\begin{array}{r}21.3 \\
(24.9)\end{array}$ & $\begin{array}{c}19.2 \\
(22.8)\end{array}$ & $\begin{array}{c}18.9 \\
(22.5)\end{array}$ & $\begin{array}{l}15.3 \\
(18.4)\end{array}$ & $\begin{array}{c}14.5 \\
(18.1)\end{array}$ & $\begin{array}{c}13.4 \\
(16.7)\end{array}$ & $\begin{array}{c}12.7 \\
(16.0)\end{array}$ & $\begin{array}{c}15.8 \\
(44.3)\end{array}$ & $\begin{array}{c}11.5 \\
(15.7)\end{array}$ & $\begin{array}{c}9.7 \\
(12.5)\end{array}$ \\
\hline Immigrants & $\begin{array}{c}61.9 \\
(72.8)\end{array}$ & $\begin{array}{c}41.3 \\
(43.7)\end{array}$ & $\begin{array}{l}61.8 \\
(72.2)\end{array}$ & $\begin{array}{c}64.3 \\
(75.1)\end{array}$ & $\begin{array}{c}65.1 \\
(77.2)\end{array}$ & $\begin{array}{c}65.0 \\
(77.5)\end{array}$ & $\begin{array}{l}67.9 \\
(81.6)\end{array}$ & $\begin{array}{c}65.6 \\
(81.9)\end{array}$ & $\begin{array}{c}66.6 \\
(83.3)\end{array}$ & $\begin{array}{c}66.5 \\
(84.0)\end{array}$ & $\begin{array}{c}66.2 \\
(55.7)\end{array}$ & $\begin{array}{l}61.5 \\
(87.3)\end{array}$ & $\begin{array}{c}67.7 \\
(87.5)\end{array}$ \\
\hline No information & 0.1 & 0.1 & 0.1 & $\rightarrow$ & 0.2 & 0.1 & - & - & - & - & - & - & - \\
\hline
\end{tabular}


TABLE 9 PER CENT DISTRIBUTION OF POPULATION BY TYF E OF HABITATION AND MIGRANT STATUS

\begin{tabular}{|c|c|c|c|c|c|}
\hline \multirow[b]{2}{*}{$\begin{array}{l}\text { Migrant status } \\
\text { (1) }\end{array}$} & \multirow[b]{2}{*}{$\begin{array}{l}\text { All persons } \\
\text { (2) }\end{array}$} & \multicolumn{4}{|c|}{ Type of habitation } \\
\hline & & $\begin{array}{l}\text { Pucca } \\
\text { (3) }\end{array}$ & $\begin{array}{l}\text { Semi } \\
\text { pucca } \\
(4)\end{array}$ & $\begin{array}{c}\text { Juggi } \\
\text { (5) }\end{array}$ & $\begin{array}{c}\text { Others } \\
(6)\end{array}$ \\
\hline Karachi & 100 & 44.7 & 19.7 & 35.3 & 0.2 \\
\hline Natives & 100 & 30.5 & 23.6 & 45.7 & 0.2 \\
\hline Migrants & 100 & 47.7 & 19.1 & 33.0 & 0.2 \\
\hline In-migrants & 100 & 37.2 & 24.2 & 38.1 & 0.4 \\
\hline Immigrants & 100 & 50.5 & 17.7 & 31.6 & 0.2 \\
\hline No information & 100 & 32.9 & 8.6 & 58.1 & 0.4 \\
\hline
\end{tabular}

TABLE 10

PER CENT DISTRIBUTION OF POPULATION BY MIGRANT STATUS AND TYPE OF HABITATION

\begin{tabular}{|c|c|c|c|c|c|c|}
\hline \multirow[b]{2}{*}{$\begin{array}{c}\text { Migrant status } \\
\text { (1) }\end{array}$} & & \multirow[b]{2}{*}{$\begin{array}{c}\text { All persons } \\
\text { (2) }\end{array}$} & \multicolumn{4}{|c|}{ Type of habitation } \\
\hline & & & $\begin{array}{l}\text { Pucca } \\
\text { (3) }\end{array}$ & $\begin{array}{c}\text { Semi pucca } \\
\text { (4) }\end{array}$ & $\underset{(5)}{J u g g i}$ & $\begin{array}{c}\text { Others } \\
(6)\end{array}$ \\
\hline Karachi & & 100.0 & 100.0 & 100.0 & 100.0 & 100.0 \\
\hline Natives & & 16.6 & 11.4 & 19.9 & 21.6 & 11.1 \\
\hline Migrants & & $\begin{array}{c}82.7 \\
(100.0)\end{array}$ & $\begin{array}{c}88.1 \\
(100.0)\end{array}$ & $\begin{array}{c}79.8 \\
(100.0)\end{array}$ & $\begin{array}{c}77.3 \\
(100.0)\end{array}$ & $\begin{array}{r}87.7 \\
(100.0)\end{array}$ \\
\hline In-migrants & & 98.9 & 97.8 & 100.0 & 99.9 & 87.6 \\
\hline Immigrants & & $\begin{array}{c}1.1 \\
(100.0)\end{array}$ & $\begin{array}{c}2.2 \\
(100.0)\end{array}$ & $(100 \overline{0})$ & $\begin{array}{r}0.1 \\
(100.0)\end{array}$ & $\begin{array}{r}12.4 \\
(100.0)\end{array}$ \\
\hline No information & & .. 6.9 & 0.5 & 0.3 & 1.0 & 1.2 \\
\hline
\end{tabular}


TABLE 11 PER CENT DISTRIBUTION OF POPULATION BY TENURE OF HABITATION AND MIGRANT STATUS

\begin{tabular}{lccccc} 
Migrant status & All persons & Owner & Renter \\
$(1)$ & $(2)$ & $(3)$ & $\begin{array}{c}\text { Rent free } \\
(5)\end{array}$ & $\begin{array}{c}\text { Others } \\
(6)\end{array}$ \\
\hline Karachi & 100 & 54.4 & 29.0 & 15.8 & 0.8 \\
Natives & 100 & 7.1 & 20.6 & 9.0 & 0.3 \\
Migrants & 100 & 51.6 & 30.9 & 17.1 & 0.4 \\
In-migrants & 100 & 42.2 & 35.4 & 21.2 & 1.2 \\
Immigrants:India & 100 & 54.6 & 29.2 & 16.0 & 0.1 \\
Immigrants: other countries & 100 & 54.2 & 29.7 & 16.0 & 0.3 \\
No Information & 100 & 3.0 & 73.8 & 20.7 & 2.4 \\
\hline
\end{tabular}

TABLE 12

PER CENT DISTRIBUTION BY TYPE OF HABITATION AND TENURE OF HABITATION

\begin{tabular}{lccccc}
\hline & All types & Pucca & $\begin{array}{c}\text { Semi } \\
\text { pucca }\end{array}$ & $\boldsymbol{J}_{\text {llggi }}$ & Others \\
\hline All Tenures & 100 & 44.7 & 19.7 & 35.3 & 2.3 \\
Owned & 100 & 23.7 & 20.6 & 55.6 & 0.1 \\
Rented & 100 & 76.2 & 16.3 & 5.6 & 1.9 \\
Rent free & 100 & 55.0 & 24.5 & 20.0 & - \\
Others & 100 & 15.9 & 9.6 & 5.7 & 1.7 \\
\hline
\end{tabular}


TABLE 13 PER CENT DISTRIBUTION OF POPULATION BY TENURE OF HABITATION AND MIGRANT STATUS

\begin{tabular}{|c|c|c|c|c|c|}
\hline \multirow[b]{2}{*}{$\begin{array}{l}\text { Migrant status } \\
\text { (1) }\end{array}$} & \multirow[b]{2}{*}{$\begin{array}{l}\text { All persons } \\
\text { (2) }\end{array}$} & \multicolumn{4}{|c|}{ Tenure of habitation } \\
\hline & & $\begin{array}{c}\text { Owned } \\
\text { (3) }\end{array}$ & $\begin{array}{l}\text { Rented } \\
\text { (4) }\end{array}$ & $\begin{array}{c}\text { Rent free } \\
(5)\end{array}$ & $\begin{array}{l}\text { Others } \\
\text { (6) }\end{array}$ \\
\hline Karachi & 100.0 & 100.0 & 100.0 & 100.0 & 100.0 \\
\hline Natives & 16.6 & 21.5 & 11.8 & 9.5 & 5.5 \\
\hline Migrants & $\begin{array}{l}82.7 \\
(100)\end{array}$ & $\begin{array}{l}78.5 \\
(100)\end{array}$ & $\begin{array}{l}87.9 \\
(100)\end{array}$ & $\begin{array}{l}89.5 \\
(100)\end{array}$ & $\begin{array}{l}38.0 \\
(100)\end{array}$ \\
\hline In-migrants & 21.2 & 17.3 & 24.3 & 26.2 & 71.5 \\
\hline Imigrants & 82.7 & 72.8 & 75.7 & 73.8 & 28.5 \\
\hline No information & 0.7 & - & 0.3 & 0.9 & 56.5 \\
\hline
\end{tabular}

TABLE 14

PER CENT DISTRIBUTION OF HOUSEHOLDS WITH WATER AND ELECTRICITY BY MIGRANT STATUS

\begin{tabular}{lccccccc}
\hline Migrant status & All households & $\begin{array}{c}\text { Both } \\
\text { available } \\
(1)\end{array}$ & $\begin{array}{c}\text { Only } \\
\text { water } \\
(4)\end{array}$ & $\begin{array}{c}\text { Onlec } \\
\text { electricity } \\
(5)\end{array}$ & $\begin{array}{c}\text { None } \\
\text { available } \\
(6)\end{array}$ & $\begin{array}{c}\text { Shelter } \\
\text { not reported } \\
(7)\end{array}$ \\
\hline Karachi & 100 & 16.5 & 3.0 & 6.4 & 73.7 & 0.3 \\
Natives & 100 & 11.8 & 2.3 & 5.7 & 80.0 & 0.2 \\
Migrants & 100 & 17.4 & 3.1 & 6.6 & 72.7 & 0.3 \\
In-migrants & 100 & 13.4 & 5.1 & 10.2 & 70.7 & 0.6 \\
Immigrats & 100 & 18.9 & 2.3 & 5.2 & 73.4 & 0.1 \\
\hline
\end{tabular}


TABLE 15 PER CENT DISTRIBUTION OF HOUSEHOLDS WITH BATH OR LATRINE BY MIGRANT STATUS

\begin{tabular}{|c|c|c|c|c|c|c|}
\hline \multirow[b]{2}{*}{$\begin{array}{c}\text { Migrant status } \\
\text { (1) }\end{array}$} & \multirow[b]{2}{*}{$\begin{array}{c}\text { All } \\
\text { households } \\
\text { (2) }\end{array}$} & \multicolumn{5}{|c|}{ Bath and latrine } \\
\hline & & $\begin{array}{l}\text { Both } \\
\text { available } \\
\text { (3) }\end{array}$ & $\begin{array}{l}\text { Only } \\
\text { bath } \\
(4)\end{array}$ & $\begin{array}{l}\text { Only } \\
\text { latrine } \\
\text { (4) }\end{array}$ & $\underset{(5)}{\text { Neither }}$ & $\begin{array}{c}\text { Shelter } \\
\text { not reported } \\
\text { (7) }\end{array}$ \\
\hline Karachi & 100 & 46.1 & 2.7 & 12.2 & 38.9 & 0.3 \\
\hline Natives & 100 & 37.1 & 8.9 & 4.9 & 59.0 & 0.2 \\
\hline Migrants & 100 & 49.3 & 1.5 & 13.4 & 35.4 & 0.3 \\
\hline In-migrants & 100 & 32.8 & 2.3 & 7.0 & 57.3 & 0.6 \\
\hline Immigrants & 100 & 55.5 & 1.4 & 15.8 & 27.3 & 0.1 \\
\hline
\end{tabular}

TABLE 16 PER CENT DISTRIBUTION OF FAMILIES BY HOUSEHOLD SIZE AND FAMILY INCOME

\begin{tabular}{|c|c|c|c|c|c|c|c|c|c|c|c|c|c|}
\hline \multirow{2}{*}{ Family income } & \multirow{2}{*}{$\begin{array}{c}\text { All } \\
\text { sizes }\end{array}$} & \multicolumn{12}{|c|}{ House size (number of persons) } \\
\hline & & 1 & 2 & 3 & 4 & 5 & 6 & 7 & 8 & 9 & 10 & 11 & 12 \\
\hline \multicolumn{2}{|l|}{ All incomes 100} & 13.2 & 12.1 & 15.0 & 15.5 & 14.1 & 11.2 & 7.9 & 4.8 & 2.9 & 1.7 & 0.7 & 0.9 \\
\hline No income & 100 & 34.3 & 12.5 & 20.3 & 7.0 & 8.4 & 7.0 & 4.9 & 5.6 & - & - & - & - \\
\hline Rs. $1-99$ & 100 & 20.7 & 17.0 & 17.0 & 16.2 & 12.5 & 9.2 & 4.9 & 2.0 & 1.1 & 0.4 & 0.1 & - \\
\hline Rs. $100-199$ & 100 & 10.9 & 12.6 & 16.3 & 16.9 & 15.0 & 10.9 & 8.1 & 4.7 & 2.4 & 1.2 & - & 一 \\
\hline Rs. 200-299 & 100 & 6.4 & 6.8 & 11.1 & 14.3 & 15.7 & 13.5 & 12.5 & 7.7 & 6.4 & 3.2 & 1.6 & 0.9 \\
\hline Rs. $300-499$ & 100 & 4.0 & 3.8 & 7.9 & 11.9 & 17.3 & 16.4 & 11.3 & 9.4 & 6.8 & 5.3 & 2.2 & 3.8 \\
\hline Rs. 500 and ove & 100 & 2.2 & 6.7 & 10.5 & 10.0 & 11.9 & 15.2 & 11.8 & 12.5 & 5.6 & 4.8 & 2.5 & 6.3 \\
\hline
\end{tabular}


TABLE 17

PER CENT DISTRIBUTION OF OCCUPATIONAL GROUPS BY HOUSEHOLD SIZE

\begin{tabular}{|c|c|c|c|c|c|c|c|c|c|c|c|c|c|}
\hline Occupational group & \multirow{2}{*}{$\begin{array}{l}\text { All- } \\
\text { per- } \\
\text { sons }\end{array}$} & \multirow{2}{*}{\multicolumn{12}{|c|}{ Household size (number of persons) }} \\
\hline Name & & & & & & & & & & & & & \\
\hline (1) & (3) & (4) & (5) & (6) & (7) & (8) & (9) & (10) & (11) & (12) & (13) & (14) & $(15)$ \\
\hline $\begin{array}{l}\text { All occupational groups } \\
\text { Professional and techni- }\end{array}$ & $\begin{array}{l}100 \\
100\end{array}$ & $\begin{array}{r}3.0 \\
10.7\end{array}$ & $\begin{array}{r}5.5 \\
10.5\end{array}$ & $\begin{array}{l}16.2 \\
13.9\end{array}$ & $\begin{array}{r}14.1 \\
9.5\end{array}$ & $\begin{array}{l}16.0 \\
16.9\end{array}$ & $\begin{array}{r}15.2 \\
9.5\end{array}$ & $\begin{array}{l}12.6 \\
10.7\end{array}$ & $\begin{array}{l}8.8 \\
6.4\end{array}$ & $\begin{array}{l}6.0 \\
4.4\end{array}$ & $\begin{array}{l}3.8 \\
3.0\end{array}$ & $\begin{array}{l}1.9 \\
3.9\end{array}$ & $\begin{array}{l}3.0 \\
0.7\end{array}$ \\
\hline $\begin{array}{l}\text { cians } \\
\text { Administration \& man- }\end{array}$ & 100 & 4.4 & 10.6 & 10.6 & 13.2 & 13.7 & 15.0 & 8.4 & 8.0 & 6.4 & 3.7 & 2.2 & 3.8 \\
\hline Clerks & 100 & 12.9 & 8.7 & 14.1 & 13.5 & 15.4 & 10.1 & 9.0 & 6.3 & 4.3 & 3.1 & 1.3 & 1.4 \\
\hline Sales workers & 100 & 3.6 & 12.4 & 13.8 & 17.0 & 14.6 & 14.0 & 10.3 & 6.0 & 3.8 & 2.4 & 0.7 & 1.2 \\
\hline Farmers \& fishermen & 100 & 3.0 & 7.7 & 12.2 & 16.1 & 15.3 & 10.9 & 9.3 & 8.2 & 7.2 & 4.9 & 0.9 & 4.3 \\
\hline Drivers, postmen and & 100 & 18.7 & 9.4 & 11.8 & 15.4 & 13.5 & 10.6 & 9.7 & 4.5 & 2.5 & 1.3 & 1.2 & 1.3 \\
\hline Skilled labour & 100 & 9.9 & 8.8 & 14.4 & 15.7 & 14.8 & 11.6 & 8.8 & 6.2 & 4.5 & 2.1 & 1.4 & 1.7 \\
\hline Unskilled labour & 100 & 8.1 & 10.4 & 15.9 & 15.6 & 16.4 & 11.8 & 9.3 & 5.4 & 3.1 & 1.9 & 1.0 & 1.1 \\
\hline Servants \& related & 100 & 14.9 & 10.8 & 14.2 & 13.3 & 14.0 & 11.5 & 8.3 & 4.8 & 2.6 & 2.5 & 1.1 & 2.1 \\
\hline Not classifiable & 100 & 6.8 & 9.4 & 12.7 & 14.0 & 14.9 & 13.0 & 11.6 & 7.7 & 4.5 & 2.5 & 1.1 & 2.0 \\
\hline Unemployed & 100 & 3.4 & 6.8 & 11.0 & 15.7 & 14.1 & 13.1 & 11.4 & 8.4 & 5.4 & 3.7 & 2.5 & 4.8 \\
\hline Not in labour force & 100 & 0.2 & 3.5 & 8.6 & 13.8 & 16.6 & 16.7 & 14.0 & 9.9 & 6.9 & $4: 4$ & 2.2 & 3.3 \\
\hline
\end{tabular}

TABLE 18

AVERAGE HOUSEHOLD SIZE BY OCCUPATIONAL GROUP

\begin{tabular}{lccc}
\hline Occupational group of principal earners & Population & Households & $\begin{array}{c}\text { average house- } \\
\text { hold size }\end{array}$ \\
\hline All occupational groups & $1,803,175$ & 409.325 & 4.4 \\
Professional and technicians & 51,825 & 11,000 & 4.7 \\
Administrators and managers & 213,700 & 40,125 & 5.3 \\
Clerical workers & 63,925 & 14,575 & 4.4 \\
Sales workers & 145,575 & 31,600 & 4.6 \\
Farmers and fishermen & 67,450 & 13,300 & 5.1 \\
Drivers, postmen & 109,150 & 27,600 & 3.9 \\
Skilled labourers & 300,675 & 68,800 & 4.4 \\
Semi-skilled and unskilled labourers & 273,300 & 67,375 & 4.8 \\
Servant and related & 178,275 & 46,375 & 3.8 \\
Workers not classifiable & 347,700 & 74,025 & 4.7 \\
Employed & 12,175 & 3,100 & 3.9 \\
Persons not in labour force & 39,425 & 11,450 & 3.4 \\
\hline
\end{tabular}


TABLE 19

PER CENT DISTRIBUTION OF POPULATION BY TYPE OF HABITATION AND FAMILY INCOME GROUPS

\begin{tabular}{lc|ccc|c}
\hline $\begin{array}{l}\text { Family income } \\
(1)\end{array}$ & $\begin{array}{c}\text { All persons } \\
(2)\end{array}$ & $\begin{array}{c}\text { Pucca } \\
(3)\end{array}$ & $\begin{array}{c}\text { Semi pucca } \\
(4)\end{array}$ & $\begin{array}{c}\text { Juggi } \\
(5)\end{array}$ & $\begin{array}{c}\text { Others } \\
(6)\end{array}$ \\
\hline Karachi & 100 & 44.7 & 19.7 & 35.3 & 0.2 \\
No income & 100 & 55.2 & 15.1 & 29.5 & 0.2 \\
Rs. 1-99 & 100 & 26.0 & 19.9 & 53.8 & 0.3 \\
Rs. 100-199 & 100 & 38.2 & 23.3 & 38.2 & 0.2 \\
Rs. 200-299 & 100 & 58.3 & 19.6 & 21.9 & 0.2 \\
Rs. 300-499 & 100 & 69.8 & 16.6 & 13.5 & 0.1 \\
Rs. 500 and over & 100 & 90.0 & 5.7 & 4.2 & - \\
No information & 100 & 52.1 & 15.8 & 31.6 & 0.5 \\
\hline
\end{tabular}

TABLE 20

PER CENT BREAKDOWN BY TENURE OF HABITATION FOR EACH FAMILY INCOME GROUP

\begin{tabular}{|c|c|c|c|c|c|}
\hline \multirow{2}{*}{$\begin{array}{c}\text { Family income } \\
\text { (1) }\end{array}$} & \multirow{2}{*}{$\begin{array}{l}\underset{\text { All }}{\text { persons }} \\
(3)\end{array}$} & \multicolumn{4}{|c|}{ Tenure of habitation } \\
\hline & & $\begin{array}{c}\text { Owned } \\
(3)\end{array}$ & $\begin{array}{c}\text { Rented } \\
\text { (4) }\end{array}$ & $\begin{array}{l}\text { Rent free } \\
(5)\end{array}$ & $\begin{array}{l}\text { Others } \\
(6)\end{array}$ \\
\hline Karachi & 100 & 54.4 & 29.0 & 15.8 & 0.8 \\
\hline No income & 100 & 48.5 & 25.0 & 19.8 & 6.7 \\
\hline Rs. $1-99$ & 100 & 65.6 & 14.9 & 17.8 & 1.7 \\
\hline Rs. $100-199$ & 100 & 59.8 & 23.3 & 16.4 & 0.5 \\
\hline Rs. $200-299$ & 100 & 45.2 & 39.0 & 15.7 & 0.1 \\
\hline Rs. $300-497$ & 100 & 24.7 & 63.8 & 11.3 & 0.1 \\
\hline Rs. 500 and over & 100 & 35.9 & 52.0 & 11.9 & 0.2 \\
\hline No information & 100 & 56 & 33.6 & 9.0 & 0.2 \\
\hline
\end{tabular}


TABLE 21 FOR EACH FAMILY INCOME GROUP

\begin{tabular}{|c|c|c|c|c|c|c|}
\hline Family income group & All households & $\begin{array}{c}\text { Neither } \\
\text { availabile }\end{array}$ & $\begin{array}{c}\text { Both } \\
\text { available }\end{array}$ & $\begin{array}{c}\text { Only } \\
\text { water } \\
\text { available }\end{array}$ & $\begin{array}{l}\text { Only } \\
\text { electricity } \\
\text { available }\end{array}$ & $\begin{array}{l}\text { No regular } \\
\text { shelter or } \\
\text { not reported }\end{array}$ \\
\hline Kara chi & 100 & 16.6 & 3.0 & 6.4 & 73.7 & 0.3 \\
\hline No income & 100 & 12.6 & 1.4 & 7.7 & 77.7 & 0.7 \\
\hline Rs. $1-49$ & 100 & 5.0 & 2.9 & 2.9 & 87.4 & 1.9 \\
\hline Rs. $50-74$ & 100 & 3.8 & 4.5 & 3.5 & 87.8 & 0.5 \\
\hline Rs. $75-99$ & 100 & 4.9 & 2.3 & 3.7 & 89.1 & 0.1 \\
\hline Rs. $100-124$ & 100 & 7.0 & 2.7 & 5.5 & 84.6 & 0.2 \\
\hline Rs. $125-149$ & 100 & 12.4 & 3.7 & 7.4 & 76.5 & 一 \\
\hline Rs. $150-199$ & 100 & 14.2 & 2.4 & 9.0 & 74.3 & - \\
\hline Rs. $200-299$ & 100 & 27.0 & 2.9 & 11.9 & 58.0 & 0.1 \\
\hline Rs. $300-499$ & 100 & 45.2 & 3.6 & 9.3 & 41.9 & - \\
\hline Rs. $500-999$ & 100 & 72.8 & 1.5 & 5.9 & 19.8 & - \\
\hline Rs. 100 and over & 100 & 28.3 & 1.0 & 3.9 & 66.8 & - \\
\hline No Information & 100 & 92.5 & 0.7 & 2.9 & 2.9 & 1.1 \\
\hline
\end{tabular}

TABLE 22

PER CENT BREAKDOWN OF HOUSEHOLDS BY AVAILABILITY OF BATHROOM AND LATRINE FOR EAC,H FAMILY INCOME GROUP

\begin{tabular}{lcccccc}
\hline $\begin{array}{l}\text { Family income } \\
\text { (Rs.) }\end{array}$ & $\begin{array}{c}\text { All } \\
\text { households }\end{array}$ & $\begin{array}{c}\text { Both } \\
\text { available }\end{array}$ & $\begin{array}{c}\text { Only bath } \\
\text { room } \\
\text { available }\end{array}$ & $\begin{array}{c}\text { Only latrine } \\
\text { available }\end{array}$ & $\begin{array}{c}\text { Neither } \\
\text { available }\end{array}$ & $\begin{array}{c}\text { No regular } \\
\text { shelter or } \\
\text { not reported }\end{array}$ \\
\hline Karachi & 100 & 46.1 & 2.7 & 12.2 & 38.9 & 0.3 \\
No income & 100 & 55.2 & 1.4 & 11.9 & 30.7 & 0.7 \\
Rs. 1-49 & 100 & 28.7 & 3.1 & 15.5 & 50.9 & 1.9 \\
Rs. 50-74 & 100 & 27.2 & 1.9 & 14.3 & 56.0 & 0.5 \\
Rs. $75-99$ & 100 & 33.6 & 4.6 & 13.8 & 47.9 & 0.1 \\
Rs. 100-124 & 100 & 40.9 & 2.7 & 14.7 & 41.4 & 0.2 \\
Rs. 125-149 & 100 & 48.4 & 2.2 & 14.3 & 35.2 & - \\
Rs. $150-149$ & 100 & 46.7 & 2.7 & 14.0 & 36.5 & 0.1 \\
Rs. 200-299 & 100 & 59.7 & 3.0 & 9.2 & 28.1 & - \\
Rs. 300-499 & 100 & 75.2 & 1.8 & 4.0 & 19.1 & - \\
Rs. 500-999 & 100 & 89.6 & 0.8 & 1.1 & 8.5 & - \\
Rs. 1000 and over & 100 & 53.2 & 2.0 & 9.3 & 35.6 & - \\
No information & 100 & 97.8 & 0.4 & 0.7 & 1.1 \\
\hline
\end{tabular}




\section{REFERENCES}

1. Ahmad, Nazir (Lt. Col.), Shelterless Persons Survey, 1959. (Karachi: Central Statistical Office).

2. Ahmad, Nazir (Lt. Col.), Survey of Shelterless Persons in Karachi. (Karachi : Manager of Publications, 1959).

3. Bartholmew, Harland, and Associates, Karachi Water Supply Problems. (Karachi: Karachi Joint Water Bcard, 1952).

4. Bogue, Donald J., The Population of the United States. (Chicago: Free Press of Glencoe, 1959).

5. Cabrera, Gilbert R. (ed), Proceedings of the 1960 World Planing and Housing Congress, held San Juan, Puerto Rico,. May 28June 3, 1960. (San Juan: Inter-American Planning Society. Commonwealth of Puerto Rico, 1961).

6. Gist, Neol P. and L.A. Halbert, Urban Society. (New York: Thomas Y. Crowell Company, 1954).

7. Gottman, Jean, Megalopol's. (New York: Twentieth Century Fund, 1961).

8. Hashmi, Sultan S., Demographic Characteristics of the People of Karachi. (Karachi: Pakistan Institute of Development Economics, 1964).

9. Hashmi, S.S. et al. The People of Karachi: Data from A Survey. (Karachi: Pakistan Institute of Development Economics, 1964).

10. Jillani, M.S., The Resettlement Pattern of Displaced Persons in Pakistan. Ph.D. Thesis. (Chicago: University of Chicago, 1962).

11. Krotki, Karol J., "First Release from the Second Population Census of Pakistan, 1961", Pakistan Development Review, Vol. I, No. 2, Autumn 1961.

12. Mauldin, W. Parker and Sultan S. Hashmi, "Illustrative Esti mates and Projections of the Populations of Pakistan, 1951 to 1961", in M.L. Qureshi (ed), Population Growth and Economic Development with Special Reference to Pakistan. (Karachi: Pakistan Institute of Development Economics). 
13. Merrill, Francis E. and W. Wentworth Eldridce, Culture and Society. (New York: Prentice Hall).

14. Mumford, Lewis, Culture of Cities (New York: Harcourt Brace, 1938).

15. Pakistan, Central Statistical Office, Korangi Survey 1961. (Karachi: Central Statistical Office).

16. Pakistan, Central Statistical Office, Report on Sample Survey of Karachi Population, 1959. (Karachi: Manager of Publication, 1959).

17. Pakistan, Ekistic Training Centre, Surve's of Central Flats, Malir-Saudabad and Lyari Area. (Karachi: Pakistan Ekistic Training Centre).

18. Pakistan, Federal Capital Commission, President's Secretariat, Housing and Town Planning Committee, No. VII. Data and Suggestions. Dox-DA64 (Athens: Doxiadis Associates, Ist February, 1960).

19. Pakistan, Karachi Development Authority, Karachi: Land Use Pattern. Report No. MP-17. (Karachi: Karachi Development Authority, January 1963).

20. Pakistan, Karachi Development Authority, Karachi Primary and Secondary Schools. Report No. MP-18. (Karachi: Karachi Development Authority, January 1963).

21. Pakistan, Karachi Development Authority, Lyari Quarter's Survey. (Karachi: Karacini Development Authority).

22. Pakistan, Karachi Development Authority, The Lyari Development Scheme. Existing Conditions. (Karachi: KDA, 1961).

23. Pakistan, Office of the Census Commissioner, Ministry of Home and Kashmir Affairs, Home Affairs Division, Population Census of Pakistan, District Census Report: Karachi. (Karachi: Manager of Publications, 1963).

24. Sen, S.N., The City of Calcutta. A Socio-Economic Survey 1954-55 to 1957-58. (Calcutta: Bookland Private, 1960). 
25. Sp.te, O.H.K., India and Pakistan. (London: Methuen; New York: Dutton, 1954).

26. Uinited Nations, Community Development in Urban Areas. (New York: United Nations Department of Economic and Social Affairs, 1961).

27. United Nations, Department of Economic and Social Affairs, The Mysore Population Study, Population Studies: No. 34. (New York: United Nations, 1961).

28. Zorbaugh, Harvey W., quoted in [13]. 


\section{GLOSSARY}

\section{HABITATION}

Any structure or any space used by a household as a place of abode is called a habitation. All the habitations covered in the survey are classified by the type of structure and tenure.

By type of structure, the habitations are classified into five categories:

Pucca: A dwelling with all its walls and roof made entirely of bricks, stone or concrete is a pucca dwelling.

Semi-pucca: A dwelling made partly of pucca material and partly of katcha material, e.g., mud is semi-pucca structure.

Juggi: As commonly understood a dwelling made of straw, bamboocanvas, sacks or mats and/or some mud plaster.

Roof-top: Improvised shelter on the roof of a building.

No regular shelter: Space used for sleeping under open sky.

Tenure of habitation or dwelling unit is subdivided into three types.

Orvner-occupied: The unit is owned by a family, or families or group of persons, even though the plot of land on which the unit stands may be owned by someone else.

Rented: The unit is occupied on payment of rent.

Rent-free: The unit is occupied by a person or persons other than the owner of the unit and no payment of rent is involved.

It should be noted that the statistics presented on habitation in this volume pertain only to residential structures and spaces.

\section{HOUSEHOLD}

A household is a family or group of families or group of persons living together and eating at least one main meal a day from the same kitchen. There are three types of households. 
i) Family-type household: A household containing at least one family as defined is a family-type household.

ii) Partnership household: A household containing more than one person related or unrelated but no family is a partnership household.

iii) Single-person household: A household containing one person only is defined as single-person household.

Household size: The size of a household is determined by all persons enumerated in the survey as members of the household, including servants and lodgers. Lodgers who eat from a different kitchen make up in accordance with the definition of the household, a separate household.

Household head: A person who was reported as head of household was recorded as such on the first line of the schedule. A head of household is not necessarily the principal earner.

\section{FACILITIES IN THE HABITATION}

Such household questions were asked about the existence of the following facilities: $i$ ) Electricity; ii) Running water, iii) Bathroom; iv) Latrine. Community bathrooms and communal latrines are not considered as facilities available in habitation.

\section{FAMILIES AND INDIVIDUALS}

Families and individuals living in the households are classified according to family classification and individual's status in the household. It should be noted that a servant living in or a lodger does not affect the family classification.

Primary family: A multiple persons' household of an independent character when the members of the household are all related to the head by blood or marriage, excluding servants and lodgers.

Nuclear family: A primary family is a nuclear family if it consists of one of the following three types:

i) husband, wife, and never-married child/children

ii) husband and wife

iii) one parent and never married child/children. 
Extended family: A primary family is an extended family if it consists of a nuclear family, as defined, plus one or more other relatives (related either to the head or to the spouse) sharing economic and living arrangements.

Joint family: A primary family is a joint family if it consists of a nuclear family, as defined, plus one or more subfamilies, as defined, with or without other relatives sharing economic and living arrangements.

Subfamily: A married couple (and their never-married children, if any) or a parent with one or more never-married children, related to the head or spouse of the head of primary family and sharing economic and living arrangements. If such a family lives on its own (with nobody else) in a household it becomes a primary family.

Nonfamily-type persons: Persons who do not form a family by themselves.

Secondary individual: A person who is neither a head nor is related to the head of household by blood or marriage, but lives in the same household sharing boarding and living arrangement is a secondary individual (example: servant, lodger, etc.)

\section{INCOME}

Personal income: A sum of individual's income (earned and received from other sources) in the month preceding the month of enquiry is personal income. Pension, rent received, etc. are examples of income from other sources.

Family income: Sum of the personal incomes of all individuals related to the head of a household by blood or marriage is family income. The family income of a secondary individual is the same as his personal income.

\section{LABOUR FORCE}

Labour force: All persons who were gainfully employed or were actively seeking job at the time of enquiry are included in the labour force. Unpaid family workers are also included in this category. 
Working labour-force: All persons who were pursuing a gainful occupation at the time of the enquiry are included in the working labourforce. In other words, labour force minus the unemployed constitutes working labour-force. Unpaid family workers are also included in this category.

Unemployed: All persons who were not working but claimed to be looking for work at the time of the enquiry are reported as unemployed.

Persons not in labour force: All those persons who were neither gainfully employed nor actively seeking work at the time of the enquiry belong to this category. More specifically, students, pensioners, retired persons, housewives, dependents of all ages, and all persons whose occupations were not reported at the time of enquiry are included in this category.

Persons not norking: All those persons who are either unemployed or not in labour force are included in this category.

\section{MARITAL STATUS}

Single: This category refers to the persons who were never married.

Married: This category includes persons who were married at the time of the survey, whether the first time or whether remarried after having been widowed or divorced. This category is further divided in case of married females into:

i) Married, husband present, and

ii) Married, husband absent: If a husband is enumerated as a member of the household, even though he may be temporarily absent, the wife is placed under category i). If a husband is enumerated as working in city or district away from Karachi, the wife is placed under category ii). It is suspected that some married persons, with spouse absent, might have been reported as separated.

Married couple: This concept as used in the tables means a husband and his wife in monogamous union or a husband and his first wife in polygynous union.

\section{MIGRANT STATUS}

The entire population enumerated is classified into three categories: i) migrant, ii) native and iii) no information. 
Migrant: A migrant is a person whose family's original place of residence is not Karachi. The head and all persons who are related to the head are given the same migrant status as shown on the schedule. Thus, children of migrants born in Karachi and natives who moved into migrant families by marriage are also considered migrants. Persons who are not related to the head of family are not given any migrant status. The migrants are further subdivided into two categories.

i) In-migrant: Migrant (as defined) whose original place of residence is in Pakistan (excluding Karachi).

ii) Immigrant: Migrant (as defined) whose original place of residence is outside Pakistan. About 99 percent of the immigrants are migrants from various states of India and the rest from other countries and territories of the world. As the proportion of migrants from countries other than India is very small to make significant difference in the results they have been lumped together with the migrants from India.

Native: A native is a person whose family's original place of residence is Karachi.

No information: Persons belonging to families whose migrant status was not reported plus the persons who were not related to the head of household (servants and lodgers, etc.) were placed under this category.

\section{EDUCATION}

Enrolment Status: Status of school age persons being in one of the following categories:

1. Persons in school

2. Persons not in school

Persons not in school are further subdivided into three categories namely i) Apprentices ii) working iii) not working.

School Age Persons: The persons in the age of 5 years to twenty years.

Persons in School: The persons reported as students including those receiving education in mosques or religious institutions.

Primary School Grades: First five grades in school (each of one year) after Kinder Garten.

High School Or Secondary Grades: Five grades in High School after Primary grades.

Apprentices: Persons not in School but receiving vocational training. 


\title{
SUBSCRIPTION RATES \\ for \\ THE PAKISTAN DEVELOPMENT KEVIEW
}

\section{PAKISTAN}

General $\quad \ldots \quad$ Rs. 12.00 per year and

Rs. 3.00 per issue

Students $\quad \ldots \quad$ Rs. 10.00 per year and

Rs. 3.00 per issue

\section{FOREIGN}

\author{
Ammual ‥ U.S. $\$ 4.00$ or \\ U.K. 28 shillings; or \\ equivalent thereof in other currencies \\ Per issue $\quad$... U.S. $\$ 1.00$ or \\ U.K. 7 shillings; or \\ equivalent thereof in other currencies
}

Air postage extra. Payments to be made through bank drafts/postal orders.

All communications should be addressed to :

The Editor,

The Pakistan Development Review,

Pakistan Institute of Development Economics.

Old Sind Assembly Building,

Bunder Road, Karachi-1,

Pakistan. 


\section{PUBLICATIONS OF PAKISTAN INSTITUTE OF DEVELOPMENT ECONCMICS}

Quarterly Journal

The Pakistan Development Review (See inside cover)

Editor: Dr. Bruce Glassburner

Monographs in the Economics of Development (Rs. 5.00 each)

No. 1: A Study of Planning Methodology with Special Reference to Pakistan's Second Five-Year Plan By Dr.J.C.H. Fei and Dr. G. Ranis

No. 2: Towards the Application of Inter-regional Input-Output Models to Economic Planning in Pakistan By S.M. Naseem
B.

No. 3: Deficit Financing in Pakistan, 1951-60

No. 4: A Measure of Inflation in Pakistan, 1951-60
By Monetary and
Fiscal Section By Dr. M. Haq \&

No. 5: Industrial Efficiency and Economic Growth: A Case Study of Karachi

No. 6: Urban Consumer Expenditure and the Consumption Function

No. 7: Problems By Dr. G. Ranis

By'Mrs. N. Sarfraz

No. 8: Wages and Prices in Karachi: A Case Study By A.R. Khan
No. 9: An Analysis of the Long-Run Prospects of Economic Development in Pakistan By Dr.J.C.H. Fei and others
B.

No. 10: Liquidity and Lending: Volume of Bank Credit in Pakistan No. 11: The Pakistan Export Bonus Scheme $\quad \begin{array}{r}\text { By Dr. R.C. Porter } \\ \text { Br. Henry J.Bruton }\end{array}$

No. 12: The Use of Agricultural Surplus Commodities for the Economic Development of Pakistan By Dr. C. Beringer and Irshad Ahmad No. 13: The People of Karachi: Demographic Characteristics

No. 14: The People of Karachi: Social Characteristics

Statistical Papers

By Dr. Sultan S. Hashmi

No. 1: Acreage, Production and Prices of Major Agricultural Crops of West Pakistan (Punjab): 1931-59 (Rs. 5.00)

No. 2: The People of Karachi: Data from A Survey (Rs. 20.00)

Special Publications

By Dr. Sultan S. Hashmi et al.

Social Science Bibliography for Pakistan, 1947-53 (Rs. 5.00) (out of stock)

Report on the Seminar on Industrialization and Labour Management Relations held in Karachi in January 1959 (Rs. 3.00) Editor: M.L. Qureshi A Summary of Selected Studies on Family Planning in Underdeveloped Countries
(Rs. 3.00) (out of stock) By W.P. Mauldin

Population Growth and Economic Development with Special Reference to Pakistan (Rs. 10.00) Editor: M.L. Qureshi

Deficit Financing and Capital Formation: The Pakistan Expereince, 1951-59 (Rs. 5.00) By Pervez Hasan

Partition, Integration, Economic Growth, and Interregional Trade: A Study in the Growth of Interwing Trade in Pakistan (Rs. 7.50)

$B$ B Dr. M. Akhlaqur Rahman
The Economy of Pakistan: A Select Bibliography, 1947-62 (Rs. 5.00) (Rs. 5.00)

A Bibliography of Pakistan Demography (Rs. 3.00)

By A.H. Siddiqui By A.D. Bhatti

Note: Purchasers outside Pakistan should add Re. 1.00 per copy to the price of each publication for mailing and handling charges. Air mail charges extra. 
This work is licensed under a

Creative Commons

Attribution - NonCommercial - NoDerivs 3.0 Licence.

To view a copy of the licence please see:

http://creativecommons.org/licenses/by-nc-nd/3.0/ 